Persistent Chlorinated Compounds and Elements in Tissues of Cook Inlet Beluga Whales, Delphinapterus leucas, Banked by the Alaska Marine Mammal Tissue Archival Project

Paul R. Becker Rebecca S. Pugh Michele M. Schantz Elizabeth A. Mackey Rabia Demiralp Michael S. Epstein Mary Kate Donais Barbara J. Porter

Stephen A. Wise and Barbara A. Mahoney 

NISTIR 6702

Persistent Chlorinated Compounds and Elements in Tissues of Cook Inlet Beluga Whales, Delphinapterus leucas, Banked by the Alaska Marine Mammal Tissue Archival Project

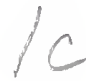

Paul R. Becker

Rebecca S. Pugh

National Institute of Standards and Technology

Chemical Science and Technology Laboratory

Charleston, South Carolina 29412

Michele M. Schantz

Elizabeth A. Mackey

Rabia Demiralp

Michael S. Epstein

Mary Kate Donais

Barbara J. Porter

Stephen A. Wise

National Institute of Standards and Technology

Chemical Science and Technology Laboratory

Gaithersburg, Maryland 20899

Barbara A. Mahoney

National Oceanic and Atmospheric Administration

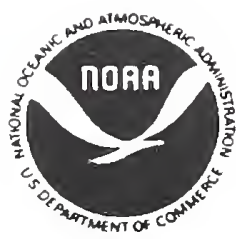

National Marine Fisheries Service

Western Alaska Field Office Anchorage, Alaska 99513

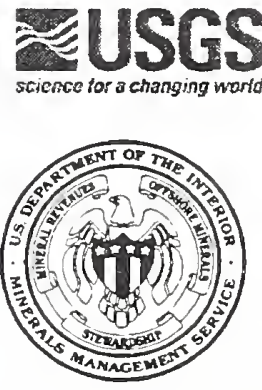

April 2001

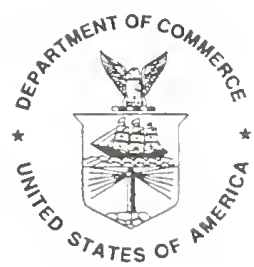

U.S. Department of Commerce Donald L. Evans, Secretary

National Institute of Standards and Technology Karen H. Brown, Acting Director 


\section{PREFACE}

This report is the fourth NIST Interagency Report (IR) that has been published on analytical data generated by the Analytical Chemistry Division, Chemical Science and Technology Laboratory, of NIST on marine mammal tissue specimens archived in the National Biomonitoring Specimen Bank (NBSB). Previous IRs in this series have presented analytical data on northern fur seals, ringed seals, and beluga whales (NISTIR 4731, 1992); ringed seals, spotted seals, bearded seals, beluga whales, and bowhead whales (NISTIR 5620, 1995); and pilot whales, harbor porpoises, and white-sided dolphins (NISTIR 6279, 1999). Much of the data contained in this report, as well as the other IRs cited above, have been or soon will be published in scientific journals. However, through the NISTIR series, the complete analytical database and the detailed methodologies used in sample preparations and analyses are made available to the scientific community.

An additional IR presenting the results of NIST analyses of rough-toothed dolphin tissue specimens banked by the NBSB is currently in preparation. 


\section{CONTENTS}

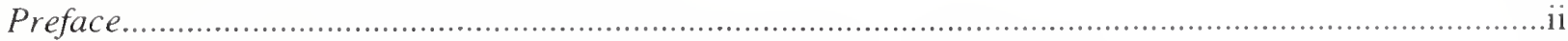

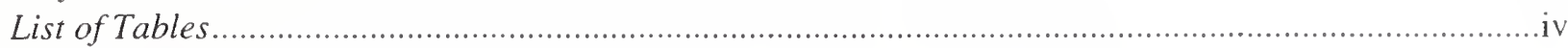

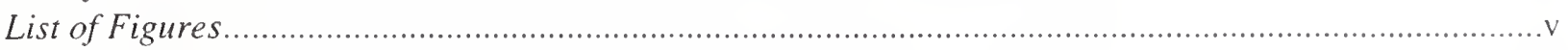

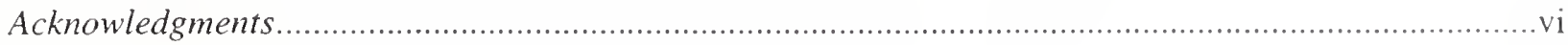

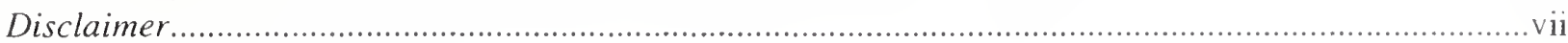

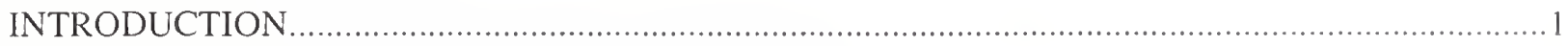

The Alaska Marine Mammal Tissue Archival Project

and the National Marine Mammal Tissue Bank...................................................................... 1

The Beluga Whale, Delphinapterus leucas ......................................................................... 2

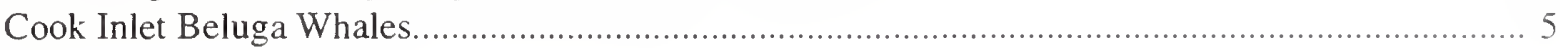

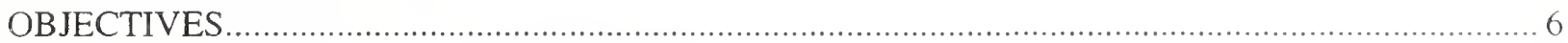

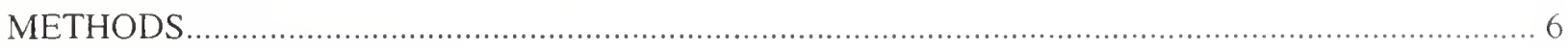

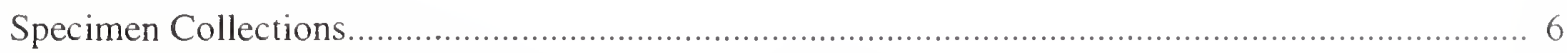

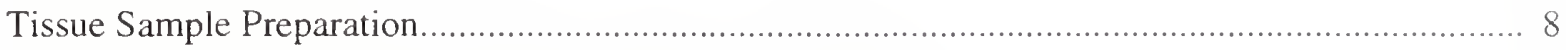

Analysis for Persistent Chlorinated Compounds in Blubber.............................................. 8

Analysis for Elements in Livers and Kidneys ............................................................. 8

Analysis for Methylmercury in Livers and Kidneys........................................................ 9

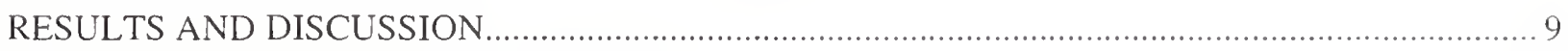

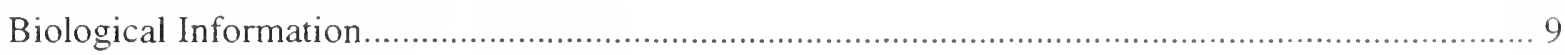

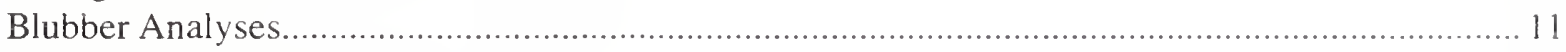

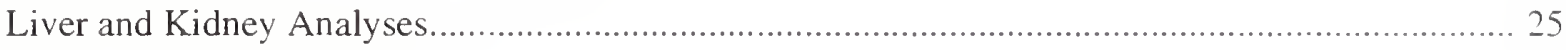

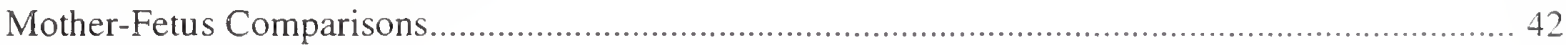

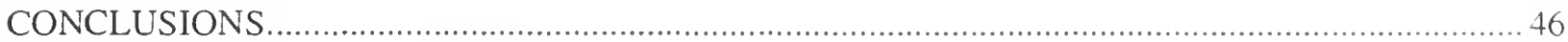

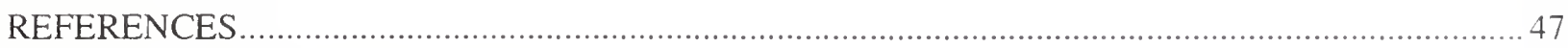

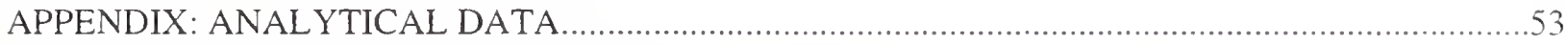

Table A. Concentrations (ng/g wet mass) of PCB Congeners in Blubber of Cook Inlet Beluga Whales................................................................................ 55

Table B. Concentrations (ng/g wet mass) of Chlorinated Pesticides in Blubber of Cook Inlet Beluga Whales................................................................................... 57

Table C. Concentrations ( $\mathrm{mg} / \mathrm{kg}$ wet mass) of Elements in Livers and Kidneys of Cook Inlet Beluga Whales..........................................................................................5

Table D. Ratios of Dry to Wet Mass in Livers and Kidneys of Cook Inlet Beluga Whales......... 67 


\section{LIST OF TABLES}

page

1. Cook Inlet beluga whale tissues analyzed for persistent chlorinated compounds and elements 10

2. Concentrations of PCB congeners in blubber of Alaska beluga whales 13

3. Concentrations of DDT and related compounds in blubber of Alaska beluga whales 15

4. Ratios of DDE/ $\mathrm{DDDT}$ concentrations in blubber of North American populations and stocks of beluga whales

5. Concentrations of chlordane compounds in blubber of Alaska beluga whales.

6. Concentrations of $\mathrm{HCB}, \alpha-\mathrm{HCH}$, dieldrin, and mirex in blubber of Alaska beluga whales.

7. Concentrations of selected elements in livers and kidneys of Cook Inlet beluga whales 26

8. Concentrations of elements in livers of Alaska beluga whales.

9. Concentrations of selected elements in livers and kidneys of a female beluga whale from Cook Inlet and her near-term fetus. 


\section{LIST OF FIGURES}

1. Geographical distribution of the beluga whale, Delphinapterus leucas.

2. Collection locations for beluga whale tissue specimens banked in the National Marine

Mammal Tissue Bank

3. Sampling locations for North American belugas.

4. Concentration of $\Sigma D D T$ in blubber of Cook Inlet beluga whales compared to concentrations reported in blubber of other North American populations and stocks of this species

5. Concentration of trans-nonachlor in blubber of Cook Inlet beluga whales compared to concentrations reported in blubber of other North American populations and stocks of this species

6. Concentration of HCB in blubber of Cook Inlet beluga whales compared to concentrations reported in blubber of other North American populations and stocks of this species

7. Concentration of dieldrin in blubber of Cook Inlet beluga whales compared to concentrations reported in blubber of other North American populations and stocks of this species

8. Concentration of mirex in blubber of Cook Inlet beluga whales compared to concentrations reported in blubber of other North American populations and stocks of this species.

9. Concentration of total mercury in liver tissue of Cook Inlet beluga whales compared to concentrations reported in livers of other North American populations and stocks of this species.

10. Concentration of selenium in liver tissue of Cook Inlet beluga whales compared to concentrations reported in livers of other North American populations and stocks of this species.

11. Concentration of cadmium in liver tissue of Cook Inlet beluga whales compared to concentrations reported in livers of other North American populations and stocks of this species.

12. Concentration of copper in liver tissue of Cook Inlet beluga whales compared to concentrations reported in livers of other North American populations and stocks of this species.

13. Concentration of zinc in liver tissue of Cook Inlet beluga whales compared to concentrations reported in livers of other North American populations and stocks of this species.

14. Mercury in liver tissue of belugas whales

15. Mercury, selenium, and silver concentrations in livers of beluga whales compared to values for other marine mammal species with liver tissue banked in the NMMTB

16. Concentration of vanadium in marine mammal livers.

17. Concentrations of PCB congeners in blubber of a female beluga whale from Cook Inlet and her near-term fetus.

18. Concentrations of chlorinated pesticides in blubber of a female beluga whale from

Cook Inlet and her near-term fetus. 


\section{ACKNOWLEDGMENTS}

The Alaska Marine Mammal Tissue Archival Project is funded by the U.S. Geological Survey Biological Resources Division (USGS/BRD), through sponsorship by the Minerals Management Service (MMS), and is conducted as a collaboration between USGS/BRD, the National Institute of Standards and Technology (NIST), and the National Marine Fisheries Service, Office of Protected Resources (NMFS/OPR). The work presented in this report was also supported by the Marine Mammal Health and Stranding Response Program of NMFS/OPR and the Alaska Beluga Whale Committee (ABWC). Tissue specimens were collected with the cooperation of the Cook Inlet Beluga Whale hunters. The authors would also like to thank Robert Suydam, North Slope Borough Department of Wildlife Management, who provided advice and assistance in determining the beluga whale ages and who was instrumental in gaining $\mathrm{ABWC}$ support for the analyses of Cook Inlet beluga whale specimens. 


\section{DISCLAIMER}

Certain commercial equipment or instruments are identified in this report to specify adequately the experimental procedures. Such identification does not imply recommendations or endorsement by the National Institute of Standards and Technology nor does it imply that the equipment or instruments are the best available for the purpose. 


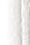




\title{
Persistent Chlorinated Compounds and Elements in Tissues of Cook Inlet Beluga Whales, Delphinapterus leucas, Banked By THE AlaSka Marine Mammal Tissue archival Project
}

\author{
INTRODUCTION
}

\author{
The Alaska Marine Mammal Tissue Arcinval Project \\ and the National Marine Mammal Tissue Bank
}

Environmental specimen banking provides a systematic, well documented, and carefully preserved series of environmental specimens. Specimen banking enables future investigators to extend their research into the past, thereby increasing their time-line of study. Banking also provides specimens that may be used for future verification of analytical results, thus contributing to the quality assurance of environmental monitoring data. Over the last two decades, environmental specimen banking has gained international recognition as an important component of long-term environmental monitoring and research (lyengar and Subramanian, 1997). The U.S. National Biomonitoring Specimen Bank (NBSB) was developed by and is maintained at the National Institute of Standards and Technology (NIST), Gaithersburg, Maryland. The NBSB currently provides for the long-term storage of well-documented and preserved specimens that represent several different types of environmental matrices (Wise and Koster. 1995). The largest portion of the NBSB inventory comes from the marine ecosystem and a very important part of this inventory consists of tissue specimens collected from marine mammals (Becker et al., 1997b).

The National Marine Mammal Tissue Bank (NMMTB), which was established by federal legislation in 1992 (PL 102-587), is maintained by NIST as part of the NBSB. The sources of banked specimens include those collected from animals taken by Alaska Native subsistence hunters, animals caught accidentally in fishing operations, and animals that strand along the coast of the United States. Marine mammal tissue specimens are collected for the NMMTB through the Marine Mammal Health and Stranding Response Program (MMHSRP) of the National Marine Fisheries Service (NMFS) and through the Alaska Marine Mammal Tissue Archival Project (AMMTAP) of the U.S. Geological Survey (USGS) and Minerals Management Service (MMS). Both the MMHSRP and AMMTAP have been previously described in detail (Becker et al.. 1988; 1991; 1993; 1994; Lillestolen et al., 1993).

The principal part of the NMMTB is located at NIST, Gaithersburg, Maryland, and a satellite facility is located at NIST, Charleston, South Carolina. Marine mammal specimens are collected and banked through collaboration with several agencies, laboratories, and local organizations throughout the United States, including: the USGS, Alaska Biological Science Center (Anchorage, Alaska); the U.S. Fish and Wildlife Service, Alaska Biological Science Center (Anchorage, Alaska); the NMFS Western Alaska Field Office (Anchorage, Alaska); the NMFS Alaska Regional Office (Juneau, Alaska); the New England Aquarium (Boston, Massachusetts); the Marine Mammal Center (Sausalito, California); the University of North Carolina (Wilmington, North Carolina); the National Ocean Service, Center for Coastal Environmental Health and Biomolecular Research (Charleston, South Carolina); the North Slope Borough Department of Wildlife Management (Barrow, Alaska); the Eskimo Walrus Commission; and the Natural Resources Division of Kawerak, Inc. (Nome, Alaska).

The beluga or northern white whale, Delphinapterus leucas, is one of the species for which tissue specimens have been archived in the NMMTB. Of the five Alaska stocks of this species (O'Correy-Crowe et al., 1997), banked specimens have been collected by the AMMTAP from the Beaufort Sea, Eastern Chukchi Sea, and 
Cook Inlet stocks. NIST has published its analytical data on the persistent chlorinated compounds and elements in the tissues of the first two stocks through its NISTIR series (Becker et al., 1992; 1995b). Although some of the NIST generated analytical data on the Cook Inlet Beluga whales have been used in recently published journal papers (Becker et al., 1997a; Krahn et al., 1999; Becker et al., in press), not all of the NIST data on these animals have been published. It is therefore the intent of this NISTIR to report and discuss all of the analytical data generated by NIST on selected samples of blubber, liver, and kidney tissue banked from the Cook Inlet beluga whales.

\section{The Beluga Whale, Delphinapterus leucas}

The distribution and movement patterns of the beluga whale are complex. In general, these cetaceans are widely, but not uniformly, distributed throughout most areas of seasonally ice-covered waters in the Arctic and sub-Arctic regions (Fig. 1). They generally spend winters in ice-covered waters, offshore, and in the spring, when the ice starts to break apart, they move toward the coast (Seaman et al., 1986). During the summer months, many whales may migrate long distances between distinct summering locations, concentrating in warmer waters such as estuaries and other open water areas. From late summer to late fall, they move away from the coast, ahead of the advancing pack ice. In the eastern hemisphere belugas are observed regularly in the White, Barents, Kara, Laptev, East Siberian, and Okhotsk seas and occasionally have been sighted off the coasts of Norway. Holland, Denmark, and West Germany (Kleinenberg et al., 1964). Belugas also commonly occur throughout the north Atlantic and eastern Canadian Arctic north to near Ellesmere Island, western Greenland, and Spitsbergen and south to the Gulf of Saint Lawrence (Seaman et al., 1986). The western populations can be found in the Beaufort Sea, Amundsen Gulf, and M'Clure Strait, and westward to the East Siberian Sea (Kleinenberg et al., 1964). They are also observed in the Chukchi, Okhotsk, and Bering seas but are apparently separated from those to the east by heavy pack ice (Seaman et al., 1986).

The beluga whale is the only species of the genus Delphinapterus. It, along with the narwhal, Monodon monoceros, constitute the family, Monodontidae. There are two primary distinctive external distinguishing characteristics of the beluga whale. The first is that this species does not possess a dorsal fin but instead has a dorsal ridge along its back that is often accentuated in older males. This ridge usually rises midway along the back and is 1 to $3 \mathrm{~cm}$ in height (Brodie, 1989). The second distinguishing characteristic is the body color. At birth, the whales are a dark gray and, on occasion, have a brownish-red tint. This color fades and turns to blue-gray as they become juveniles and, as adults (five to six years old), their coloring becomes pure white. This color implies sexual maturity in both the male and female but not necessarily social maturity (actually breeding) for the male (Brodie, 1989).

Beluga whales are very social animals and often travel in large pods, consisting of 15 to $1000+$ animals in a group. Brodie (1989) reported that these large pods are divided into what might be considered nursery groups of several adult females, their newborn, and one or more older calves. The mature males form separate pods of 8 to 16 individuals. In the Soviet Arctic, large all-male aggregations have been observed with numbers ranging from 9 to 500 mature individuals, as well as mixed aggregations in smaller groups of females, with 1 to 3 calves (Brodie, 1989). Along with the gregarious social behavior, beluga whales are highly vocal.

Beluga whales generally have stocky, robust body shapes and highly flexible necks. The neck vertebrae are not fused together, which allows the head to move with relative freedom. The head is small and rounded with a prominent melon and a short beak. The adult male averages $4.0 \mathrm{~m}$ in length but can be as long as 5.7 $\mathrm{m}$. The average weight of the male is $1,500 \mathrm{~kg}$ while that of the female is smaller, averaging $1,360 \mathrm{~kg}$. Females are also shorter in length, averaging $3.7 \mathrm{~m}$. Males reach sexual maturity at five to eight years and 


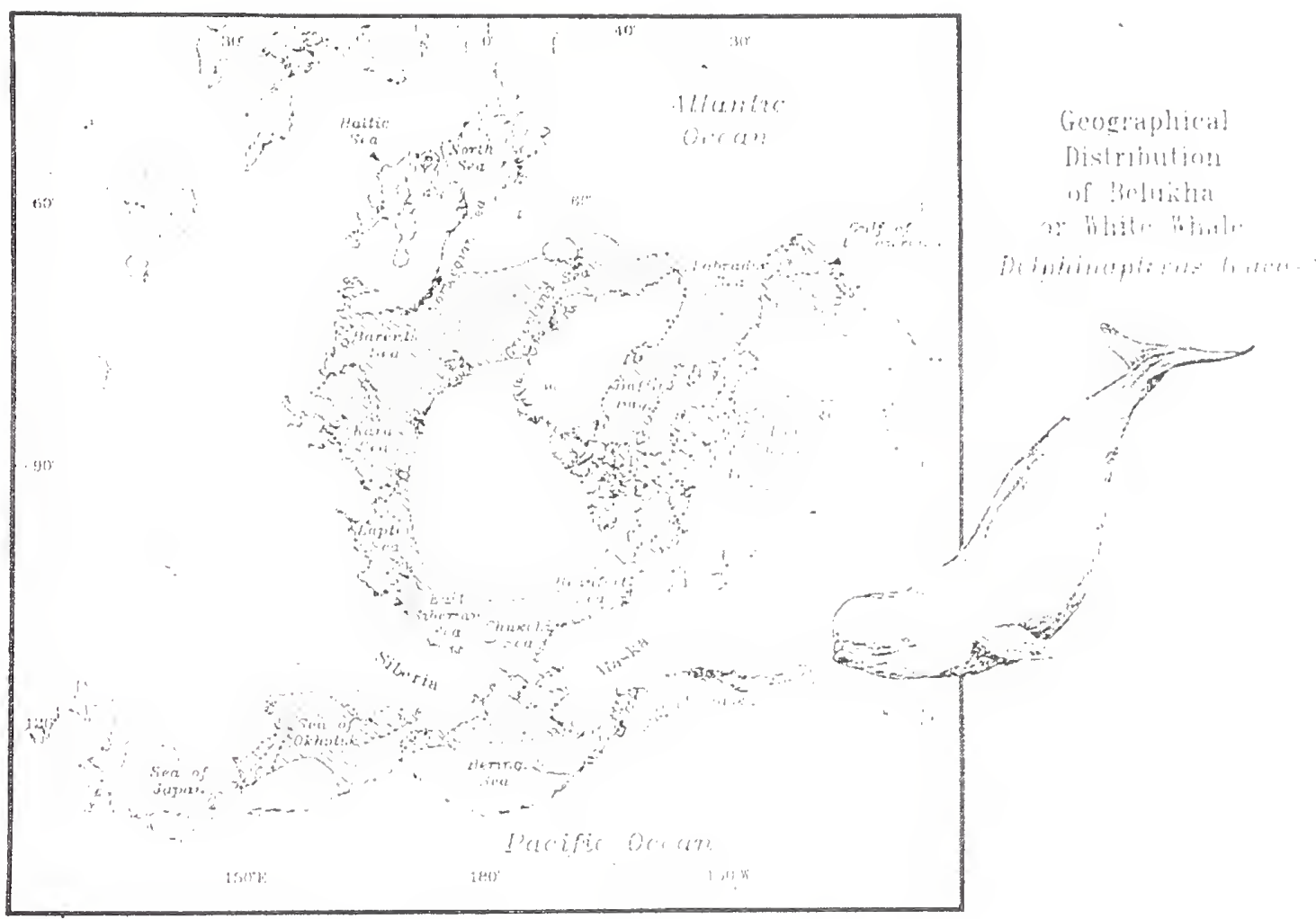

Figure 1. Geographic distribution of the beluga whale. Delphinapterus leucas (courtesy of Point Stevens Press, Auke Bay, Alaska). 
females at age four to seven years. Generally they breed during the spring or early summer but this may vary among populations. Females give birth to a single calf every two or three years after a gestation period of 14 months. At birth, calves measure $1.2 \mathrm{~m}$ to $1.5 \mathrm{~m}$ in length and weigh around $45 \mathrm{~kg}$. Adult females will lactate for one to two years, with the calf completely dependent on nursing during the first year.

Beluga whales are opportunistic feeders, with a diet that includes a large variety of fish, squid, crangonid shrimp, octopus, crabs, and clams (Calkins, 1983; Seaman et al., 1986). This diverse diet reflects the belugas' wide range of habitat, their adaptation to arctic regions of relatively low annual productivity, and their strict seasonality (Brodie, 1989). This species feeds at the top of the marine food web and is exposed to chemicals that accumulate and are biomagnified in the food chain (e.g., mercury, polychlorinated biphenyls [PCBs], etc.). Therefore, the beluga whale has the potential to have relatively high concentrations of persistent contaminants in its tissues. The beluga whale is relatively long-lived $(>35 \mathrm{y})$ and maintains a thick layer of lipid-rich blubber, thus providing a storage depot for the accumulation of lipophilic contaminants (e.g., PCBs and chlorinated pesticides). For all animals, persistent organic contaminants are lipophilic (tending to associate with lipids) and accumulate in body fat. Mammals have various physiological mechanisms for metabolizing and excreting these compounds, the efficacy of which varies among species and varies depending on the chemical characteristics of the individual compounds. Although mechanisms for ridding the body of these compounds are available, the processes are usually slow and the tendency is for the materials to accumulate in body fat over time. The beluga whale is common in nearshore coastal waters and is commonly found several kilometers up major river systems. Due to this behavior, this species has the potential for being exposed to coastal anthropogenic contaminants.

An important source of exposure to consider for beluga whales and for all biota in the higher latitudes is the apparently pervasive release of persistent contaminants in lower latitudes and their transport to remote areas. Numerous studies have documented global contamination by persistent organic contaminants and the role that atmospheric transport plays in the movement of such compounds from lower to higher latitudes (Barrie et al., 1992; Iwata et al., 1994; Tanabe et al., 1994; Wania and Mackay, 1993). Ocean currents probably also play a role, particularly for transport in ice-covered seas and for those compounds that are relatively hydrophilic (e.g., HCH and toxaphene). It is generally accepted that, except for localized "hot spots" of anthropogenic contamination, the concentrations of anthropogenic contaminants reported for tissues of North American Arctic marine mammals probably originate from lower latitudes.

Another concern for marine mammals is the continuous exposure to potentially toxic heavy metals and metalloids (i.e., mercury, cadmium, copper, lead, zinc, and arsenic). These elements occur naturally in the earth's crust and the oceans but many also have anthropogenic origins from local sources of pollution or from global contamination from the atmospheric distribution of pollution (Ponce, 1997). Trace metals may also bioaccumulate in the tissues of these animals and many, such as mercury and cadmium, can be toxic.

The literature on persistent chlorinated compounds and elements in beluga whales is geographically limited. Studies in the Canadian Arctic waters have provided the best data available but even that is minimal (Muir et al., 1990; 1999; Stern et al., 1994; Wagemann et al., 1990; 1996). In addition, there have been a few studies of heavy metals in belugas in Greenland (Dietz et al.,1990; Hansen et al., 1990) and there are no known data available for beluga populations in Russian waters. There have been a few recent published papers on persistent chlorinated compounds and heavy metals in Alaska beluga whales (Becker et al., 1995a; Mackey et al., 1996; Wade et al, 1997; Krahn et al., 1999; Becker et al., in press). This report includes the Beaufort Sea and Eastern Chukchi Sea stocks as well as Cook Inlet animals. 


\section{COOK INLET BELUGA WhaLES}

Some beluga whale stocks are distinct, genetically separate populations (e.g., St. Lawrence River Estuary population in eastern Canada; Cook Inlet population in Alaska), while for many other groups the degree of population separation is questionable. Based on the previous suggestions by Frost and Lowry (1990) and recent genetic evidence by O'Corry-Crowe et al. (1997), there appear to be two populations in Alaska (Cook Inlet and Bering Sea) containing five beluga whale stocks. The Cook Inlet stock represents a geographically isolated, subarctic population of this species. The remaining four Alaska stocks, comprising the Bering Sea population, are the Bristol Bay, Norton Sound. Eastern Chukchi Sea, and Beaufort Sea stocks. The Beaufort Sea stock is thought to include the animals that migrate with bowhead whales, Balaena mysticetus, during the latter's spring migration, and that spend the summer at the mouth of the Mackenzie River and Amundsen Gulf (eastern Beaufort Sea). The Eastern Chukchi Sea stock includes animals of Kotzebue Sound as well as those that occur at Kasegaluk Lagoon (Point Lay) during the summer. The majority of the Bering Sea population appears to spend the winter in ice free areas of the Bering Sea. while some may overwinter in polynyas of the Bering Strait and Chukchi Sea, and in the Gulf of Anadyr and Bristol Bay (Frost and Lowry, 1990; Hazard, 1988). Although the Cook Inlet beluga whales may be found in Cook Inlet during all seasons, they occasionally appear in the Gulf of Alaska as far east as Yakutat and as far west as the Shelikof Strait (Calkins and Pitcher, 1977; Hubbard et al., 1999). The movement of these animals out of Cook Inlet and into the relatively ice free Gulf of Alaska may occur during conditions of heavy ice in Cook Inlet (Calkins, 1983; Hansen and Hubbard, 1999). It is also believed that these whales follow a seasonal pattern. In the spring they move into upper Cook Inlet and, during late May and June, are observed near the mouths of the Susitna, Lewis, and Beluga rivers. They are found in Turnagain and Knik arms of upper Cook Inlet during August and September, then probably move to the lower part of the Inlet in the winter (Calkins, 1987).

The Bering Sea and Cook Inlet beluga whales are somewhat smaller in body size than other populations of this species. Based on information presented by Calkins (1987) and animals sampled by the AMMTAP (Table 1), adult male beluga whales have lengths ranging between $3 \mathrm{~m}$ and $5 \mathrm{~m}$ and weigh up to $1.200 \mathrm{~kg}$, while adult females measure between $2.5 \mathrm{~m}$ and $4 \mathrm{~m}$ in length and weigh up to $700 \mathrm{~kg}$. Breeding occurs in May and calving in July or August in the Alaska populations. Although little is known about the feeding habits of Cook Inlet beluga whales, in general, Alaska beluga whales feed on both fish and invertebrates, primarily in the upper $10 \mathrm{~m}$ of water (Kleinenberger et al.. 1964).

The beluga whale is an important subsistence food resource across the North American Arctic. In Alaska, approximately 30 coastal villages of the Arctic Ocean and Bering Sea and communities located in Cook Inlet (northern part of the Gulf of Alaska), regularly take this species for food. The beluga whale is hunted primarily for its meat and maktaaq (i.e., skin plus blubber). These products are consumed locally and are frequently distributed to villages that do not have access to this resource.

The Cook Inlet population is the smallest of the Alaska stocks of beluga whales. The Bering Sea population may consist of as many as 50,000 animals. The estimated abundances and trends of the individual stocks of the Bering Sea population have been estimated to be 39,000 and stable or increasing for the Beaufort Sea stock, 3,700 and stable for the Eastern Chukchi Sea stock, 17,000 and stable or increasing for the Eastern Bering Sea stock, and 1,500 and stable for the Bristol Bay Stock (Hill and DeMaster, 1999). The Cook Inlet population appears to be less than 500 animals and declining. Aerial surveys conducted from 1994 to 1998 indicate that the population size may have decreased by a fraction of about $50 \%$, i.e., a decrease from 650 in 1994 to 350 in 1998 (Rugh et al., in press). Comparison of geographic distribution during this period when compared with data from the 1970s suggests that the range of this species in Cook Inlet is also shrinking. There has been a consistent decline in sightings of beluga whales, both in the offshore areas and in the lower Cook Inlet (Moore and DeMaster, in press). 
Beluga whales have been taken by Alaska Native hunters for subsistence in Cook Inlet since prehistoric times and some commercial hunting of this species took place in Cook Inlet during the $20^{\text {th }}$ century. It is estimated that 30 to 70 animals were taken annually for subsistence during 1993 to 1997 (Hill and DeMaster, 1999). These estimates include the number of animals that were struck and lost. Due to the apparent decline in the numbers of Cook Inlet beluga whales, Alaska Native hunters canceled the 1999 Cook Inlet hunt and the Marine Mammal Protection Act was amended to require a cooperative agreement between NMFS and Alaska Native organizations before hunting could resume. Also, in response to petitions from the State of Alaska and several organizations, the NMFS designated in 2000 this population of beluga whales as depleted under the Marine Mammal Protection Act (Federal Register: May 31, 2000, Vol. 65, No. 105).

\section{OBJECTIVES}

Through AMMTAP since 1992, blubber, liver, kidney, and muscle specimens have been collected by the NMFS Western Alaska Field Office from Cook Inlet beluga whales that have stranded in the Inlet or from animals taken by Alaska Native subsistence hunters. These specimens are archived in the NBSB/NMMTB. In addition to Cook Inlet beluga whales, AMMTAP, in collaboration with the North Slope Borough Department of Wildlife Management, has obtained tissue specimens from beluga whales taken in Alaska Native subsistence hunts from Point Hope (Beaufort Sea Stock). Point Lay (Eastern Chukchi Sea Stock), and Barrow (probably the Eastern Chukchi Sea Stock), and have archived these samples in the NBSB/NMMTB (Fig. 2).

Aliquots of some of the Cook Inlet beluga whale specimens that were archived in the NBSB/NMMTB have been analyzed by NIST for persistent organic contaminants (i.e., polychlorinated biphenyls [PCBs] and chlorinated pesticides), inorganic constituents (elements, including heavy metals), and methylmercury. The objectives of this report are to: (1) report the analytical data generated by NIST on the Cook Inlet beluga whales and (2) compare the data on the Cook Inlet belugas with data reported previously by NIST for the Eastern Chukchi Sea and Beaufort Sea stocks, and with data published on other populations and stocks of North American beluga whales (Canada and Greenland).

\section{METHODS}

\section{SPECIMEN COLLECTIONS}

Samples of blubber, liver, and kidney were selected for analyses from aliquots of specimens stored under cryogenic conditions $\left(-120^{\circ} \mathrm{C}\right.$ ) in the National Biomonitoring Specimen Bank at NIST (Wise and Koster, 1995). These specimens were collected from 14 Cook Inlet beluga whales during the years 1992 to 1996 by the National Marine Fisheries Service (NMFS) Western Alaska Field Office in collaboration with local Alaska Native hunters and with the support of the Alaska Beluga Whale Committee and Cook Inlet Marine Mammal Council. Collection procedures followed those standard AMMTAP protocols designed to preserve sample integrity and minimize sample contamination from handling (Becker et al., 1991). The gender of each animal was recorded and standard body measurements made. Standard body measurements included: standard length (rostrum to fluke notch), axillary girth, fluke width, and blubber thickness. Teeth were collected for age determinations based on number of growth layer groups counted in a thin longitudinal section taken from the middle of the mandibular tooth (Burns and Seaman, 1986). The ages were determined by the National Marine Fisheries Service Western Alaska Field Office, Anchorage, Alaska, with advice and assistance from Robert Suydam, North Slope Borough Department of Wildlife Management, Barrow, Alaska. 


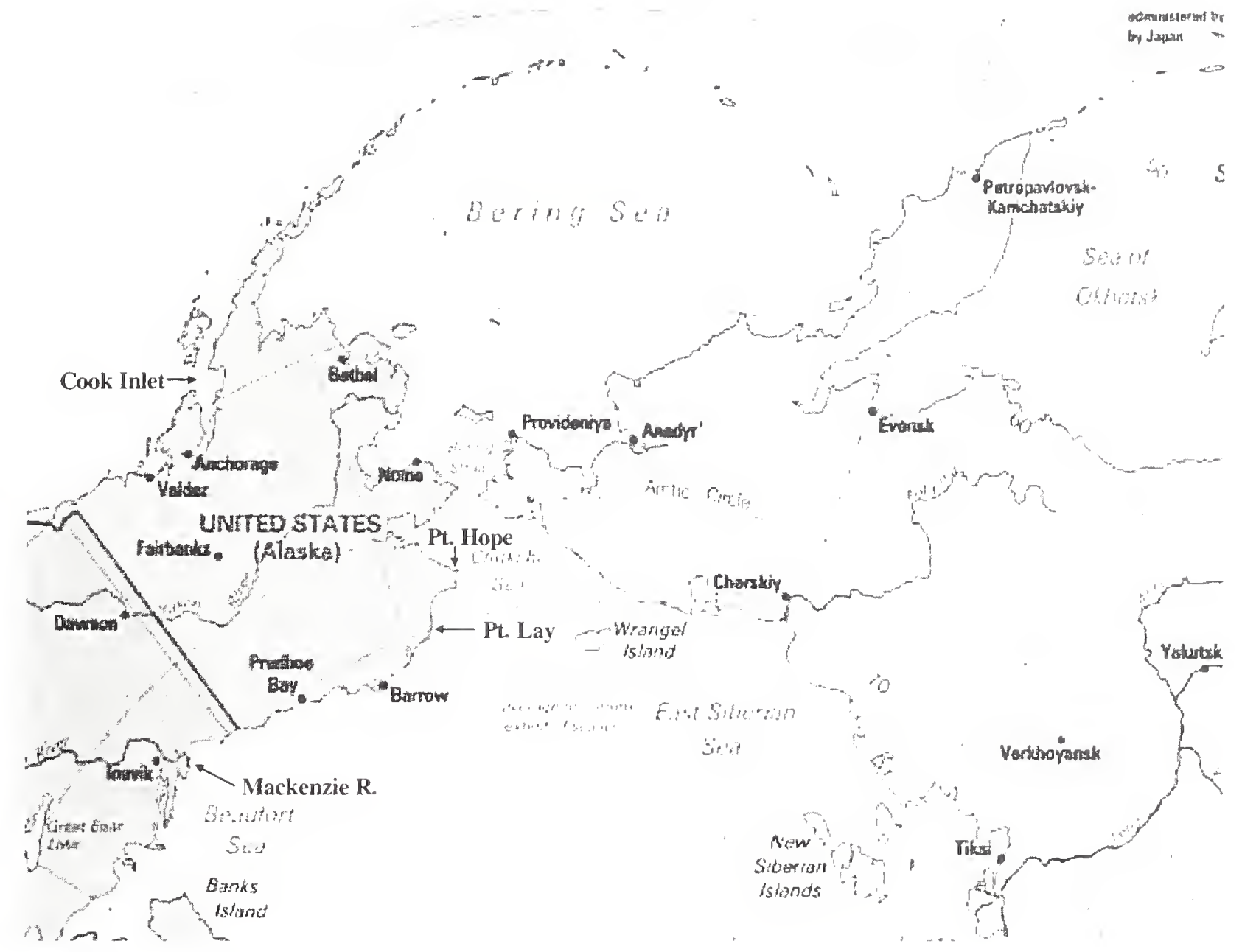

Figure 2. Collection locations (Cook Inlet, Point Hope, Point Lay, and Barrow) for beluga whale tissue specimens banked in the National Marine Mammal Tissue Bank. 


\section{Tissue Sample Preparation}

Each tissue specimen to be analyzed (approximately $150 \mathrm{~g}$, each) was homogenized using a cryogenic procedure designed to reduce the likelihood of changes in sample composition due to thawing and refreezing (Zeisler et al., 1983). Subsamples of the tissue homøgenate, a frozen (not freeze-dried) powder, were aliquoted into Teflon jars $(10 \mathrm{~mL})$ for storage $\left(\mathrm{at}-120^{\circ} \mathrm{C}\right)$ until analyses were performed.

\section{Analysis for Persistent Chlorinated Compoundos in Blubber}

Blubber is routinely analyzed for lipophilic compounds because it is the tissue that commonly has the highest concentrations of these substances. Measurements for determining persistent chlorinated compounds are commonly performed by the Analytical Chemistry Division at NIST. The NIST methodology has been described in detail elsewhere (Becker et al., 1995b; Schantz et al., 1993; 1995). Briefly, the cryogenically homogenized blubber samples ( $2 \mathrm{~g}$ to $3 \mathrm{~g}$ ) were mixed with sodium sulfate and Soxhlet extracted using dichloromethane. The majority of lipids were removed by size exclusion chromatography (SEC), and then polychlorinated biphenyl (PCB) and pesticide fractions were isolated by normal-phase liquid chromatography (LC) on a semi-preparative-scale aminopropylsilane column. The fractions were analyzed by gas chromatography with electron capture detection (GC-ECD) using a $60 \mathrm{~m} \times 0.25 \mathrm{~mm}$ i.d. $5 \%$ mole fraction phenyl methylpolysiloxane capillary column with helium as the carrier gas. The samples that have concentrations reported for both PCB 66 and PCB 95 were also analyzed by GC-ECD using $50 \mathrm{~m} \times 0.25 \mathrm{~mm}$ i.d. $5 \%$ mole fraction phenyl methylpolysiloxane with $10 \%$ mole fraction methyl-C-18 column. NIST SRMs 1588 (Organics in Cod Liver Oil) and 1945 (Organics in Whale Blubber) were analyzed with each set of samples for quality control.

\section{ANAL YSIS FOR ELEMENTS IN LIVERS AND KIDNEYS}

Instrumental neutron activation analysis (INAA) was used by NIST to analyze liver and kidney samples. INAA is a multielement analytical technique that provides data for a large number of trace elements using only a limited amount of the sample. The INAA method is used routinely to measure 37 elements in the NBSB specimens: sodium (Na), magnesium $(\mathrm{Mg})$, aluminum $(\mathrm{Al})$, chlorine $(\mathrm{Cl})$, potassium $(\mathrm{K})$, calcium (Ca), scandium ( $\mathrm{Sc}$ ), vanadium (V), manganese (Mn), iron ( $\mathrm{Fe})$, cobalt (Co), copper ( $\mathrm{Cu}$ ), zinc ( $\mathrm{Zn}$ ), arsenic (As), selenium (Se), bromine (Br), rubidium (Rb), strontium ( $\mathrm{Sr}$ ), molybdenum (Mo), silver (Ag), cadmium (Cd), tin ( $\mathrm{Sn}$ ), antimony (Sb), iodine (I), cesium (Cs), barium (Ba), lanthanum (La), cerium (Ce), samarium $(\mathrm{Sm})$, europium (Eu), terbium ( $\mathrm{Tb}$ ), hafnium (Hf), tantalum (Ta), gold ( $\mathrm{Au})$, mercury (Hg), thorium (Th), and uranium (U).

The INAA method, previously detailed by Mackey et al. (1995, 1996), consists of exposing samples and standards to a neutron field to produce radioactivity and measuring the energy and amount of resulting radiation. In preparation for INAA, subsamples of the frozen powder were lyophilized at a pressure of $1 \mathrm{~Pa}$ for 5 days during which the temperature was gradually increased from $-20^{\circ} \mathrm{C}$ to $5^{\circ} \mathrm{C}$. The dried powder was weighed into two $200 \mathrm{mg}$ aliquots and each aliquot formed into a disk using a commercial stainless steel die and hydraulic press. The disks were packaged individually in acid-washed linear polyethylene (LPE) film. Since $\mathrm{Hg}$ analysis cannot be performed on these packaged disks due to permeation of volatile $\mathrm{Hg}$ into the film during irradiation, two $100 \mathrm{mg}$ aliquots of the powder were placed in acid-washed quartz vials. The vials were flash frozen in liquid nitrogen prior to sealing to avoid any evaporative losses of elemental $\mathrm{Hg}$ or Hg compounds.

Analyses of SRM 1577a Bovine Liver and, beginning in 1991, a QA pilot whale liver tissue homogenate (Wise et al., 1993) were included with all multielement INAA measurements. Analyses of SRM 2710 
Montana Soil and SRM 1571 Orchard Leaves were included with all Hg measurements. For each analysis, aliquots of powdered SRMs were packaged in the same way and are included in the analysis scheme for the purpose of quality control. Standards consisting of known amounts of each element were deposited onto filter papers, and formed into disks to ensure consistent counting geometry between samples, controls, and standards. The irradiation and counting times for INAA were chosen to optimize the number of elements that can be determined and the detection limit for each. All irradiations were done at the NIST Reactor at a reactor power of $20 \mathrm{MW}$, which corresponds to a neutron fluence rate of approximately $2.0 \times 10^{13} \mathrm{~cm}^{-2} \mathrm{~s}^{-1}$.

In addition to INAA, total mercury analysis was performed at NIST using cold vapor atomic absorption spectrometry (CVAAS) following microwave digestion. For this procedure. $0.5 \mathrm{~g}$ of frozen homogenate was placed in a $100 \mathrm{~mL}$ Teflon perfluoroalkoxyalkane (PFA) microwave container and the sample dissolved by microwave digestion using an acid mixture of $4 \mathrm{~mL}$ of $\mathrm{HNO}_{3}, 2 \mathrm{~mL}$ of $\mathrm{HClO}_{4}$, and $0.5 \mathrm{~mL}$ of $\mathrm{HF}$. After digestion and cooling, the sample was transferred to a $30 \mathrm{~mL}$ polypropylene bottle and diluted to a final volume of $25 \mathrm{~mL}$ with high-purity water containing a mass fraction of $1 \% \mathrm{~K}_{2} \mathrm{Cr}_{2} \mathrm{O}_{7}$. The weight and density of the final solutions were used in the calculation of the analyte concentration. The sample was then analyzed by cold vapor generation using a FIAS-200 flow injection system and Perkin-Elmer 5000 AAS. Standards were prepared from a $1,000 \mathrm{mg} / \mathrm{mL}$ stock standard. Two or three separate analysis runs (with a new set of calibration standards prepared for each run) were made for each sample preparation. Two or three separate sample preparations were made for each sample.

\section{ANALYSIS FOR METIIYLMERCURY IN LIVERS AND KIDNEYS}

The methylmercury concentrations in livers and kidneys were determined at NIST using gas chromatography with atomic emission detection (GC-AED) as described by Donais et al. (1996). For this procedure, four methylmercury chloride calibration solutions and one ethyl mercury chloride internal standard solution were prepared gravimetrically in toluene. Subsamples of $0.2 \mathrm{~g}$ to $0.5 \mathrm{~g}$ of frozen homogenates of the liver and kidney samples were extracted in $1 \mathrm{~mL} \mathrm{CuSO}_{4}$ solution ( $16 \mathrm{~g}$ of $\mathrm{CuSO}_{4}$ diluted to $100 \mathrm{~mL}$ with water), 4 $\mathrm{mL}$ acidic $\mathrm{KBr}$ solution ( $18 \mathrm{~g}$ of $\mathrm{KBr}$ and $5 \mathrm{~mL}$ concentrated $\mathrm{H}_{2} \mathrm{SO}_{4}$ diluted to $100 \mathrm{~mL}$ with water with chromatography grade water), and $2 \mathrm{~mL}$ toluene. Approximately $5 \mathrm{~g}$ of activated copper powder was added to each subsample prior to extraction. Following $1 \mathrm{~h}$ of agitation, each sample was centrifuged and the separated toluene layer was removed. The sample was extracted a second time with $2 \mathrm{~mL}$ of toluene (agitation for $10 \mathrm{~min}$ ), the two toluene extractions combined, and the extracts for each sample/standard were spiked with a known mass of internal standard solution. The spiked extract was then concentrated to $0.5 \mathrm{~mL}$ and injected onto a preparative size exclusion chromatography column to remove lipids and biogenic material. One aliquot of each standard solution and one subsample of each tissue were extracted and analyzed by GC-AED in triplicate. NIST Pilot Whale Liver Control Material was analyzed with each set of samples for quality control.

\section{RESULTS AND DISCUSSION}

\section{BIOLOGICAL INFORMATION}

A list of tissues analyzed from the Cook Inlet beluga whales is presented in Table 1, along with gender, age (where determined), standard length, axillary girth, fluke width, blubber thickness, and date sampled for the individual animals. Any unusual appearances of the animals or organs are also noted in the comment column. 


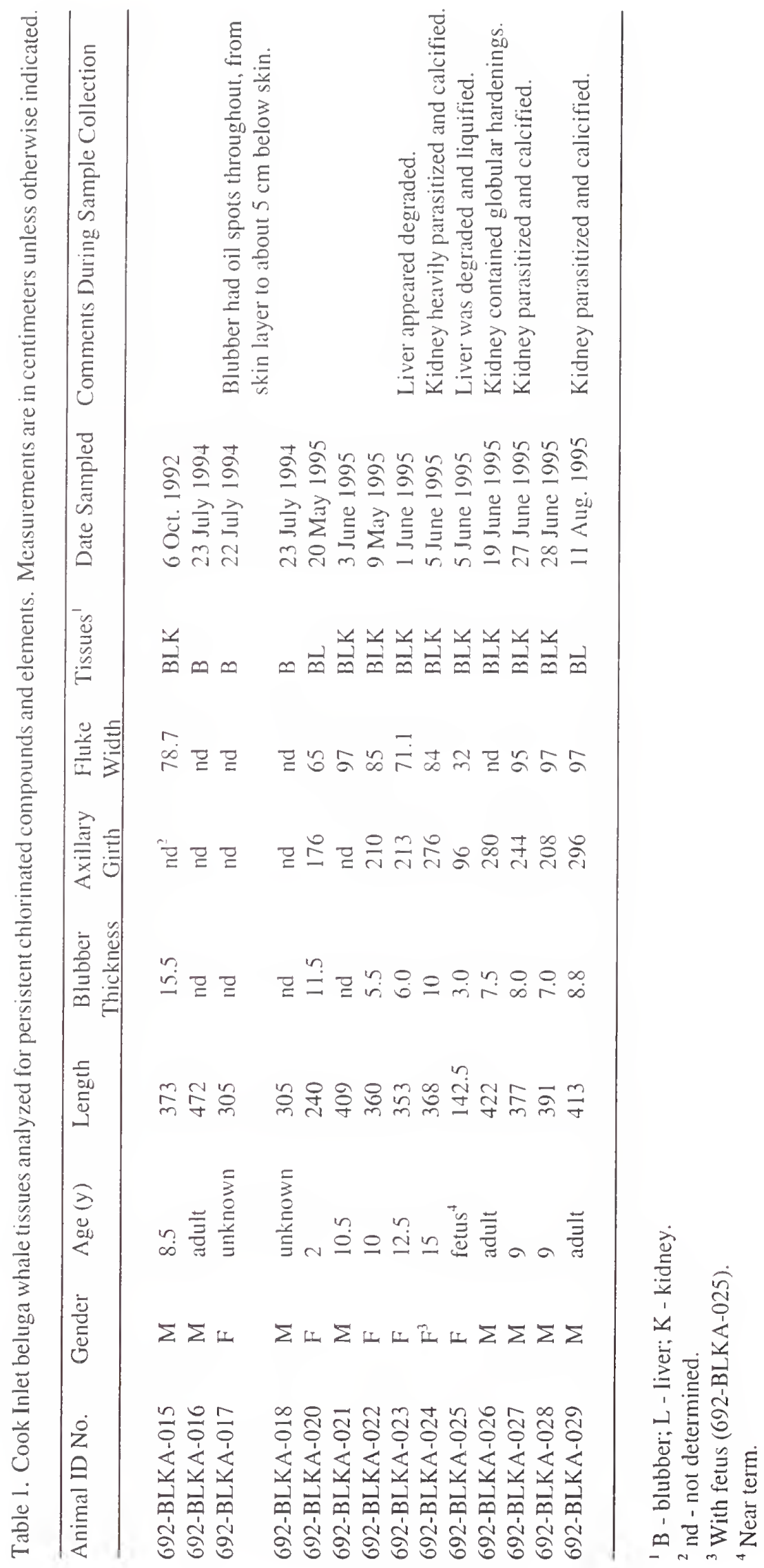


Tissues were analyzed from 4 animals, including a near-term female fetus (692-BLKA-025) collected from animal 692-BLKA-024 (Table 1). These animals were sampled over a three-year period (1992 to 1995), with the majority of the animals (10) sampled in 1995. If a tissue-type is not listed for an individual in Table 1 , this means that particular tissue was not collected and banked from that animal. Blubber was collected from all 14 animals, liver specimens from 11 , and kidney specimens from 9 of the beluga whales.

Of the 14 animals sampled, 8 were males and 6 were females (including the fetus). Excluding the fetus, the length of females ranged from $2.4 \mathrm{~m}$ to $3.7 \mathrm{~m}$ and the length of males from $3 \mathrm{~m}$ to $4.7 \mathrm{~m}$. Blubber thickness ranged from $6 \mathrm{~cm}$ to $15.5 \mathrm{~cm}$, the largest value being from a mature male, 692-BLKA-015, that stranded alive in early October 1992 and subsequently died. This animal had been sampled immediately following death. The live stranding of beluga whales is a common event. The animals move into shallow areas of the upper Cook lnlet to feed on fish returning to or leaving natal streams (the most common prey found in the stomachs of Cook Inlet beluga whales sampled for the NMMTB have been hooligan [Hypomesus pretiosus], eulachon [Thaleichthys pacificus], and salmon [Onchorhynchus spp.]). Due to the extensive mud flats in this area, the extreme tidal range, and the fast-moving incoming and outgoing tides, the beluga whales commonly become trapped on the mud flats. Most survive until the next high tide floats them again; however, a few are less fortunate and succumb before the tidal waters return. Except for this single individual, all of the other animals in Table 1 were taken in local Alaska Native subsistence hunts during the late-spring through summer months (May to August).

In two of the animals, i.e. 692-BLKA-023 and 092-BLKA-025 (the fetus), the livers appeared to be starting to degrade (Table 1). This observation was made based on coloration and texture of the organ. This apparent degradation was probably due to the length of time following the death of these two animals before the liver specimens had been removed. This was most apparent in the fetus, which was to be expected since sampling of this individual occurred after specimens were removed from the mother. Liver tissue degrades more rapidly than either blubber or kidney.

Four of the animals, i.e., 692-BLKA-024 (the pregnant female), 692-BLKA-026, 692-BLKA-027, and 692BLKA-029, had kidneys that were heavily parasitized by the round worm. Crassicauda sp.. as evidenced by cysts (globular hardenings and calcification) and the actual presence of the worms. Parasitism by Crassicauda sp. has been common (40\%) in the kidneys of Cook lnlet beluga whales sampled for the NMMTB.

\section{BLUBber ANALySES}

\section{Polychlorinated Biphenyls (PCBs)}

Data resulting from the analyses of blubber from 13 Cook Inlet beluga whales ( 7 males, 5 females, and 1 female fetus) are presented in the Appendix, Table A, for 31 PCB congeners (i.e., PCBs 18, 31, 28, 52, 49. $44,66 / 95,101,99,87,110 / 77,151,149,118,153,105,138 / 163 / 164,187 / 182,183,156,180,170,195,194$. 206, and 209. Eleven congeners dominated the concentration values for the Cook Inlet beluga whales, i.e., $\mathrm{PCBs} 52,66 / 95,101,99,149,118,153$, and 138/163/164. A summary of the concentration data for these 11 congeners and PCB 105 is presented in Table 2 for Cook Inlet beluga whale males and females (excluding the fetus) and compared with values previously published by NIST for the Point Hope (Beaufort Sea Stock) and Point Lay (Eastern Chukchi Sea Stock) beluga whales (Becker et al., 1995b). PCB 105 is included since it, along with PCB 118, has been found to contribute substantially to the total toxicity of PCB concentrations based on tetrachlorodiphenyl-p-dioxin (TCDD) toxic equivalent calculations (Nakata et al., 1997). PCB 153 occurred in the highest concentrations $(27.7 \mathrm{ng} / \mathrm{g}$ to $249 \mathrm{ng} / \mathrm{g}$ wet mass in the Cook Inlet animals). This congener is not easily metabolized and is usually the dominant PCB congener that occurs in animal tissues. 
For all three beluga whale stocks, concentrations of the PCBs were higher in the male than in the female animals (Table 2). This pattern is reported routinely for marine mammals, since females are able to transfer some of their body loads to the fetus during gestation and to their young through lactation. These avenues for decreasing body loads are not available to the males. Because males tend to have higher concentrations of these compounds in their blubber, their values may be of more concern for human consumption health issues. However, levels in females and their transfer to offspring may be of more concern to the health of the animal population.

The concentrations of PCBs in the blubber of the Cook Inlet beluga whales were lower than concentrations previously published for the Point Hope and Point Lay animals (Table 2). Concentrations of PCB 153 in the Cook Inlet females were half those reported for the two Arctic stocks, and Cook Inlet males had concentrations one-third those of the Point Lay animals. These differences were similar for the other PCB congeners. The biggest difference was found for PCB 118. The concentration levels in the females of the two Arctic stocks were two and a half times higher than females from Cook Inlet and, for males, the Point Lay animals had levels four times higher than the Cook lnlet animals.

The concentrations of PCBs in the blubber of the three stocks of beluga whales are substantially lower than what has been reported from specimens banked from toothed whales from the Atlantic Coast of the U.S. For PCB 153, the concentrations in the Cook Inlet animals ranged from $27.7 \mathrm{ng} / \mathrm{g}$ to $249 \mathrm{ng} / \mathrm{g}$ wet mass and for the two Arctic stocks ranged from $72.6 \mathrm{ng} / \mathrm{g}$ to $539 \mathrm{ng} / \mathrm{g}$. This is in contrast to the blubber of pilot whale, Globicephala melas. and harbor porpoise. Phocoena phocoena. where the values ranged from $246 \mathrm{ng} / \mathrm{g}$ to $2670 \mathrm{ng} / \mathrm{g}$ wet mass and $1747 \mathrm{ng} / \mathrm{g}$ to $5600 \mathrm{ng} / \mathrm{g}$ wet mass, respectively (Becker et al., 1999). The dominant PCB congeners for all three species were the same.

Krahn et al. (1999) and Becker et al. (in press) compared the concentrations of $\Sigma$ PCBs in the blubber of the Cook Inlet beluga whales with similar data from beluga whales from the Beaufort Sea stock, Eastern Chukchi Sea stock, and five additional stocks in Canada, including the St. Lawrence Estuary population (Muir et al., 1990), and one in Greenland (Stern et al., 1994). Sampling locations for these stocks are shown in Figure 3. Among these populations and stocks of beluga whales, the Cook Inlet population had the lowest concentrations and the St. Lawrence Estuary population had the highest PCB concentrations (an order of magnitude higher than the Cook Inlet animals). The St. Lawrence Estuary animals represent the most highly contaminated beluga whales in North America.

\section{Chlorinated Pesticides}

Data resulting from the analyses of blubber from 13 Cook Inlet beluga whales ( 7 males, 5 females, and 1 female fetus) are presented in the Appendix, Table B, for 15 persistent chlorinated pesticides, i.e., dichlorodiphenyltrichloroethane (DDT [2,4'-DDT and 4,4'-DDT]) and its metabolites (2,4'-DDD, 4,4'-DDD, 2,4'-DDE, and 4,4'-DDE), chlordane-related compounds (heptachlor epoxide, cis-chlordane, trans-chlordane, cis-nonachlor, and trans-nonachlor), hexachlorobenzene ( $\mathrm{HCB})$, hexachlorocyclohexane $(\mathrm{HCH})$, dieldrin, and mirex.

A summary of the concentration data for DDT and its metabolites is presented in Table 3 for Cook Inlet beluga whale males and females (excluding the fetus) and compared with values previously published for banked specimens from the Point Hope (Beaufort Sea Stock) and Point Lay (Eastern Chukchi Sea Stock) beluga whales (Becker et al., 1995b). As was the case for the PCBs and as is the case for all the chlorinated pesticides, concentrations on average are higher in the males than in the females. For both males and females, the concentration of DDT compounds in the Cook Inlet animals is much less than has been reported for the Point Hope and Point Lay animals. For example, the average 4,4'-DDE concentrations in the Point Lay animals are twice those of the Cook Inlet animals, for both males and females. The concentrations of 
Table 2. Concentrations of selected PCB congeners in blubber of Alaska beluga whales. Values (ng/g, wet mass) are given as means \pm 1 standard deviation, medians (in parenthesis), and ranges. The values for the Point Hope and Point Lay animals are from Becker et al. (1995b).

\begin{tabular}{|c|c|c|c|c|c|}
\hline \multirow[b]{2}{*}{ Congener } & \multirow{2}{*}{$\begin{array}{c}\text { Point Hope } \\
\text { Females, } n=2\end{array}$} & \multicolumn{2}{|c|}{ Point Lay } & \multicolumn{2}{|c|}{ Cook Inlet } \\
\hline & & Males, $\mathrm{n}=7$ & Females, $\mathrm{n}=3$ & Males, $n=7$ & Females, $\mathrm{n}=5$ \\
\hline 52 & $\begin{array}{l}144 \\
(144) \\
109-179\end{array}$ & $\begin{array}{l}247 \pm 16 \\
(242) \\
225-275\end{array}$ & $\begin{array}{l}112 \pm 110 \\
(89.9) \\
14.1-230\end{array}$ & $\begin{array}{l}86.6 \pm 38.5 \\
(80.2) \\
34.8-146\end{array}$ & $\begin{array}{l}62.3 \pm 28.6 \\
(65.3) \\
21.5-89.9\end{array}$ \\
\hline $66 / 95$ & $\begin{array}{l}148 \\
(148) \\
111-184\end{array}$ & $\begin{array}{l}300 \pm 35 \\
(296) \\
253-355\end{array}$ & $\begin{array}{l}137 \pm 114 \\
(127) \\
27.7-256\end{array}$ & $\begin{array}{l}88.0 \pm 40.9 \\
(77.6) \\
36.2-152\end{array}$ & $\begin{array}{l}72.0 \pm 28.1 \\
(85.4) \\
25.6-92\end{array}$ \\
\hline 99 & $\begin{array}{l}120 \\
(120) \\
99-142\end{array}$ & $\begin{array}{l}245 \pm 36 \\
(246) \\
199-313\end{array}$ & $\begin{array}{l}94.9 \pm 74.9 \\
(79.1) \\
29.1-176\end{array}$ & $\begin{array}{l}59.3 \pm 34.5 \\
(53.1) \\
13.0-107\end{array}$ & $\begin{array}{l}38.8 \pm 22.6 \\
(40.1) \\
5.83-68.8\end{array}$ \\
\hline 101 & $\begin{array}{l}186 \\
(186) \\
145-227\end{array}$ & $\begin{array}{l}334 \pm 35 \\
(337) \\
284-391\end{array}$ & $\begin{array}{l}134 \pm 109 \\
(113) \\
36.3-252\end{array}$ & $\begin{array}{l}122 \pm 65 \\
(103) \\
34.7-222\end{array}$ & $\begin{array}{l}85.5 \pm 41.9 \\
(98.1) \\
20.1-129\end{array}$ \\
\hline 105 & $\begin{array}{l}27.6 \\
(27.6) \\
20.7-34.5\end{array}$ & $\begin{array}{l}61.3 \pm 16.3 \\
(62.1) \\
39.9-88.7\end{array}$ & $\begin{array}{l}26.6 \pm 16.7 \\
(24.1) \\
11.3-44.5\end{array}$ & $\begin{array}{l}21.7 \pm 10.3 \\
(19.3) \\
6.68-37.7\end{array}$ & $\begin{array}{l}14.0 \pm 7.06 \\
(13.8) \\
3.79-23.7\end{array}$ \\
\hline 118 & $\begin{array}{l}96 \\
(96) \\
80-113\end{array}$ & $\begin{array}{l}238 \pm 47 \\
(241) \\
166-307\end{array}$ & $\begin{array}{l}101 \pm 82 \\
(79.3) \\
31.3-192\end{array}$ & $\begin{array}{l}61.1 \pm 30.8 \\
(49.9) \\
20.7-104\end{array}$ & $\begin{array}{l}40.4 \pm 18.0 \\
(38.4) \\
16.1-63.7\end{array}$ \\
\hline $138 / 163 / 164$ & $\begin{array}{l}183 \\
(183) \\
174-192\end{array}$ & $\begin{array}{l}389 \pm 58 \\
(373) \\
300-460\end{array}$ & $\begin{array}{l}179 \pm 148 \\
(145) \\
50.8-342\end{array}$ & $\begin{array}{l}106 \pm 57 \\
(82.9) \\
31.5-181\end{array}$ & $\begin{array}{l}72.6 \pm 33.0 \\
(77.5) \\
23.6-116\end{array}$ \\
\hline 149 & $\begin{array}{l}128 \\
(128) \\
113-142\end{array}$ & $\begin{array}{l}298 \pm 68 \\
(287) \\
209-400\end{array}$ & $\begin{array}{l}124 \pm 93 \\
(85.8) \\
55.7-229\end{array}$ & $\begin{array}{l}96.5 \pm 42.0 \\
(84.2) \\
38.9-148\end{array}$ & $\begin{array}{l}68.4 \pm 24.3 \\
(76.1) \\
32.2-96.5\end{array}$ \\
\hline 153 & $\begin{array}{l}228 \\
(228) \\
220-235\end{array}$ & $\begin{array}{l}462 \pm 70 \\
(467) \\
350-539\end{array}$ & $\begin{array}{l}213 \pm 171 \\
(162) \\
72.6-402\end{array}$ & $\begin{array}{l}144 \pm 77 \\
(114) \\
44.2-249\end{array}$ & $\begin{array}{l}97.9 \pm 47.6 \\
(101) \\
27.7-162\end{array}$ \\
\hline${ }^{\prime} \Sigma \mathrm{PCB}$ & $\begin{array}{l}2370 \\
(2080) \\
2080-2660\end{array}$ & $\begin{array}{l}3459 \pm 522 \\
(3566) \\
2607-4286\end{array}$ & $\begin{array}{l}1492 \pm 1114 \\
(1188) \\
561-2727\end{array}$ & $\begin{array}{l}1137 \pm 564 \\
(982) \\
393-1955\end{array}$ & $\begin{array}{l}818 \pm 345 \\
(926) \\
287-1213\end{array}$ \\
\hline
\end{tabular}

'Sum of PCB 18, 31, 28, 52, 49, 44, 66/95, 99, 101, 87, 110/77, 151, 105, 118, 138/163/164, 149, 153, 187, 183, 156, $180,170,195,194,206$, and 209 


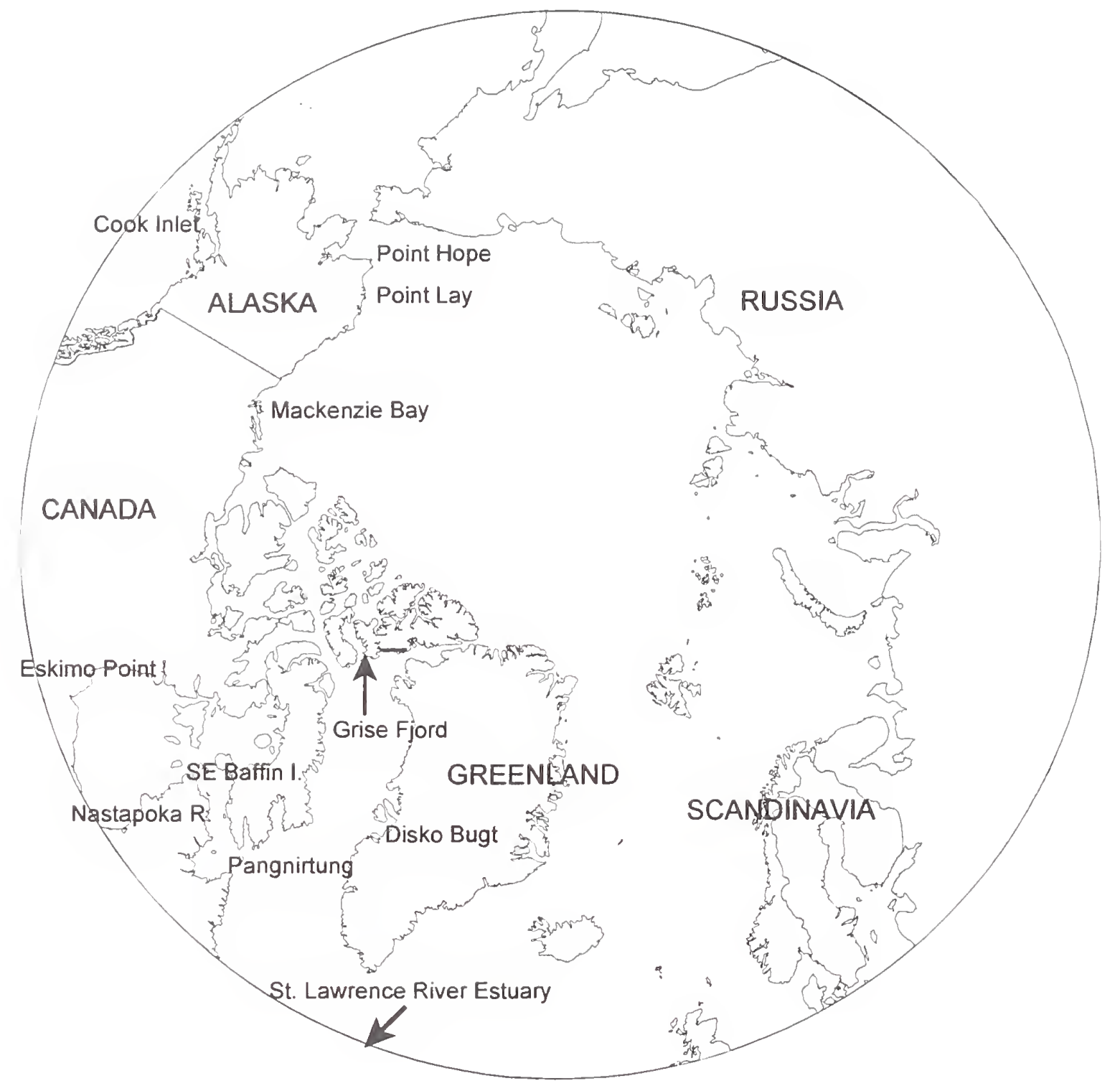

Figure 3. Sampling locations for North American belugas: St. Lawrence River Estuary (off map), Western Greenland (Disko Bugt), Cumberland Sound (Pangnirtung), Eastern Hudson Bay (Nastapoka River), Western Hudson Bay (Eskimo Point \& South East Baffin Island), Jones Sound (Grise Fjord), Beaufort Sea (Mackenzie River \& Point Hope), Eastern Chukchi Sea (Point Lay), and Cook Inlet. 
Table 3. Concentrations of DDT and related compounds in blubber of Alaska beluga whales. Values (ng/g, wet mass) are given as means \pm 1 standard deviation, medians (in parenthesis), and ranges. The values for the Point Hope and Point Lay animals are from Becker et al. (1995b).

\begin{tabular}{|c|c|c|c|c|c|}
\hline \multirow[b]{2}{*}{ Compound } & \multirow{2}{*}{$\begin{array}{c}\text { Point Hope } \\
\text { Females, } n=2\end{array}$} & \multicolumn{2}{|c|}{ Point Lay } & \multicolumn{2}{|c|}{ Cook Inlet } \\
\hline & & Males, $n=7$ & Females, $n=3$ & Males, $n=7$ & Females, $\mathrm{n}=5$ \\
\hline $2,4^{\prime}$-DDT & $\begin{array}{l}252 \\
(252) \\
232-271\end{array}$ & $\begin{array}{l}482 \pm 94 \\
(505) \\
324-600\end{array}$ & $\begin{array}{l}446 \pm 380 \\
(416) \\
81.9-840\end{array}$ & $\begin{array}{l}148 \pm 67 \\
(142) \\
68.2-235\end{array}$ & $\begin{array}{l}120 \pm 53 \\
(129) \\
31.2-165\end{array}$ \\
\hline 4,4'-DDT & $\begin{array}{l}236 \\
(236) \\
209-262\end{array}$ & $\begin{array}{l}584 \pm 148 \\
(586) \\
322-771\end{array}$ & $\begin{array}{l}302 \pm 216 \\
(280) \\
98.4-528\end{array}$ & $\begin{array}{l}193 \pm 94 \\
(162) \\
83.1-306\end{array}$ & $\begin{array}{l}107 \pm 52 \\
(129) \\
29.2-156\end{array}$ \\
\hline 2.4'-DDD & $\begin{array}{l}20.9 \\
(20.9) \\
14.2-27.6\end{array}$ & $\begin{array}{l}55.4 \pm 25.2 \\
(57.7) \\
19.6-88.6\end{array}$ & $\begin{array}{l}34.5 \pm 21.8 \\
(39.6) \\
11.9-54.9\end{array}$ & $\begin{array}{l}26.1 \pm 15.5 \\
(22.2) \\
12.2-58.0\end{array}$ & $\begin{array}{l}14.0 \pm 5.5 \\
(12.2) \\
7.86-21.9\end{array}$ \\
\hline $4,4^{\prime}-\mathrm{DDD}$ & $\begin{array}{l}110 \\
(110) \\
79.2-140\end{array}$ & $\begin{array}{l}211 \pm 27 \\
(216) \\
156-236\end{array}$ & $\begin{array}{l}115 \pm 89 \\
(110) \\
28.4-206\end{array}$ & $\begin{array}{l}136 \pm 79 \\
(112) \\
37.1-273\end{array}$ & $\begin{array}{l}82.7 \pm 43.4 \\
(75.8) \\
25.9-143\end{array}$ \\
\hline 2,4'-DDE & $\begin{array}{l}32.4 \\
(32.4) \\
20.5-44.3\end{array}$ & $\begin{array}{l}29.0 \pm 15.0 \\
(25.2) \\
8.10-52.7\end{array}$ & $\begin{array}{l}8.53 \pm 6.46 \\
(8.90) \\
1.90-14.8\end{array}$ & $\begin{array}{l}27.5 \pm 14.4 \\
(25.7) \\
6.62-49.5\end{array}$ & $\begin{array}{l}14.5 \pm 8.4 \\
(18.9) \\
3.20-21.6\end{array}$ \\
\hline 4,4'-DDE & $\begin{array}{l}647 \\
(647) \\
647-647\end{array}$ & $\begin{array}{l}1881 \pm 363 \\
(1984) \\
1245-2230\end{array}$ & $\begin{array}{l}765 \pm 781 \\
(511.3) \\
142-1640\end{array}$ & $\begin{array}{l}834 \pm 646 \\
(645) \\
137-1800\end{array}$ & $\begin{array}{l}396 \pm 220 \\
(420) \\
65.9-660\end{array}$ \\
\hline$\Sigma D D T$ & $\begin{array}{l}1297 \\
(1297) \\
1202-1392\end{array}$ & $\begin{array}{l}3243 \pm 637 \\
(3405) \\
2087-3816\end{array}$ & $\begin{array}{l}1450 \pm 1309 \\
(1127) \\
332-2890\end{array}$ & $\begin{array}{l}1365 \pm 870 \\
(1177) \\
344-2543\end{array}$ & $\begin{array}{l}734 \pm 352 \\
(767) \\
163-1126\end{array}$ \\
\hline $4,4^{\prime}-\mathrm{DDE} / \Sigma \mathrm{DDT}$ & $\begin{array}{l}0.50 \\
(0.50) \\
0.46-0.54\end{array}$ & $\begin{array}{l}0.58 \pm 0.02 \\
(0.58) \\
0.54-0.92\end{array}$ & $\begin{array}{l}0.48 \pm 0.08 \\
(0.45) \\
0.43-0.57\end{array}$ & $\begin{array}{l}0.56 \pm 0.10 \\
(0.55) \\
0.40-0.71\end{array}$ & $\begin{array}{l}0.51 \pm 0.09 \\
(0.55) \\
0.40-0.59\end{array}$ \\
\hline
\end{tabular}


the EDDT compounds in the Cook Inlet beluga whales are compared to the Point Hope and Point Lay animals and with previously published values for beluga whales from Greenland and Canada in Figure 4 (collection locations are shown in Figure 3). As was the case for $\Sigma$ PCBs, lowest values for $\Sigma$ DDT were found in the Cook Inlet animals.

Both DDD and DDE are metabolites of the parent compound DDT. Although DDD is relatively unstable and is readily metabolized to dichlorodiphenyl acetic acid (DDA), which is water soluble and readily excreted, DDE and particularly 4,4'DDE is relatively stable and tends to persist. Thus, 4,4'DDE tends to occur at higher concentrations in blubber tissues of marine mammals than any of the other DDT-related compounds. In Table 3, 4,4'DDE occurs in higher concentrations in the blubber of all three Alaska stocks than any of the other related compounds. In the Cook Inlet beluga whales, 4.4'DDE occurs at levels about four times higher on average than those for 4,4'-DDT. Aguilar (1984) has suggested that the higher the concentration of 4,4'-DDE compared to the concentration of parent DDT the older (metabolized) the source of the parent DDT. The ratio of 4,4'-DDE/ 2 DDT for both male and female Cook Inlet beluga whales are compared in Table 3 to this ratio for the Point Hope and Point Lay animals. On average for all three stocks, the ratios are very similar, i.e.. 0.51, 0.50, and 0.48 for the Cook Inlet, Point Hope, and Point Lay females, respectively, and 0.56 and 0.58 for the Cook Inlet and Point Lay males, respectively. The range of values was greater in the males than in the females. The ratios of DDE/ $\mathrm{DDT}$ ( $\mathrm{DDE}=2,4^{\prime}-\mathrm{DDE}+4,4^{\prime}-\mathrm{DDE}$ ) have been reported by Stern et al. (1994) for beluga whales from Greenland and Muir et al. (1990) for beluga whales from several stocks in Canada. These ratios are similar to those of the Eastern Chukchi Sea, Beaufort Sea, and Cook Inlet stocks (Table 4), suggesting a similar source for DDT throughout the North American Arctic. In contrast, DDE/ $2 D D T$ ratios for northern fur seals from the open-ocean North Pacific have been reported to be as high as 0.93 (Becker et al., 1995b).

The concentrations of chlordane compounds in the blubber of the Cook Inlet beluga whales are compared to those of the two Arctic stocks of this species in Table 5. Of the four compounds measured, transnonachlor occurred in the highest concentrations and there was substantial contribution from heptachlor epoxide and cis-nonachlor. There was significantly less chlordane in the Cook Inlet animals. On average there was three to four times less trans-nonachlor, three to six times less heptachlor epoxide, and five to eight times less cis-nonachlor in the Cook Inlet beluga whales.

The concentrations of the trans-nonachlor in the blubber of Cook Inlet beluga whales are compared with previously published values for beluga whales from the Alaska Arctic, Greenland, and Canada in Figure 5. The levels in the Cook Inlet females were similar to levels reported from females from Cumberland Sound and Hudson Bay, while concentrations in the Cook Inlet males were much less than values reported for males from Arctic Canada and the St. Lawrence Estuary. These results indicate a much lower contribution from this class of compounds to the total persistent organic contaminant loads in the Cook Inlet beluga whales than in the other stocks and populations of this species. Using the ratio of $\Sigma$ chlordanes/ $\Sigma$ PCBs, Krahn et al. (I999) have indicated that the average contribution of chlordane compounds to the total loads is substantially less in the Cook Inlet animals (0.35) than in the animals from Eastern Beaufort and Chukchi Sea stocks (0.55), more than twice as high as for the St. Lawrence beluga whales (0.1) and about half that for beluga whales from Hudson Bay and Jones Sound (0.8). The differences in these ratios suggest different sources of these compounds, which may be related to geographic and latitudinal differences in atmospheric transport patterns and processes or different feeding habits or prey availability among these stocks.

Comparisons of the concentrations of $\mathrm{HCB}, \alpha-\mathrm{HCH}$, dieldrin, and mirex among the Alaska beluga whales are presented in Table 6. Concentrations of HCB, dieldrin, and mirex among the North American beluga whale stocks are compared in Figures 6 through 8. As was found for the other chlorinated pesticides, concentrations of these compounds were less in the Cook Inlet beluga whales than in the other beluga whale stocks. The difference was most pronounced for dieldrin and mirex. 


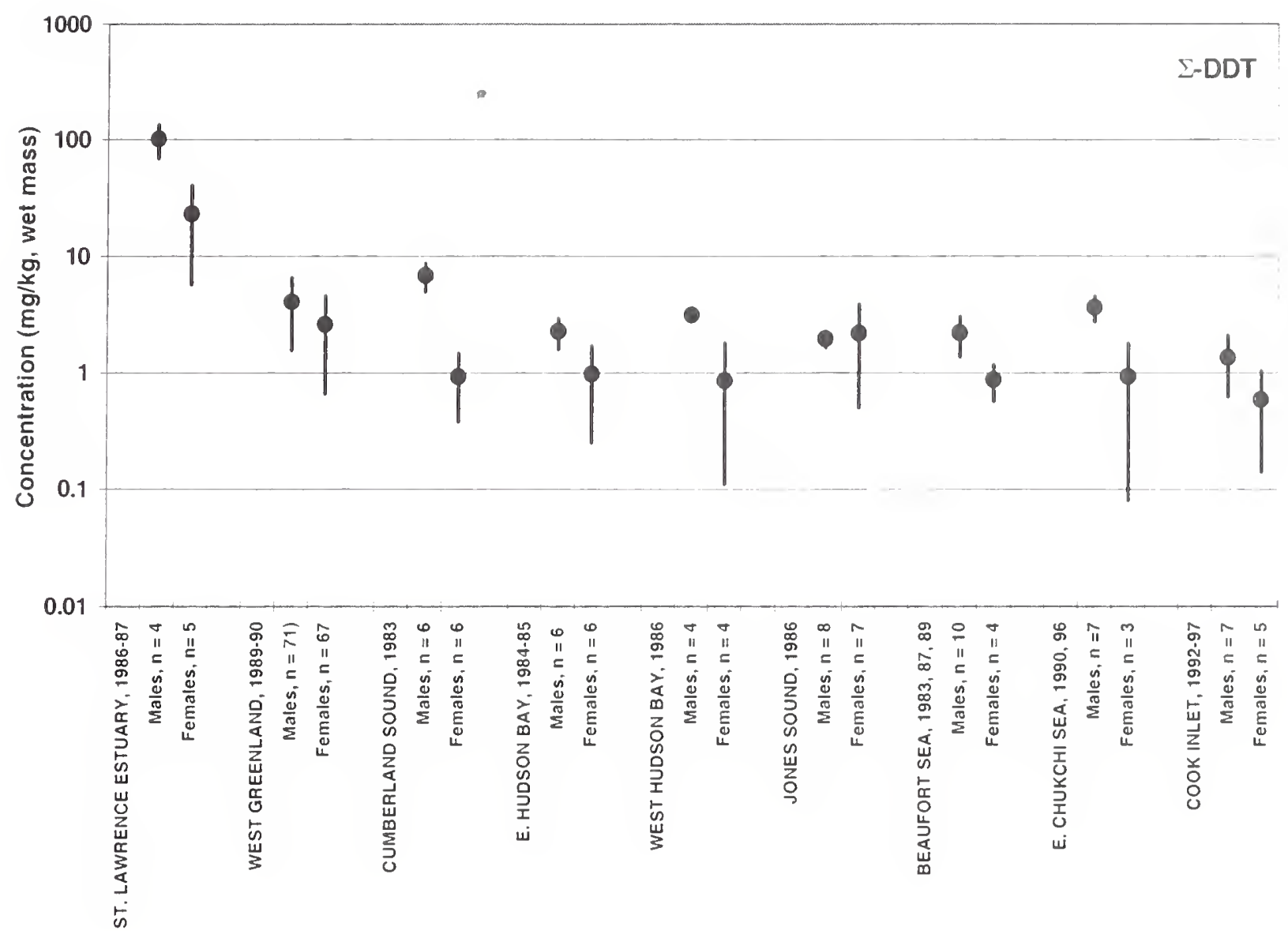

Figure 4. Concentration of EDDT (mean \pm 1 standard deviation) in blubber of Cook Inlet beluga whales compared to concentrations reported in the blubber of other North American populations and stocks of this species. The standard deviation for each mean $(\bullet)$ is indicated by a vertical bar. Geographic locations, dates of sample collections, gender, and number of individuals are shown on the $\underline{X}$ axis. Data are from Becker et al. (1995b), Muir et al. (1990), Stern et al. (1994), and NIST (this report). The Beaufort Sea stock is represented by animals sampled from the Mackenzie River Estuary (Muir et al., 1990) and Point Hope. Alaska (Becker et al.. 1995b). 
Table 4. Ratios of DDE/LDDT concentrations in blubber of North American populations and stocks of beluga whales. DDE is the sum of the concentrations of $2,4^{\prime}-\mathrm{DDE}$ and $4,4^{\prime}$-DDE.

\begin{tabular}{|c|c|c|c|c|}
\hline Location & Sampling date & Sex & $\mathrm{n}$ & $\mathrm{DDE} / \Sigma \mathrm{DDT}$ \\
\hline 'West Greenland, Nuussuaq/ Disko Bugt & $1989-90$ & $\begin{array}{l}\mathrm{M} \\
\mathrm{F}\end{array}$ & $\begin{array}{l}71 \\
67\end{array}$ & $\begin{array}{l}0.56 \pm 0.05 \\
0.52 \pm 0.05\end{array}$ \\
\hline${ }^{2}$ Cumberland Sound, Pangnirtung & 1983 & $\begin{array}{l}\mathrm{M} \\
\mathrm{F}\end{array}$ & $\begin{array}{l}6 \\
6\end{array}$ & $\begin{array}{l}\mathrm{nr} \\
\mathrm{nr}\end{array}$ \\
\hline${ }^{2}$ St. Lawrence Estuary & $1986-87$ & $\begin{array}{l}M \\
F\end{array}$ & $\begin{array}{l}4 \\
5\end{array}$ & $\begin{array}{l}0.66 \pm 0.06 \\
0.56 \pm 0.09\end{array}$ \\
\hline${ }^{2}$ E. Hudson Bay, Nastapoka & 1984-85 & $\begin{array}{l}\mathrm{M} \\
\mathrm{F}\end{array}$ & $\begin{array}{l}6 \\
6\end{array}$ & $\begin{array}{l}\mathrm{nr} \\
\mathrm{nr}\end{array}$ \\
\hline${ }^{2}$ W. Hudson Bay, Eskimo Point & 1986 & $\begin{array}{l}\mathrm{M} \\
\mathrm{F}\end{array}$ & $\begin{array}{l}4 \\
4\end{array}$ & $\begin{array}{l}0.57 \pm 0.04 \\
0.57 \pm 0.04\end{array}$ \\
\hline${ }^{2}$ Jones Sound, Grise Fjord & 1986 & $\begin{array}{l}\mathrm{M} \\
\mathrm{F}\end{array}$ & $\begin{array}{l}8 \\
7\end{array}$ & $\begin{array}{l}0.55 \pm 0.04 \\
0.56 \pm 0.05\end{array}$ \\
\hline${ }^{3}$ Beaufort Sea, Mackenzie R. \& Point Hope, Alaska & $1983.1987,1989$ & $\begin{array}{l}\mathrm{M} \\
\mathrm{F}\end{array}$ & $\begin{array}{r}10 \\
4\end{array}$ & $\begin{array}{l}0.47 \pm 0.15 \\
0.50 \pm 0.06\end{array}$ \\
\hline${ }^{3}$ E. Chukchi Sea, Point Lay, Alaska & 1990,1996 & $\begin{array}{l}\mathrm{M} \\
\mathrm{F}\end{array}$ & $\begin{array}{l}7 \\
3\end{array}$ & $\begin{array}{l}0.59 \pm 0.02 \\
0.49 \pm 0.07\end{array}$ \\
\hline${ }^{4}$ Cook Inlet, Alaska & $1992-97$ & $\begin{array}{l}\mathrm{M} \\
\mathrm{F}\end{array}$ & $\begin{array}{l}7 \\
5\end{array}$ & $\begin{array}{l}0.58 \pm 0.10 \\
0.53 \pm 0.08\end{array}$ \\
\hline
\end{tabular}

${ }^{1}$ Stern et al. (1994)

${ }^{2}$ Muir et al. (19900

${ }^{3}$ Muir et al. (1990 and Becker et al. (1995)

${ }^{4}$ this report

${ }^{5} \mathrm{nr}$ - not reported 
Table 5. Concentrations of chlordane compounds in blubber of Alaska beluga whales. Values (ng/g, wet mass) are given as means \pm 1 standard deviation, medians (in parenthesis), and ranges. The values for the Point Hope and Point Lay animals are from Becker et al. (1995b).

\begin{tabular}{|c|c|c|c|c|c|}
\hline \multirow[b]{2}{*}{ Compound } & \multirow{2}{*}{$\begin{array}{c}\text { Point Hope } \\
\text { Females, } n=2\end{array}$} & \multicolumn{2}{|c|}{ Point Lay } & \multicolumn{2}{|c|}{ Cook Inlet } \\
\hline & & Males, $n=7$ & Females, $\mathrm{n}=3$ & Males, $n=7$ & Females, $n=5$ \\
\hline $\begin{array}{l}\text { Heptachlor } \\
\quad \text { epoxide }\end{array}$ & $\begin{array}{l}72.4 \\
(72.4) \\
59.3-85.5\end{array}$ & $\begin{array}{l}171 \pm 23 \\
(173) \\
144-215\end{array}$ & $\begin{array}{l}95.8 \pm 80.5 \\
(88.1) \\
19.4-180\end{array}$ & $\begin{array}{l}27.1 \pm 35.0 \\
(15.4) \\
1.93-95.0\end{array}$ & $\begin{array}{l}30.5 \pm 25.7 \\
(31.9) \\
2.96-68.5\end{array}$ \\
\hline cis-chlordane & $\begin{array}{l}18.2 \\
(18.2) \\
17.3-19.2\end{array}$ & $\begin{array}{l}45.8 \pm 15.9 \\
(38.8) \\
28.9-74.8\end{array}$ & $\begin{array}{l}29.8 \pm 2.02 \\
(29.0) \\
28.3-32.1\end{array}$ & $\begin{array}{l}22.7 \pm 13.3 \\
(18.3) \\
9.31-50.7\end{array}$ & $\begin{array}{l}15.0 \pm 9.1 \\
(14.9) \\
5.97-29.7\end{array}$ \\
\hline trans-chlordane & $\mathrm{na}^{1}$ & $\begin{array}{l}21.0 \pm 17.2 \\
(12.1) \\
7.80-55.2\end{array}$ & $\begin{array}{l}6.27 \pm 2.27 \\
(7.10) \\
3.70-8.00\end{array}$ & $\begin{array}{l}9.68 \pm 4.25 \\
(10.2) \\
2.99-16.1\end{array}$ & $\begin{array}{l}5.91 \pm 2.87 \\
(5.44) \\
2.71-9.86\end{array}$ \\
\hline cis-nonachlor & $\begin{array}{l}84.5 \\
(84.5) \\
71.0-98.0\end{array}$ & $\begin{array}{l}178 \pm 37 \\
(176) \\
137-232\end{array}$ & $\begin{array}{l}120 \pm 80 \\
(126) \\
37.2-196\end{array}$ & $\begin{array}{l}23.7 \pm 19.6 \\
(14.6) \\
7.90-55.9\end{array}$ & $\begin{array}{l}22.0 \pm 17.4 \\
(15.5) \\
5.95-47.2\end{array}$ \\
\hline trans-nonachlor & $\begin{array}{l}598 \\
(598) \\
544-652\end{array}$ & $\begin{array}{l}1070 \pm 111 \\
(1080) \\
882-1260\end{array}$ & $\begin{array}{l}534 \pm 404 \\
(454) \\
176-971\end{array}$ & $\begin{array}{l}249 \pm 116 \\
(226) \\
69.7-445\end{array}$ & $\begin{array}{l}177 \pm 102 \\
(156) \\
31.5-279\end{array}$ \\
\hline
\end{tabular}

ina - not analyzed 


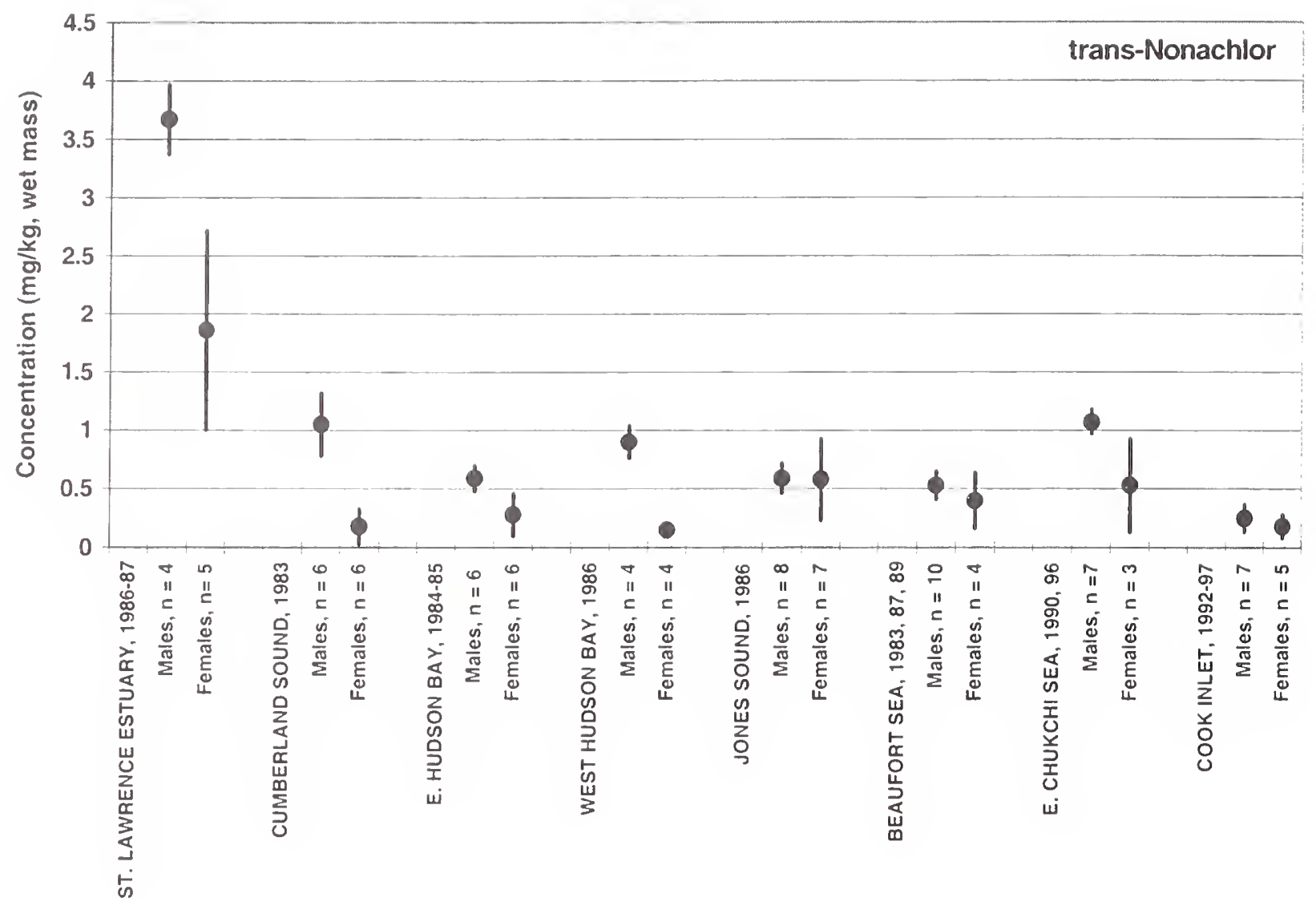

Figure 5. Concentration of trans-nonachlor (mean \pm 1 standard deviation) in blubber of Cook Inlet beluga whales compared to concentrations reported in the blubber of other North American populations and stocks of this species. The standard deviation for each mean $(\bullet)$ is indicated by a vertical bar. Geographic locations, dates of sample collections, gender, and number of individuals are shown on the $\underline{X}$ axis. Data are from Becker et al. (1995b), Muir et al. (1990), and NIST (this report). The Beaufort Sea stock is represented by animals sampled from the Mackenzie River Estuary (Muir et al., I990) and Point Hope, Alaska (Becker et al., 1995b). 
Table 6. Concentrations of HCB, $\alpha$-HCH. dieldrin, and mirex in blubber of Alaska beluga whales. Values (ng/g, wet mass) are given as means \pm 1 standard deviation, medians (in parenthesis), and ranges. The values for the Pount Hope and Point Lay animals are from Becker et al. (1995b).

\begin{tabular}{|c|c|c|c|c|c|}
\hline \multirow[b]{2}{*}{ Compound } & \multirow{2}{*}{$\begin{array}{c}\text { Point Hope } \\
\text { Females, } n=2\end{array}$} & \multicolumn{2}{|c|}{ Point Lay } & \multicolumn{2}{|c|}{ Cook Inlet } \\
\hline & & Males, $n=7$ & Females, $\mathrm{n}=3$ & Males, $\mathrm{n}=7$ & Females, $\mathrm{n}=5$ \\
\hline $\mathrm{HCB}$ & $\begin{array}{l}306 \\
(306) \\
257-354\end{array}$ & $\begin{array}{l}821 \pm 84 \\
(792) \\
738-952\end{array}$ & $\begin{array}{l}446 \pm 380 \\
(416) \\
81.9-840\end{array}$ & $\begin{array}{l}228 \pm 115 \\
(224) \\
78-412\end{array}$ & $\begin{array}{l}289 \pm 262 \\
(203) \\
69.0-741\end{array}$ \\
\hline$\alpha-\mathrm{HCH}$ & $\begin{array}{l}171 \\
(171) \\
162-180\end{array}$ & $\begin{array}{l}117 \pm 46 \\
(101) \\
70.8-196\end{array}$ & $\begin{array}{l}112 \pm 72 \\
(104) \\
43.9-187\end{array}$ & $\begin{array}{l}102 \pm 91 \\
54.9 \\
25.6-246\end{array}$ & $\begin{array}{l}75.6 \pm 36.1 \\
71.6 \\
45.5-135\end{array}$ \\
\hline Dieldrin & $\begin{array}{l}200 \\
(200) \\
126-273\end{array}$ & $\begin{array}{l}356 \pm 57 \\
(363) \\
277-420\end{array}$ & $\begin{array}{l}186 \pm 137 \\
(192) \\
45.9-319\end{array}$ & $\begin{array}{l}102 \pm 49 \\
(108) \\
25.0-180\end{array}$ & $\begin{array}{l}73.7 \pm 65.8 \\
(59.3) \\
10.7-147\end{array}$ \\
\hline Mirex & $\begin{array}{l}22.2 \\
(22.2) \\
22-22.5\end{array}$ & $\begin{array}{l}52.7 \pm 16.2 \\
(55.3) \\
27.6-71.4\end{array}$ & $\begin{array}{l}27.2 \pm 8.4 \\
(27.6) \\
18.6-35.4\end{array}$ & $\begin{array}{l}12.3 \pm 7.37 \\
(10.7) \\
3.98-23.8\end{array}$ & $\begin{array}{l}7.18 \pm 4.48 \\
(7.68) \\
2.21-13.8\end{array}$ \\
\hline
\end{tabular}




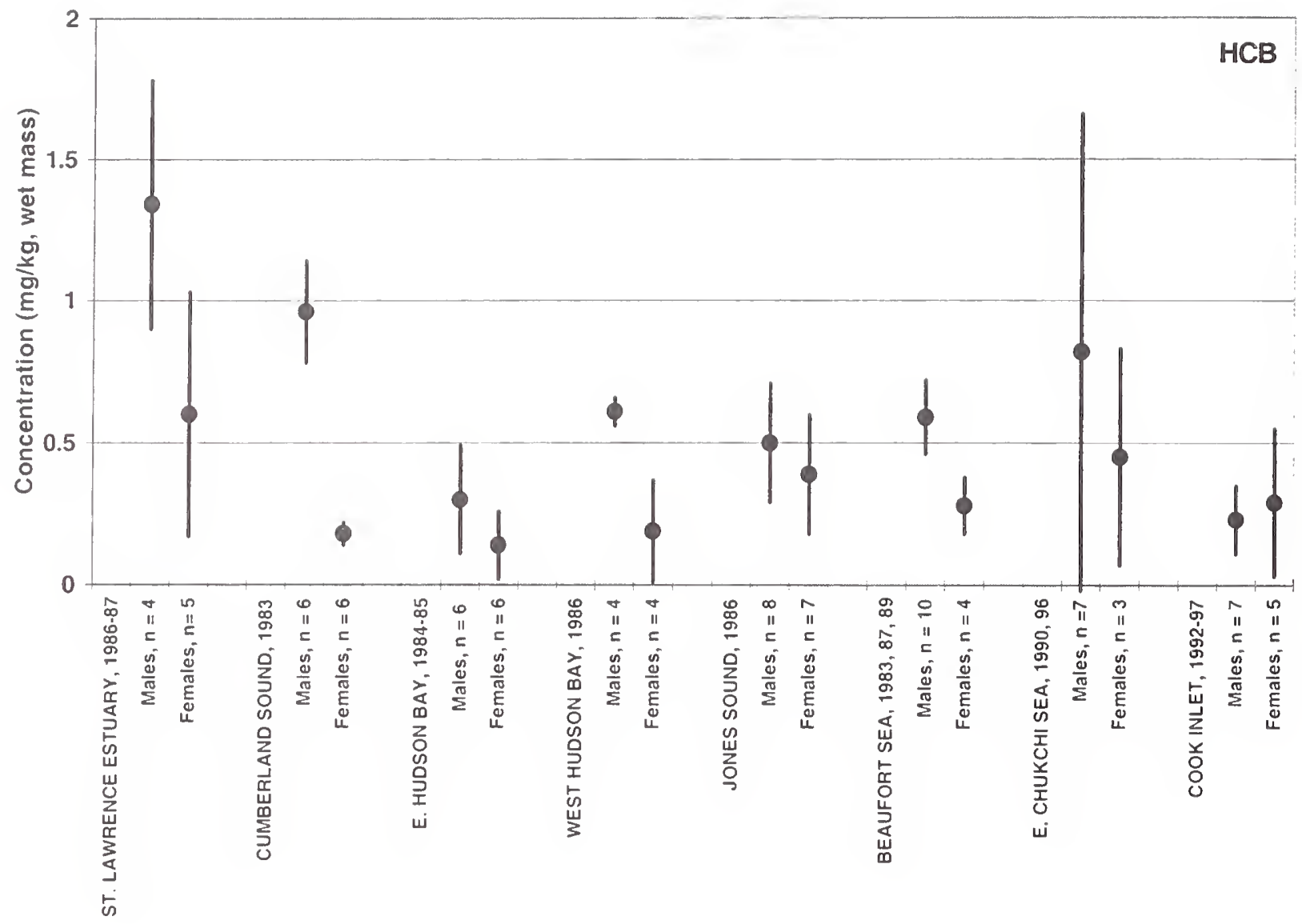

Figure 6. Concentration of $\mathrm{HCB}$ (mean \pm 1 standard deviation) in blubber of Cook Inlet beluga whales compared to concentrations reported in the blubber of other North American populations and stocks of this species. The standard deviation for each mean $(\bullet)$ is indicated by a vertical bar. Geographic locations, dates of sample collections. gender, and number of individuals are shown on the $\underline{X}$ axis. Data are from Becker et al. (1995b), Muir et al. (1990), and NIST (this report). The Beaufort Sea stock is represented by animals sampled from the Mackenzie River Estuary (Muir et al., 1990) and Point Hope, Alaska (Becker et al., 1995b). 


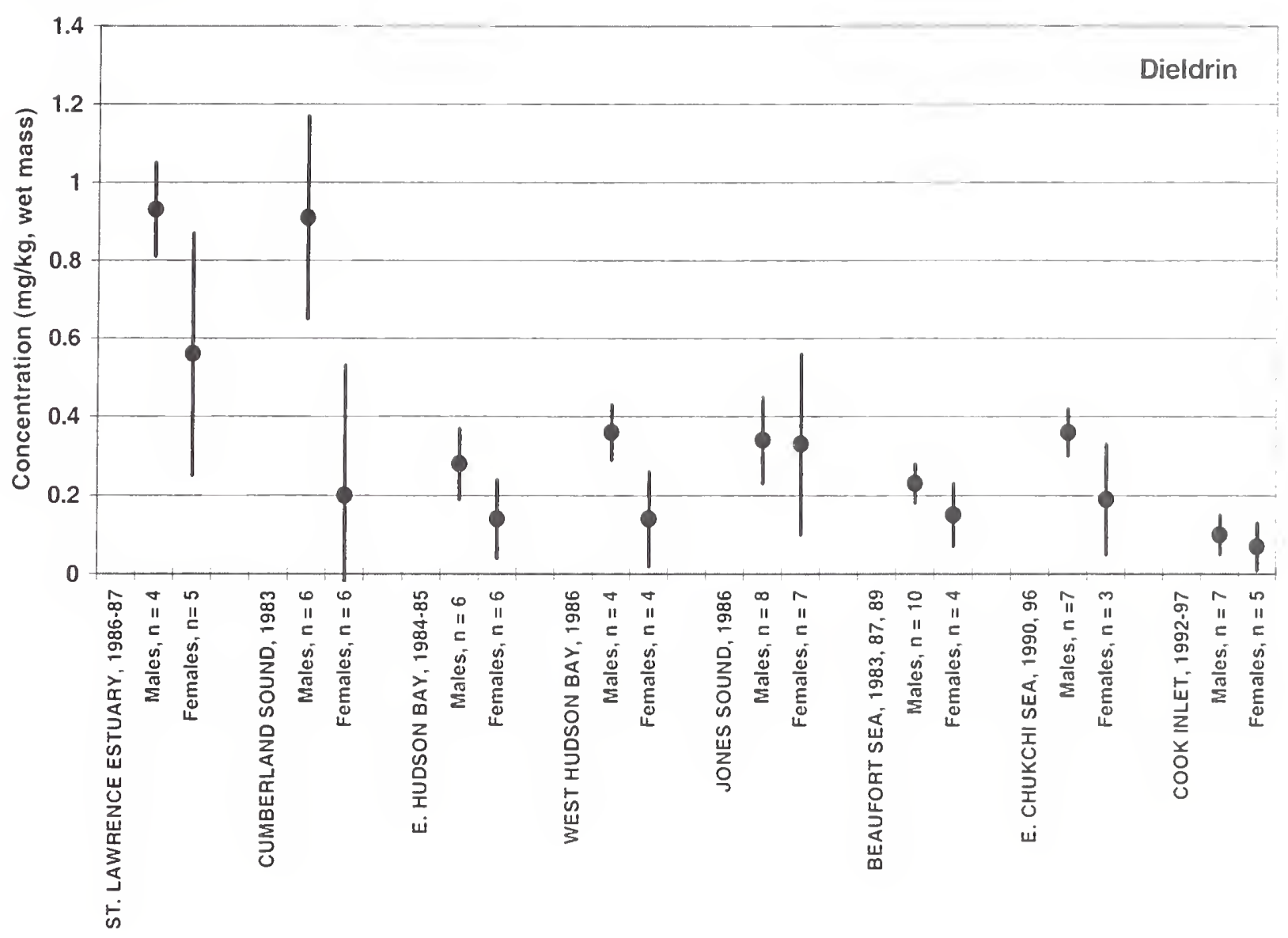

Figure 7. Concentration of dieldrin (mean \pm 1 standard deviation) in blubber of Cook Inlet beluga whales compared to concentrations reported in the blubber of other North American populations and stocks of this species. The standard deviation for each mean $(\bullet)$ is indicated by a vertical bar. Geographic locations, dates of sample collections, gender, and number of individuals are shown on the $\underline{X}$ axis. Data are from Becker et al. (1995b), Muir et al. (1990), and NIST (this report). The Beaufort Sea stock is represented by animals sampled from the Mackenzie River Estuary (Muir et al., 1990) and Point Hope, Alaska (Becker et al., 1995b). 


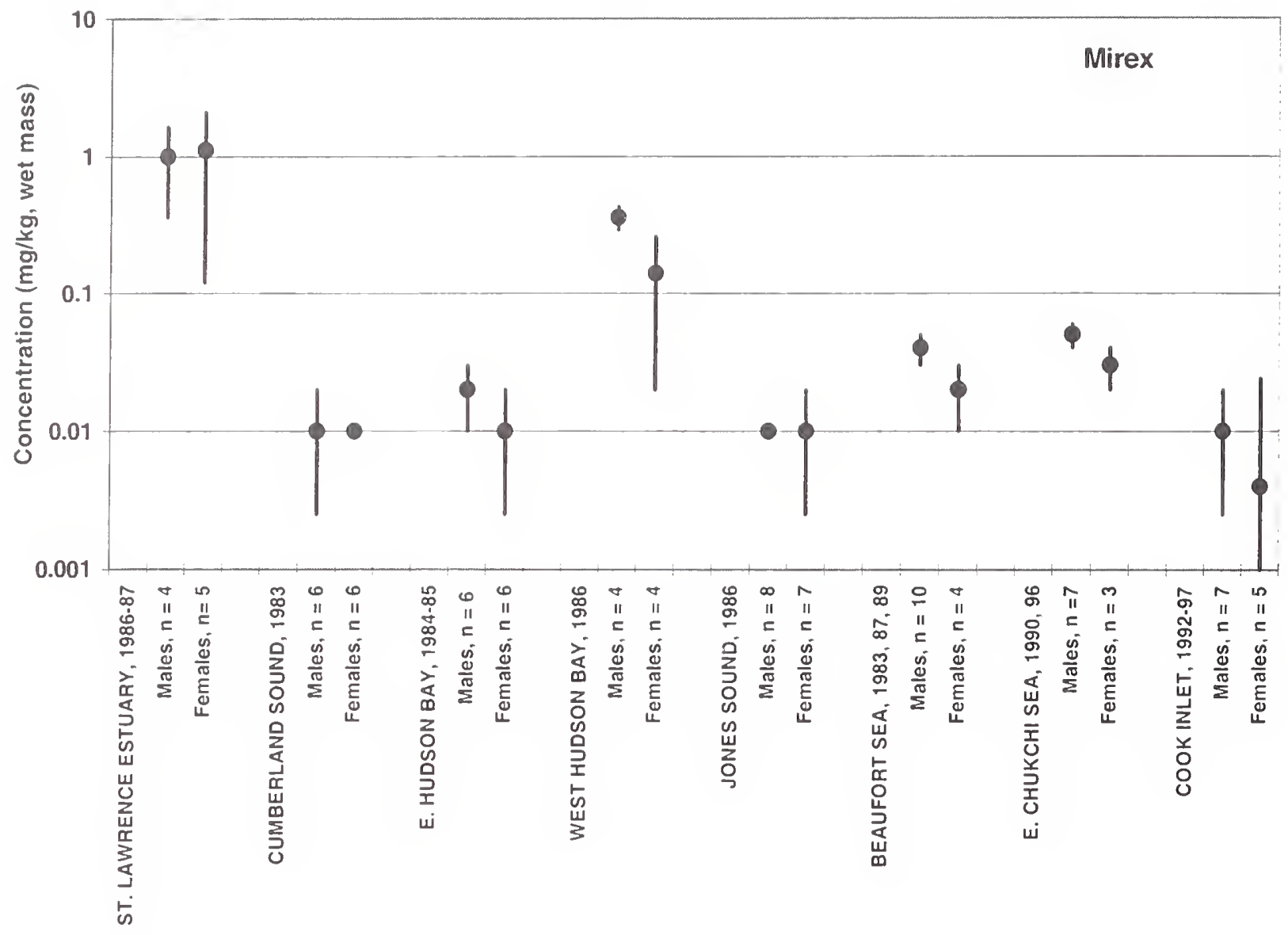

Figure 8. Concentration of mirex (mean \pm 1 standard deviation) in blubber of Cook Inlet beluga whales compared to concentrations reported in the blubber of other North American populations and stocks of this species. The standard deviation for each mean $(\bullet)$ is indicated by a vertical bar. Geographic locations, dates of sample collections, gender, and number of individuals are shown on the $\underline{X}$ axis. Data are from Becker et al. (1995b), Muir et al. (1990), and NIST (this report). The Beaufort Sea stock is represented by animals sampled from the Mackenzie River Estuary (Muir et al., 1990) and Point Hope, Alaska (Becker et al., 1995b). 
In the case of $\mathrm{HCB}$, the difference between the male Cook Inlet animals and those from Point Lay were significant; however, there was little difference between the females of all three stocks. Unlike the other chlorinated compounds, HCB concentrations in the beluga whales throughout the Arctic (Table 6 and Fig. 6) are comparable to concentrations reported in pilot whales and harbor porpoises of the North Atlantic, i.e., $43 \mathrm{ng} / \mathrm{g}$ to $179 \mathrm{ng} / \mathrm{g}$ wet mass for pilot whales and $223 \mathrm{ng} / \mathrm{g}$ to $1070 \mathrm{ng} / \mathrm{g}$ wet mass for harbor porpoise (Becker et al.. 1999). This is consistent with the "Global Fractionation and Polar Condensation" theory of Wania and Mackay, in which the atmospheric transport and global deposition of persistent organic contaminants has been related to the log octanol-air partition coefficient, subcooled liquid vapor pressure, and temperature of condensation of individual compounds. Based on these factors, HCB has relatively high mobility and has been identified as a compound that is preferentially deposited and accumulated in polar latitudes (Wania and Mackay, 1993).

The only $\mathrm{HCH}$ isomer included in this report is $\alpha-\mathrm{HCH}$, which is the isomer that usually dominates the total $\mathrm{HCH}$ concentration in marine mammal blubber. Concentrations of $\beta-\mathrm{HCH}$ and $\gamma-\mathrm{HCH}$ are not reported because the former is lost during the aminopropylsilane cleanup step in the analytical procedure, and $\gamma$ - $\mathrm{HCH}$ was not separated from an unknown interfering peak during the GC-ECD analysis. Although the mean concentration of $\alpha-\mathrm{HCH}$ was higher in the male than in female Cook Inlet beluga whales, the standard deviation for the males was very large (Table 6). This was primarily due to two males that had concentrations of this compound 3 to 10 times higher than any of the other males.

In summary, although occurring in what one might consider a region under substantially more anthropogenic influence than other Alaska belugas, the Cook Inlet animals had lower concentration levels of PCBs and chlorinated pesticides than have been reported for other Alaskan stocks of this species or for this species from other areas of the North America. Krahn et al. (1999) using principal components analysis were able to clearly demonstrate pattern differences in individual analytes between blubber of the Cook Inlet animals and that of the Eastern Chukchi Sea stock. Also, the relative importance of chlordane compounds to the contaminant loads of the Cook Inlet animals is substantially less than for the other North American stocks.

\section{LIVER AND KIDNEY ANALYSES}

For most marine mammal species, little is known about normal concentration ranges of elements in specific tissues. Concentrations of essential elements, such as zinc, copper, and selenium, and potentially toxic elements, such as cadmium and mercury, are commonly measured in liver and kidney. Unlike persistent chlorinated compounds, all elements (including the potentially toxic ones) occur naturally and in many cases elevated tissue levels in animals may reflect natural geochemical and biological food web processes rather than anthropogenic sources.

Data resulting from the analyses of liver and kidney tissues from 10 Cook Inlet Beluga whales (six males. four females, and one female fetus) for 37 elements and methylmercury are presented in the Appendix, Tables C and D, and a summary of the data for 20 of these analytes is presented in Table 7. Generally, the concentrations of zinc in the liver and kidney tissues were similar, with an indication of slightly higher concentrations in the liver. Concentrations of magnesium. vanadium, mercury, selenium, silver, and copper were higher in liver than kidney, while cadmium, calcium, bromine, and chlorine were higher in kidney.

The concentrations of 19 elements and methylmercury measured in the livers of 10 Cook Inlet belugas are presented and compared in Table 8 with data published on belugas sampled by AMMTAP from Point Hope and Point Lay, Alaska (Becker et al., 1995b). In addition, liver concentrations of mercury, selenium, cadmium, copper, and zinc in these animals are compared in Figures 9 through 13 with published data from west Greenland (Dietz et al., 1990; Hansen et al., 1990) and six locations in Canada (Wagemann et al., 1990; 
Table 7. Concentrations of selected elements in livers and kidneys of Cook Inlet beluga whales. Values (mg/kg, wet mass) are given as means \pm 1 standard deviation and ranges. Numbers of individuals are in parentheses.

\begin{tabular}{|c|c|c|c|c|}
\hline & \multicolumn{2}{|c|}{ Males (6) } & \multicolumn{2}{|c|}{ Females (4) } \\
\hline & Livers & Kidneys & Livers & Kidneys \\
\hline $\mathrm{Na}$ & $\begin{array}{l}1331 \pm 191 \\
1101-1567\end{array}$ & $\begin{array}{l}2182 \pm 168 \\
1884-2349\end{array}$ & $\begin{array}{l}1204 \pm 200 \\
1136-1576\end{array}$ & $\begin{array}{l}2181 \pm 157 \\
1950-2296\end{array}$ \\
\hline $\mathrm{Mg}$ & $\begin{array}{l}149.8 \pm 16.9 \\
131-177\end{array}$ & $\begin{array}{l}120 \pm 26 \\
94.4-165\end{array}$ & $\begin{array}{l}134 \pm 26 \\
111-162\end{array}$ & $\begin{array}{l}112 \pm 23 \\
86.4-135\end{array}$ \\
\hline $\mathrm{Cl}$ & $\begin{array}{l}1610 \pm 269 \\
1312-1971\end{array}$ & $\begin{array}{l}2350 \pm 309 \\
1811-2688\end{array}$ & $\begin{array}{l}1312 \pm 198 \\
1251-1561\end{array}$ & $\begin{array}{l}2223 \pm 218 \\
1922-2398\end{array}$ \\
\hline $\mathrm{K}$ & $\begin{array}{l}2898 \pm 310.8 \\
2552-3306\end{array}$ & $\begin{array}{l}1932 \pm 145 \\
1799-2178\end{array}$ & $\begin{array}{l}2849 \pm 322 \\
2516-3021\end{array}$ & $\begin{array}{l}1946 \pm 188 \\
1814-2223\end{array}$ \\
\hline $\mathrm{Ca}$ & $\begin{array}{l}41.6 \pm 6.5 \\
34.7-50.3\end{array}$ & $\begin{array}{l}665 \pm 811 \\
169-2232\end{array}$ & $\begin{array}{l}26.7 \pm 2.9 \\
24.0-30.95\end{array}$ & $\begin{array}{l}228 \pm 188 \\
69.0-331\end{array}$ \\
\hline V & $\begin{array}{l}0.041 \pm 0.012 \\
0.021-0.054\end{array}$ & $\begin{array}{l}0.024 \pm 0.010 \\
0.007-0.035\end{array}$ & $\begin{array}{l}0.034 \pm 0.022 \\
0.015-0.065\end{array}$ & $\begin{array}{l}0.020 \pm 0.003 \\
0.017-0.022\end{array}$ \\
\hline Mn & $\begin{array}{l}2.17 \pm 0.330 \\
1.70-2.52\end{array}$ & $\begin{array}{l}0.760 \pm 0.293 \\
0.441-1.24\end{array}$ & $\begin{array}{l}2.65 \pm 0.72 \\
1.62-3.25\end{array}$ & $\begin{array}{l}0.690 \pm 0.334 \\
0.377-1.01\end{array}$ \\
\hline $\mathrm{Fe}$ & $\begin{array}{l}317 \pm 117 \\
228-494\end{array}$ & $\begin{array}{l}208 \pm 258 \\
64.0-732\end{array}$ & $\begin{array}{l}235 \pm 149 \\
100-443\end{array}$ & $\begin{array}{l}83.0 \pm 28.8 \\
57.5-124\end{array}$ \\
\hline $\mathrm{Co}$ & $\begin{array}{l}0.009 \pm 0.002 \\
0.006-0.012\end{array}$ & $\begin{array}{l}0.014 \pm 0.002 \\
0.013-0.017\end{array}$ & $\begin{array}{l}0.028 \pm 0.041 \\
0.005-0.090\end{array}$ & $\begin{array}{l}0.013 \pm 0.005 \\
0.006-0.018\end{array}$ \\
\hline $\mathrm{Cu}$ & $\begin{array}{l}48.9 \pm 39.8 \\
15.6-124\end{array}$ & $\begin{array}{l}3.44 \pm 1.60 \\
1.92-6.15\end{array}$ & $\begin{array}{l}29.3 \pm 20.1 \\
3.97-48.3\end{array}$ & $\begin{array}{l}4.56 \pm 1.27 \\
2.70-5.55\end{array}$ \\
\hline $\mathrm{Zn}$ & $\begin{array}{l}27.26 \pm 2.265 \\
24.56-30.64\end{array}$ & $\begin{array}{l}25.8 \pm 2.81 \\
23.0-30.4\end{array}$ & $\begin{array}{l}24.4 \pm 1.59 \\
22.7-26.1\end{array}$ & $\begin{array}{l}21.0 \pm 2.20 \\
18.8-23.0\end{array}$ \\
\hline As & $\begin{array}{l}0.078 \pm 0.023 \\
<0.05-0.120\end{array}$ & $<0.070-<0.100$ & $\begin{array}{r}0.356 \pm 0.329 \\
<0.070-0.815\end{array}$ & $\begin{array}{c}0.183 \pm 0.036 \\
<0.060-0.2005\end{array}$ \\
\hline $\mathrm{Se}$ & $\begin{array}{l}4.35 \pm 1.56 \\
2.91-6.09\end{array}$ & $\begin{array}{l}2.29 \pm 1.05 \\
1.20-3.87\end{array}$ & $\begin{array}{l}2.62 \pm 1.55 \\
1.08-4.22\end{array}$ & $\begin{array}{l}1.93 \pm 1.13 \\
0.410-3.14\end{array}$ \\
\hline $\mathrm{Br}$ & $\begin{array}{l}17.83 \pm 4.26 \\
13.17-22.48\end{array}$ & $\begin{array}{l}22.1 \pm 5.0 \\
15.0-28.6\end{array}$ & $\begin{array}{l}17.3 \pm 7.3 \\
10.2-25.0\end{array}$ & $\begin{array}{l}21.0 \pm 8.2 \\
13.0-29.0\end{array}$ \\
\hline $\mathrm{Rb}$ & $\begin{array}{l}1.76 \pm 0.267 \\
1.37-2.08\end{array}$ & $\begin{array}{l}1.46 \pm 0.35 \\
0.775-1.78\end{array}$ & $\begin{array}{l}1.39 \pm 0.17 \\
1.22-1.60\end{array}$ & $\begin{array}{l}0.905 \pm 0.183 \\
0.687-1.09\end{array}$ \\
\hline
\end{tabular}


Table 7, continued. Concentrations of selected elements in livers and kidneys of Cook Inlet beluga whales. Values ( $\mathrm{mg} / \mathrm{kg}$, wet mass) are given as means \pm 1 standard deviation and ranges. Numbers of individuals are in parentheses.

\begin{tabular}{|c|c|c|c|c|}
\hline & \multicolumn{2}{|c|}{ Males (6) } & \multicolumn{2}{|c|}{ Females (4) } \\
\hline & Livers & Kidneys & Livers & Kidneys \\
\hline $\mathrm{Ag}$ & $\begin{array}{l}6.78 \pm 4.17 \\
1.51-11.6\end{array}$ & $\begin{array}{c}12.2 \pm 12.2 \\
<0.005-36.7\end{array}$ & $\begin{array}{l}4.38 \pm 4.46 \\
0.637-9.79\end{array}$ & $\begin{array}{r}0.031 \pm 0.020 \\
<0.003-0.045\end{array}$ \\
\hline $\mathrm{Cd}$ & $\begin{array}{l}<1 \\
<0.44-<1\end{array}$ & $\begin{array}{l}4.51 \pm 2.32 \\
2.49-8.98\end{array}$ & $\begin{array}{l}0.63 \pm 0.155 \\
<0.5-0.74\end{array}$ & $\begin{array}{c}3.00 \pm 1.13 \\
<0.370-4.20\end{array}$ \\
\hline Cs & $\begin{array}{l}0.051 \pm 0.024 \\
0.009-0.075\end{array}$ & $\begin{array}{l}0.067 \pm 0.025 \\
0.045-0.115\end{array}$ & $\begin{array}{l}0.064 \pm 0.009 \\
0.056-0.075\end{array}$ & $\begin{array}{l}0.055 \pm 0.005 \\
0.049-0.061\end{array}$ \\
\hline $\mathrm{Hg}$ & $\begin{array}{l}5.45 \pm 3.47^{3} \\
2.98-11.4^{3}\end{array}$ & $\begin{array}{l}3.65 \pm 1.71^{2} \\
2.44-4.86^{2}\end{array}$ & $\begin{array}{l}2.57 \pm 1.82 \\
0.704-5.03\end{array}$ & $\mathrm{nd}^{3}$ \\
\hline Methyl Hg & $\begin{array}{l}1.47 \pm 0.66^{3} \\
0.800-2.11^{3}\end{array}$ & $\begin{array}{l}1.80 \pm 0.431 \\
1.50-2.11\end{array}$ & $\begin{array}{l}0.52 \pm 0.25 \\
0.34-0.70\end{array}$ & nd \\
\hline
\end{tabular}

$\mathrm{n}=3$

${ }^{2} \mathrm{n}=2$.

${ }^{3}$ nd - not determined 
Table 8. Concentrations of selected elements in livers of Alaska beluga whales. Values ( $\mathrm{mg} / \mathrm{kg}$, wet mass) are given as means \pm 1 standard deviation and ranges. Numbers of individuals are in parentheses.

\begin{tabular}{|c|c|c|c|c|c|c|}
\hline & \multicolumn{2}{|c|}{$\begin{array}{l}\text { Beaufort Sea (1989) } \\
\text { Point Hope, Alaska }\end{array}$} & \multicolumn{2}{|c|}{$\begin{array}{l}\text { Eastern Chukchi Sea } \\
\text { Point Lay, Alaska }\end{array}$} & \multicolumn{2}{|c|}{$\begin{array}{c}\text { Cook Inlet } \\
\text { Cook Inlet, Alaska }\end{array}$} \\
\hline & Males (1) & Females (3) & Males (7) & Females (3) & Males (6) & Female (4) \\
\hline $\mathrm{Na}$ & 960.5 & $\begin{array}{l}1198 \pm 145.6 \\
1049-1340\end{array}$ & $\begin{array}{l}1397 \pm 150.8 \\
1136-1576\end{array}$ & $\begin{array}{l}1321 \pm 176.8 \\
1141-1494\end{array}$ & $\begin{array}{l}1331 \pm 191 \\
1101-1567\end{array}$ & $\begin{array}{l}1204 \pm 200 \\
983-1449\end{array}$ \\
\hline $\mathrm{Mg}$ & 111.8 & $\begin{array}{l}151.4 \pm 70.4 \\
78.5-219\end{array}$ & $\begin{array}{l}116.9 \pm 33.18 \\
58.5-164\end{array}$ & $\begin{array}{l}157.6 \pm 16.10 \\
140.5-172.5\end{array}$ & $\begin{array}{l}149.8 \pm 16.9 \\
131.2-177.4\end{array}$ & $\begin{array}{l}134.5 \pm 26 \\
111-162.2\end{array}$ \\
\hline $\mathrm{Cl}$ & 1384 & $\begin{array}{l}1481 \pm 83.0 \\
1392-1556\end{array}$ & $\begin{array}{l}1814 \pm 87.98 \\
1638-1880\end{array}$ & $\begin{array}{l}1684 \pm 171.6 \\
1486-1790\end{array}$ & $\begin{array}{l}1610 \pm 269 \\
1312-1971\end{array}$ & $\begin{array}{l}1312 \pm 198 \\
1251-1561\end{array}$ \\
\hline $\mathrm{K}$ & 2272 & $\begin{array}{l}2524 \pm 196.2 \\
2315-2704\end{array}$ & $\begin{array}{l}2222 \pm 486.9 \\
1523-2700\end{array}$ & $\begin{array}{l}1754 \pm 601.9 \\
1326-2442\end{array}$ & $\begin{array}{l}2898 \pm 310.8 \\
2552-3306\end{array}$ & $\begin{array}{l}2849 \pm 322 \\
2516-3021\end{array}$ \\
\hline $\mathrm{Ca}$ & 30.82 & $\begin{array}{l}26.3 \pm 0.878 \\
25.30-26.92\end{array}$ & $\begin{array}{l}31.64 \pm 10.55 \\
20.5-44\end{array}$ & $\begin{array}{l}32.7 \pm 7.145 \\
28.5-40.95\end{array}$ & $\begin{array}{l}41.6 \pm 6.46 \\
34.7-50.3\end{array}$ & $\begin{array}{l}26.7 \pm 2.91 \\
24-30.95\end{array}$ \\
\hline V & 0.034 & $\begin{array}{l}0.079 \pm 0.026 \\
0.049-0.095\end{array}$ & $\begin{array}{l}0.1644 \pm 0.063 \\
0.037-0.205\end{array}$ & $\begin{array}{l}0.1529 \pm 0.1092 \\
0.0898-0.279\end{array}$ & $\begin{array}{l}0.041 \pm 0.012 \\
0.021-0.054\end{array}$ & $\begin{array}{l}0.034 \pm 0.022 \\
0.015-0.065\end{array}$ \\
\hline Mn & 2.506 & $\begin{array}{l}3.211 \pm 0.134 \\
3.093-3.357\end{array}$ & $\begin{array}{l}1.939 \pm 0.313 \\
1.62-2.4\end{array}$ & $\begin{array}{l}1.918 \pm 0.2812 \\
1.656-2.215\end{array}$ & $\begin{array}{l}2.17 \pm 0.33 \\
1.70-2.52\end{array}$ & $\begin{array}{l}2.651 \pm 0.72 \\
1.617-3.254\end{array}$ \\
\hline $\mathrm{Fe}$ & 587.5 & $\begin{array}{l}457.3 \pm 143.6 \\
362.5-622.5\end{array}$ & $\begin{array}{l}599 \pm 92.95 \\
474.5-726\end{array}$ & $\begin{array}{l}558.2 \pm 224.3 \\
332-780.5\end{array}$ & $\begin{array}{l}316.9 \pm 116.7 \\
228.0-494.5\end{array}$ & $\begin{array}{l}235.0 \pm 149.0 \\
100.0-443.0\end{array}$ \\
\hline Co & 0.011 & $\begin{array}{l}0.1 \pm 0.06 \\
0.01-0.18\end{array}$ & $\begin{array}{l}0.012 \pm 0.002 \\
0.008-0.015\end{array}$ & $\begin{array}{l}0.015 \pm 0.006 \\
0.008-0.021\end{array}$ & $\begin{array}{l}0.009 \pm 0.002 \\
0.006-0.012\end{array}$ & $\begin{array}{l}0.0281 \pm 0.041 \\
0.005-0.0895\end{array}$ \\
\hline $\mathrm{Cu}$ & 12.36 & $\begin{array}{l}12.86 \pm 1.336 \\
12-14.40\end{array}$ & $\begin{array}{l}12.66 \pm 6.45 \\
6.85-26.4\end{array}$ & $\begin{array}{l}21.18 \pm 17.43 \\
7.1-40.68\end{array}$ & $\begin{array}{l}48.93 \pm 39.79 \\
15.62-123.8\end{array}$ & $\begin{array}{l}29.26 \pm 20.09 \\
3.97-48.27\end{array}$ \\
\hline $\mathrm{Zn}$ & 22.62 & $\begin{array}{l}33.67 \pm 4.324 \\
30.24-38.53\end{array}$ & $\begin{array}{l}23.86 \pm 2.76 \\
21.1-28.65\end{array}$ & $\begin{array}{l}23.68 \pm 2.62 \\
20.90-26.1\end{array}$ & $\begin{array}{l}27.26 \pm 2.265 \\
24.56-30.64\end{array}$ & $\begin{array}{l}24.38 \pm 1.591 \\
22.66-26.07\end{array}$ \\
\hline As & 0.177 & $\begin{array}{l}0.215 \pm 0.046 \\
0.163-0.252\end{array}$ & $\begin{array}{l}0.160 \pm 0.203 \\
0.065-0.616\end{array}$ & $\begin{array}{l}0.180 \pm 0.020 \\
0.162-0.201\end{array}$ & $\begin{array}{l}0.078 \pm 0.023 \\
<0.05-0.120\end{array}$ & $\begin{array}{l}0.356 \pm 0.329 \\
<0.07-0.815\end{array}$ \\
\hline $\mathrm{Se}$ & 6.243 & $\begin{array}{l}8.472 \pm 5.261 \\
3.961-14.25\end{array}$ & $\begin{array}{l}18.55 \pm 8.77 \\
7.01-29.36\end{array}$ & $\begin{array}{l}37.33 \pm 33.07 \\
18.20-75.51\end{array}$ & $\begin{array}{l}4.347 \pm 1.561 \\
2.907-6.088\end{array}$ & $\begin{array}{l}2.620 \pm 1.547 \\
1.078-4.215\end{array}$ \\
\hline $\mathrm{Br}$ & 25.62 & $24.36(n=1)$ & $\begin{array}{l}20.45 \pm 1.70 \\
18.36-23.06\end{array}$ & $\begin{array}{l}25.31 \pm 9.373 \\
17.22-35.58\end{array}$ & $\begin{array}{l}17.83 \pm 4.26 \\
13.17-22.48\end{array}$ & $\begin{array}{l}17.28 \pm 7.321 \\
10.22-25.00\end{array}$ \\
\hline $\mathrm{Rb}$ & & $\begin{array}{l}1.346(n=2) \\
1.174-1.518\end{array}$ & $\begin{array}{l}1.050 \pm 0.463 \\
0.09-1.493\end{array}$ & $1.717(n=1)$ & $\begin{array}{l}1.765 \pm 0.267 \\
1.372-2.084\end{array}$ & $\begin{array}{l}1.387 \pm 0.174 \\
1.222-1.602\end{array}$ \\
\hline
\end{tabular}


Table 8, continued. Concentrations of selected elements in livers of Alaska beluga whales. Values ( $\mathrm{mg} / \mathrm{kg}$, wet mass) are given as means \pm 1 standard deviation and ranges. Numbers of individuals are in parentheses.

\begin{tabular}{|c|c|c|c|c|c|c|}
\hline & $\begin{array}{l}\text { Beaufor } \\
\text { Point } \mathrm{H}\end{array}$ & $\begin{array}{l}\text { (1989) } \\
\text { Alaska }\end{array}$ & $\begin{array}{c}\text { Eastern Chu } \\
\text { Point Lay, }\end{array}$ & $\begin{array}{l}\text { kchi Sea } \\
\text { Alaska }\end{array}$ & $\begin{array}{r}\text { Cor } \\
\text { Cook In }\end{array}$ & $\begin{array}{l}\text { Inlet } \\
\text { t, Alaska }\end{array}$ \\
\hline & Males (1) & Females (3) & Males (7) & Females (3) & Males (6) & Female (4) \\
\hline $\mathrm{Ag}$ & 14.58 & $\begin{array}{l}20.83 \pm 8.538 \\
14.36-30.51\end{array}$ & $\begin{array}{l}24.32 \pm 10.65 \\
14.38-40.69\end{array}$ & $\begin{array}{l}46.62 \pm 52.98 \\
10.05-107.4\end{array}$ & $\begin{array}{l}6.778 \pm 4.169 \\
1.513-11.61\end{array}$ & $\begin{array}{l}4.383 \pm 4.463 \\
0.637-9.787\end{array}$ \\
\hline $\mathrm{Cd}$ & 0.75 & $\begin{array}{l}1.307 \pm 0.745 \\
0.455-1.840\end{array}$ & $\begin{array}{l}1.884 \pm 0.438 \\
1.14-2.41\end{array}$ & $\begin{array}{l}3.333 \pm 0.501 \\
2.755-3.645\end{array}$ & $\begin{array}{l}<1 \\
<0.44-<1\end{array}$ & $\begin{array}{l}0.63 \pm 0.155 \\
<0.5-0.74\end{array}$ \\
\hline Cs & 0.021 & $\begin{array}{l}0.038 \pm 0.007 \\
0.031-0.038\end{array}$ & $\begin{array}{l}0.028 \pm 0.003 \\
0.024-0.033\end{array}$ & $\begin{array}{l}0.033 \pm 0.003 \\
0.030-0.035\end{array}$ & $\begin{array}{l}0.051 \pm 0.024 \\
0.009-0.075\end{array}$ & $\begin{array}{l}0.0644 \pm 0.0094 \\
0.0556-0.0746\end{array}$ \\
\hline $\mathrm{Hg}$ & 3.52 & $\begin{array}{l}5.462 \pm 4.428 \\
1.397-10.18\end{array}$ & $\begin{array}{l}36.53 \pm 16.81 \\
17.73-50.14\end{array}$ & $\begin{array}{l}52.64 \pm 22.86 \\
27.85-72.9\end{array}$ & $\begin{array}{l}5.454 \pm 3.471 \\
2.98-11.42\end{array}$ & $\begin{array}{l}2.568 \pm 1.816 \\
0.704-5.03\end{array}$ \\
\hline Methyl $\mathrm{H}$ & $\lg 0.49$ & $\begin{array}{l}0.513 \pm 0.231 \\
0.37-0.78\end{array}$ & $\begin{array}{l}1.517 \pm 0.592 \\
0.86-2.01\end{array}$ & $\begin{array}{l}1.153 \pm 0.395 \\
0.85-1.6\end{array}$ & $\begin{array}{l}1.47 \pm 0.66 \\
0.800-2.11\end{array}$ & $\begin{array}{l}0.52 \pm 0.25 \\
0.34-0.70\end{array}$ \\
\hline
\end{tabular}

${ }^{1} \mathrm{n}=3$ 


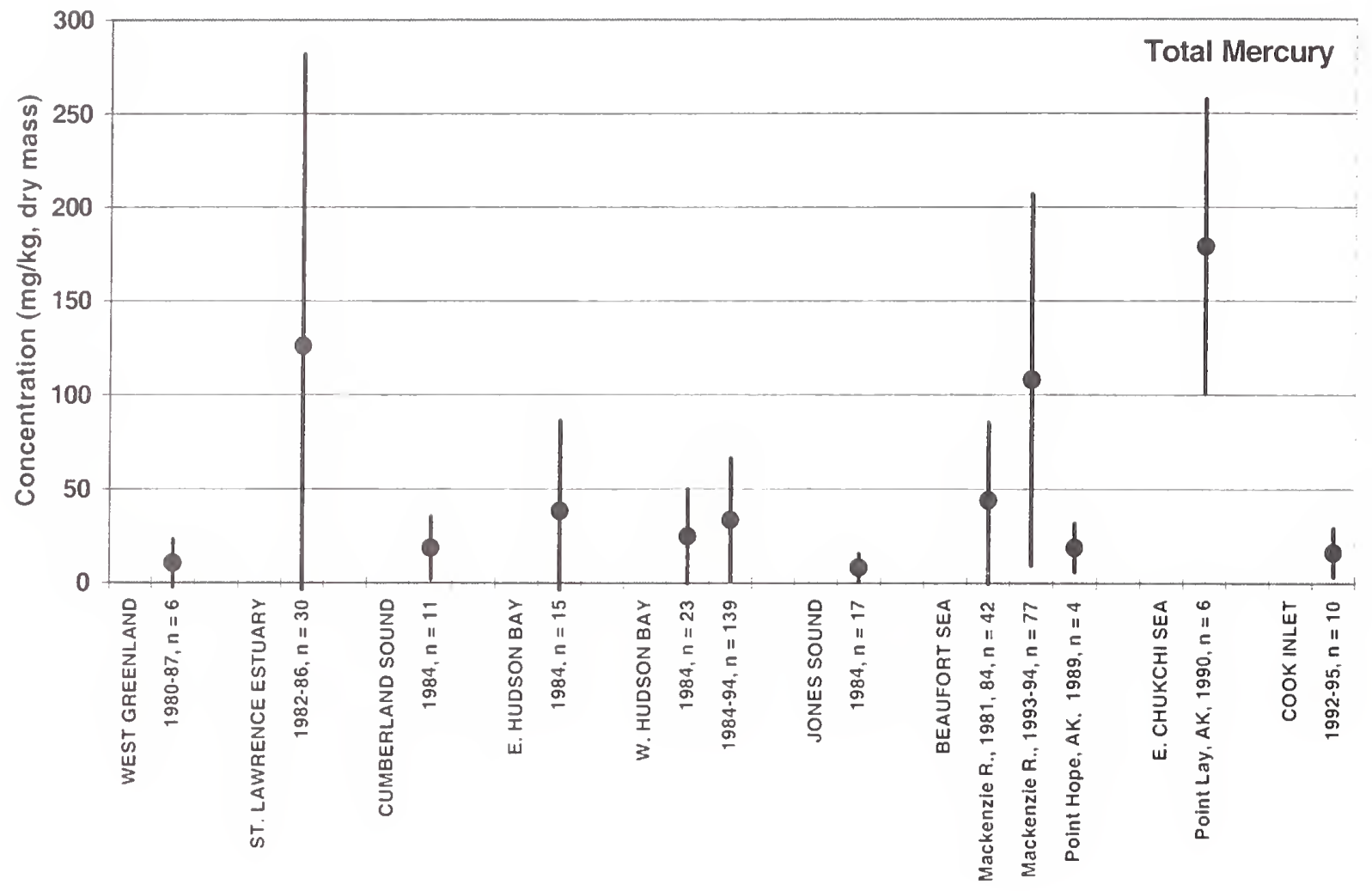

Figure 9. Concentration of total mercury (mean \pm 1 standard deviation) in liver tissue of Cook Inlet beluga whales compared to concentrations reported in livers of other North American populations and stocks of this species. The standard deviation for each mean $(\bullet)$ is indicated by a vertical bar. Geographic locations, dates of sample collections, and numbers of animals are shown on the $\underline{X}$ axis. Animals from the Mackenzie River and Point Hope are thought to be from the Beaufort Sea Stock. Data are from Dietz et al. (1990), Wagemann et al. (1990; 1996), Becker et al. (1995b), and NIST (this report). 


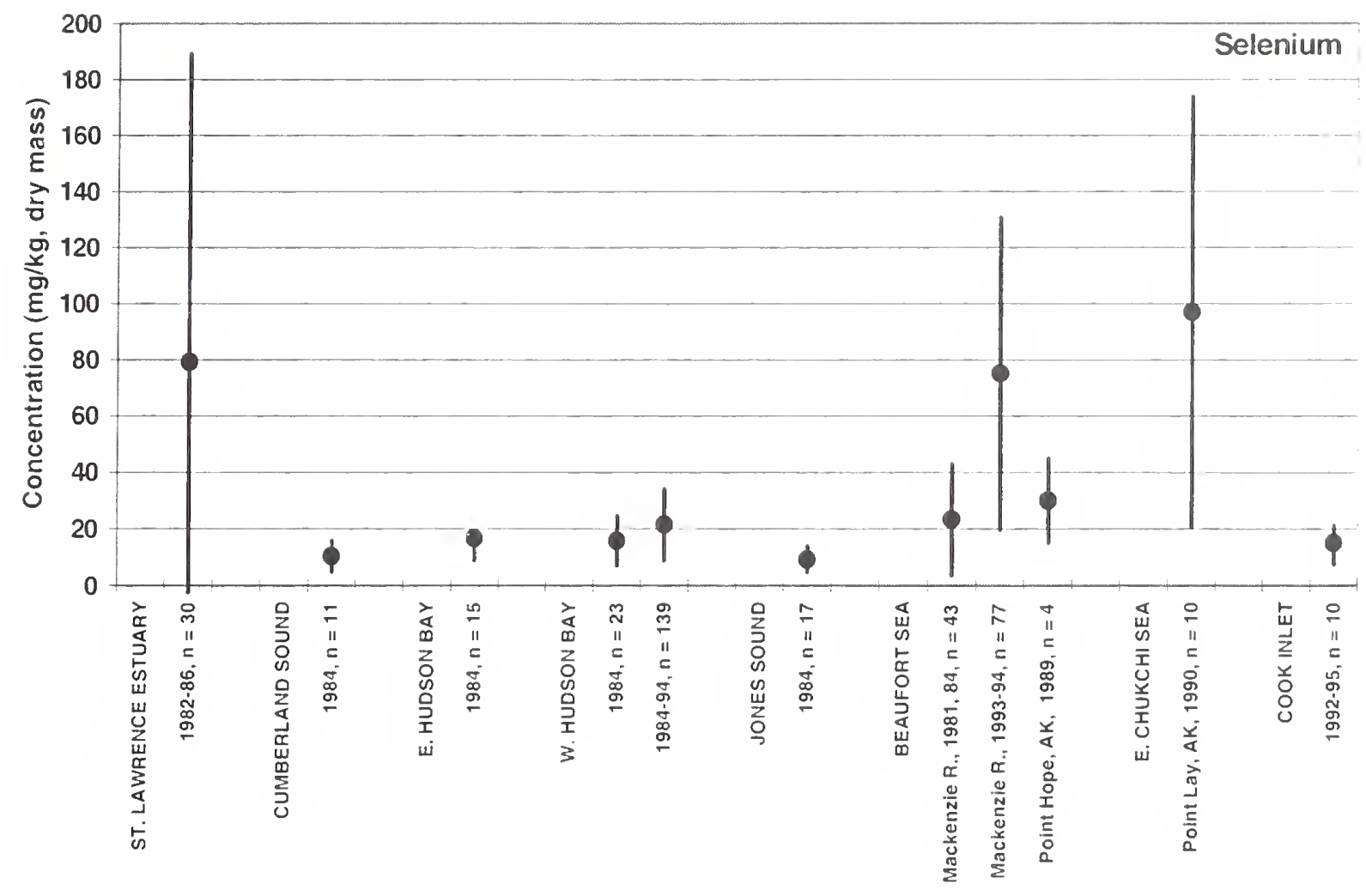

Figure 10. Concentration of selenium (mean \pm 1 standard deviation) in liver tissue of Cook Inlet beluga whales compared to concentrations reported in livers of other North American populations and stocks of this species. The standard deviation for each mean $(\bullet)$ is indicated by a vertical bar. Geographic locations, dates of sample collections, and numbers of animals are shown on the $\underline{X}$ axis. Animals from the Mackenzie River and Point Hope are thought to be from the Beaufort Sea Stock. Data are from Wagemann et al. $(1990 ; 1996)$, Becker et al. (1995b), and NIST (this report). 


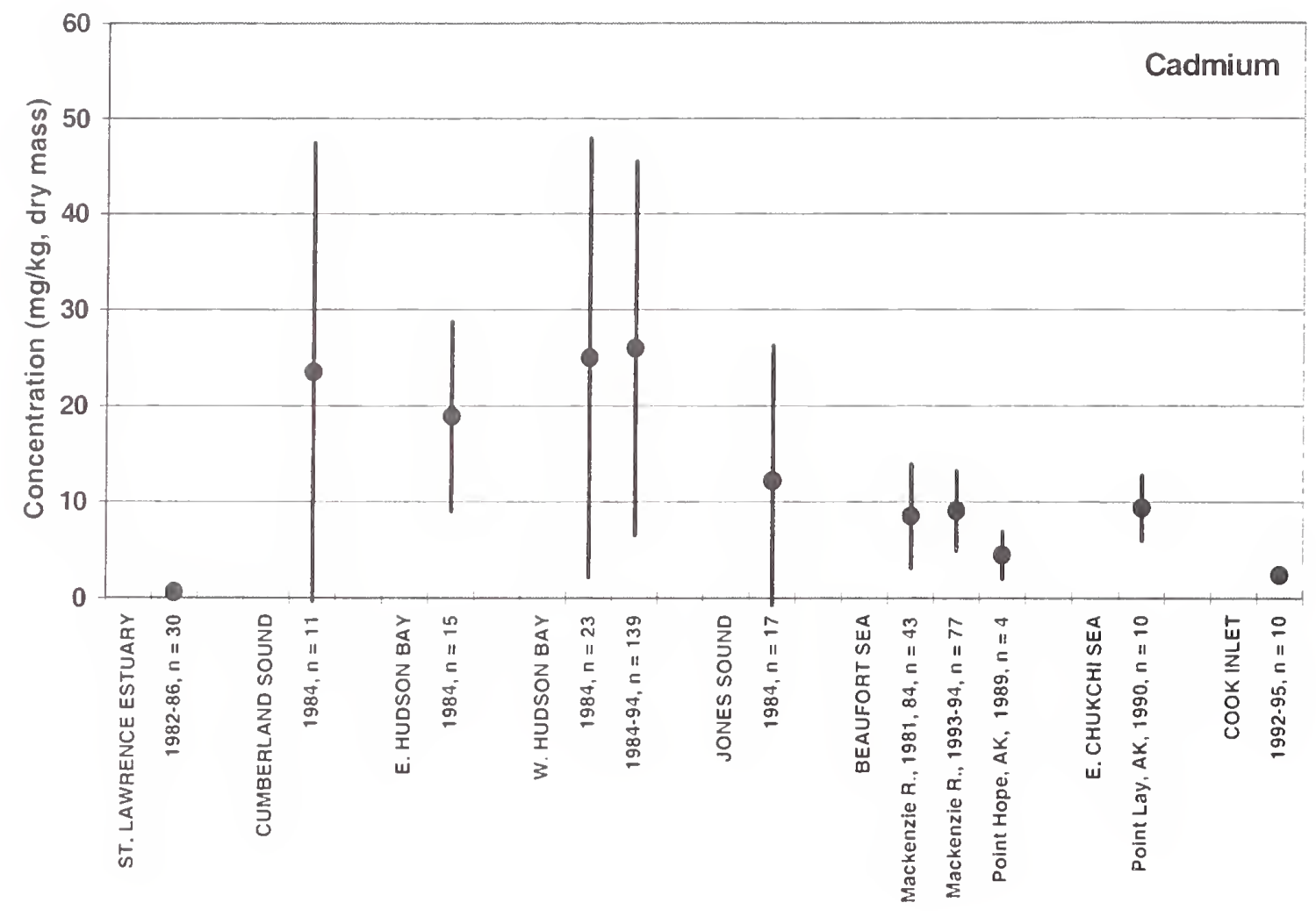

Figure 11. Concentration of cadmium (mean \pm 1 standard deviation) in liver tissue of Cook Inlet beluga whales compared to concentrations reported in livers of other North American populations and stocks of this species. The standard deviation for each mean $(\bullet)$ is indicated by a vertical bar. Geographic locations, dates of sample collections, and numbers of animals are shown on the $\underline{X}$ axis. Animals from the Mackenzie River and Point Hope are thought to be from the Beaufort Sea Stock. Data are from Wagemann et al. (1990; 1996), Becker et al. (1995b), and NIST (this report). 


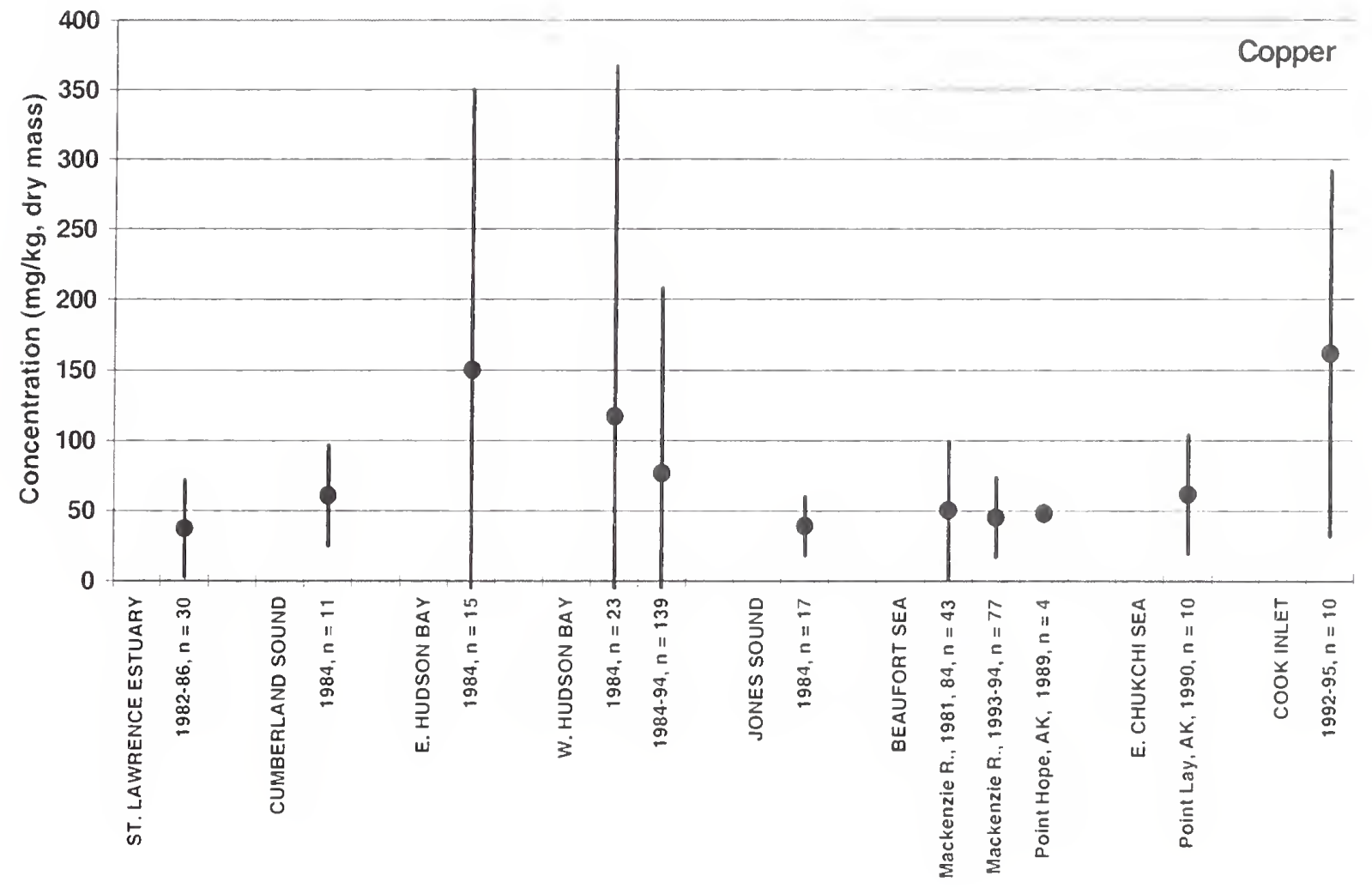

Figure 12. Concentration of copper (mean \pm 1 standard deviation) in liver tissue of Cook Inlet beluga whales compared to concentrations reported in livers of other North American populations and stocks of this species. The standard deviation for each mean $(\bullet)$ is indicated by a vertical bar. Geographic locations, dates of sample collections, and numbers of animals are shown on the $\underline{X}$ axis. Animals from the Mackenzie River and Point Hope are thought to be from the Beaufort Sea Stock. Data are from Wagemann et al. (1990; 1996), Becker et al. (1995b), and NIST (this report). 


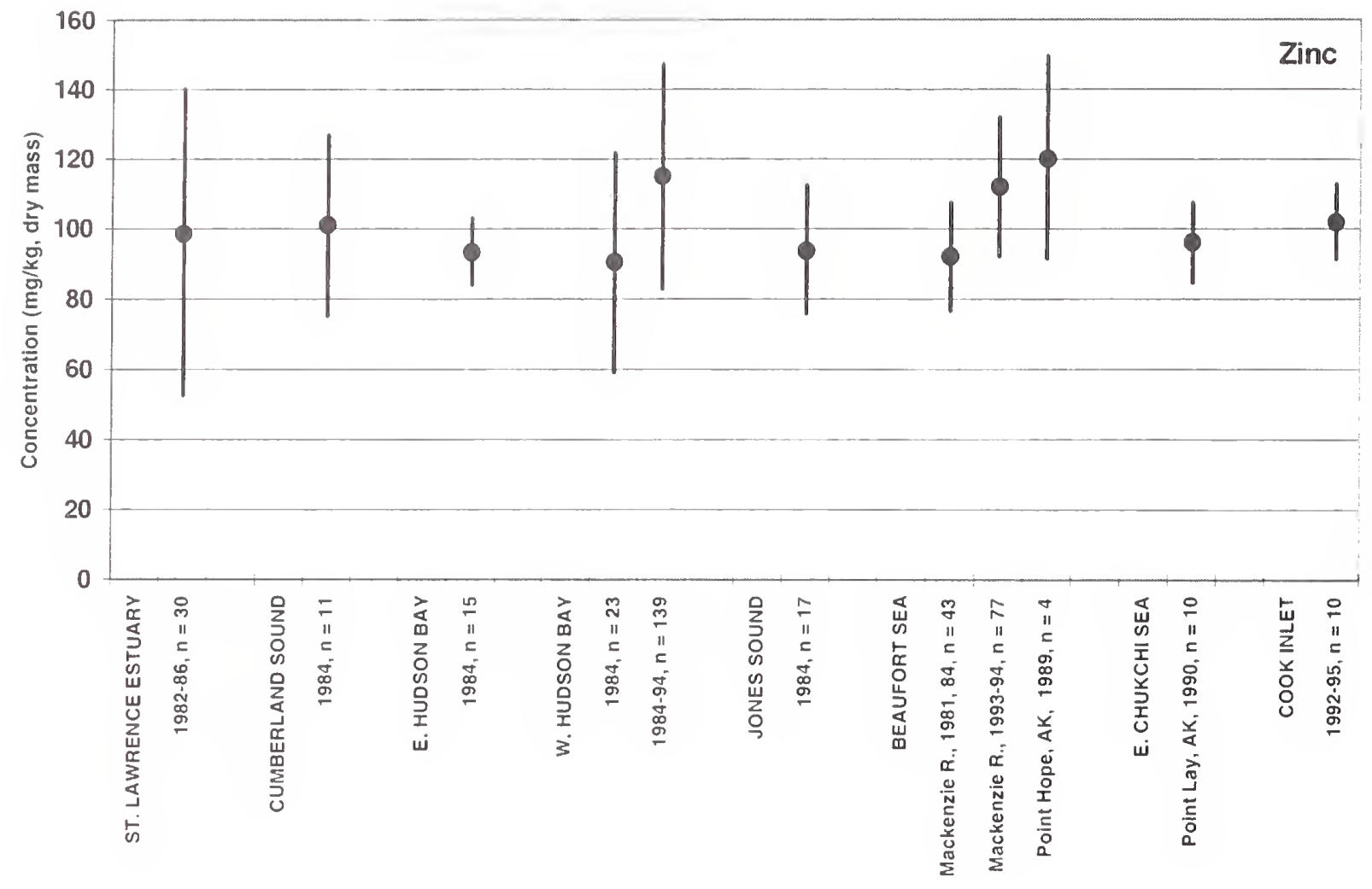

Figure 13. Concentration of zinc (mean \pm 1 standard deviation) in liver tissue of Cook Inlet beluga whales compared to concentrations reported in livers of other North American populations and stocks of this species. The standard deviation for each mean $(\bullet)$ is indicated by a vertical bar. Geographic locations, dates of sample collections, and numbers of animals are shown on the $\underline{X}$ axis. Animals from the Mackenzie River and Point Hope are thought to be from the Beaufort Sea Stock. Data are from Wagemann et al. (1990; 1996), Becker et al. (1995b), and NIST (this report). 
1996). The values reported from Canada (the largest database) are based on dry mass concentrations. Therefore, for direct comparison with these published values, the wet mass concentrations of these five elements in the Alaska animals were converted to dry mass values using percent moisture data for each individual sample. The conversion factors of wet mass to dry mass for the Cook Inlet and Point Hope animals were $0.26 \pm 0.02$ (mean \pm 1 standard deviation) and $0.25 \pm 0.01$ for the Point Lay animals. The data from west Greenland was converted from wet mass to dry mass basis using the conversion factor of 0.25 . Since the west Greenland and Canadian papers do not differentiate concentrations in males and females, the data presented in Figures 9 to 13 represent both genders.

As in the case of the persistent organic contaminants, these regional comparisons use data generated over a decade. Recent studies by Wagemann et al. (1996) indicate that. at least for the eastern Canadian Arctic. there has been little change in the concentrations of cadmium in beluga livers from 1981 to 1994; however, hepatic mercury concentrations were significantly higher in both the eastern Canadian animals and the western (Beaufort Sea) from 1993 to 1994, than from 1981 to 1984. Wagemann et al. (1996) also suggest there is a higher rate of mercury accumulation recently than was the case 15 years ago.

\section{Mercury, Methylmercury, Selenium, and Silver}

Mercury is present at relatively high concentrations in the livers of beluga whales throughout North America. These levels are quite similar to those reported for Atlantic pilot whales, Globicephalus melas (Becker et al., 1995b; Mackey et al.. 1995; Meador et al., 1993). Among the Alaskan animals, the mean concentration of mercury in livers of the Cook Inlet animals was an order of magnitude lower than that reported recently for the Beaufort Sea (Wagemann et al., 1996) and Eastern Chukchi Sea stocks (significant at the 99\% confidence level) (Table 8 and Fig. 9). Compared with most other beluga whales in North America, hepatic mercury levels in the Cook Inlet animals were at the low end of the range of values and similar to those reported for animals from Greenland and Cumberland Sound, Canada.

The mercury values shown in Figure 9 are for total mercury, which includes both inorganic and organic forms of this element. The toxic form of this element is methylmercury, which for animals with high total mercury concentrations in livers, usually contributes a relatively small fraction to the total concentration in this organ (Fig. 14a). Although the hepatic total mercury levels were lowest in the Cook Inlet animals, methylmercury concentrations were similar among all three Alaskan stocks. Concentrations in the animals from Cook Inlet ranged from $0.09 \mathrm{mg} / \mathrm{kg}$ wet mass in a fetus to $2.11 \mathrm{mg} / \mathrm{kg}$ wet mass in a large male (median levels were $0.5 \mathrm{mg} / \mathrm{kg}$ wet mass for females and $1.5 \mathrm{mg} / \mathrm{kg}$ wet mass for males. Dietz et al. (1990) in their study of beluga whales and narwhals, Monodon monoceros, from western Greenland, found that for total mercury hepatic concentrations of $<1 \mathrm{mg} / \mathrm{kg}$ wet mass, about half of the mercury was organic and that it did not exceed $2.2 \mathrm{mg} / \mathrm{kg}$ wet mass even with hepatic total mercury concentrations 50 times greater. The hepatic concentration in the fetus and the large male from Cook Inlet $(0.09 \mathrm{mg} / \mathrm{kg}$ to $2.11 \mathrm{mg} / \mathrm{kg}$ wet mass $)$ represents the largest range of methylmercury values found to date in Alaskan beluga whales.

Marine mammals are exposed to methylmercury through their prey (particularly fish). There is some evidence to support the idea that marine mammals are able to metabolically convert the methylmercury consumed to the relatively non-toxic inorganic mercury that is then stored in the liver. If that is the case, over time the inorganic fraction of the hepatic mercury would be expected to increase, but the methylmercury fraction would not. Methylmercury values for all three Alaskan beluga whale stocks generally do not exceed $2 \mathrm{mg} / \mathrm{kg}$ wet mass at the highest levels of total mercury (i.e., up to $73 \mathrm{mg} / \mathrm{kg}$ of total mercury) and the highest percentage of methylmercury occurs at the low end of the total mercury range. The relationship of percent methylmercury with total hepatic mercury shown in Figure 14b for all of the Alaskan beluga whales supports this hypothesis and suggests that a threshold concentration level may exist, above which methylmercury no longer accumulates in this organ. 
(a)

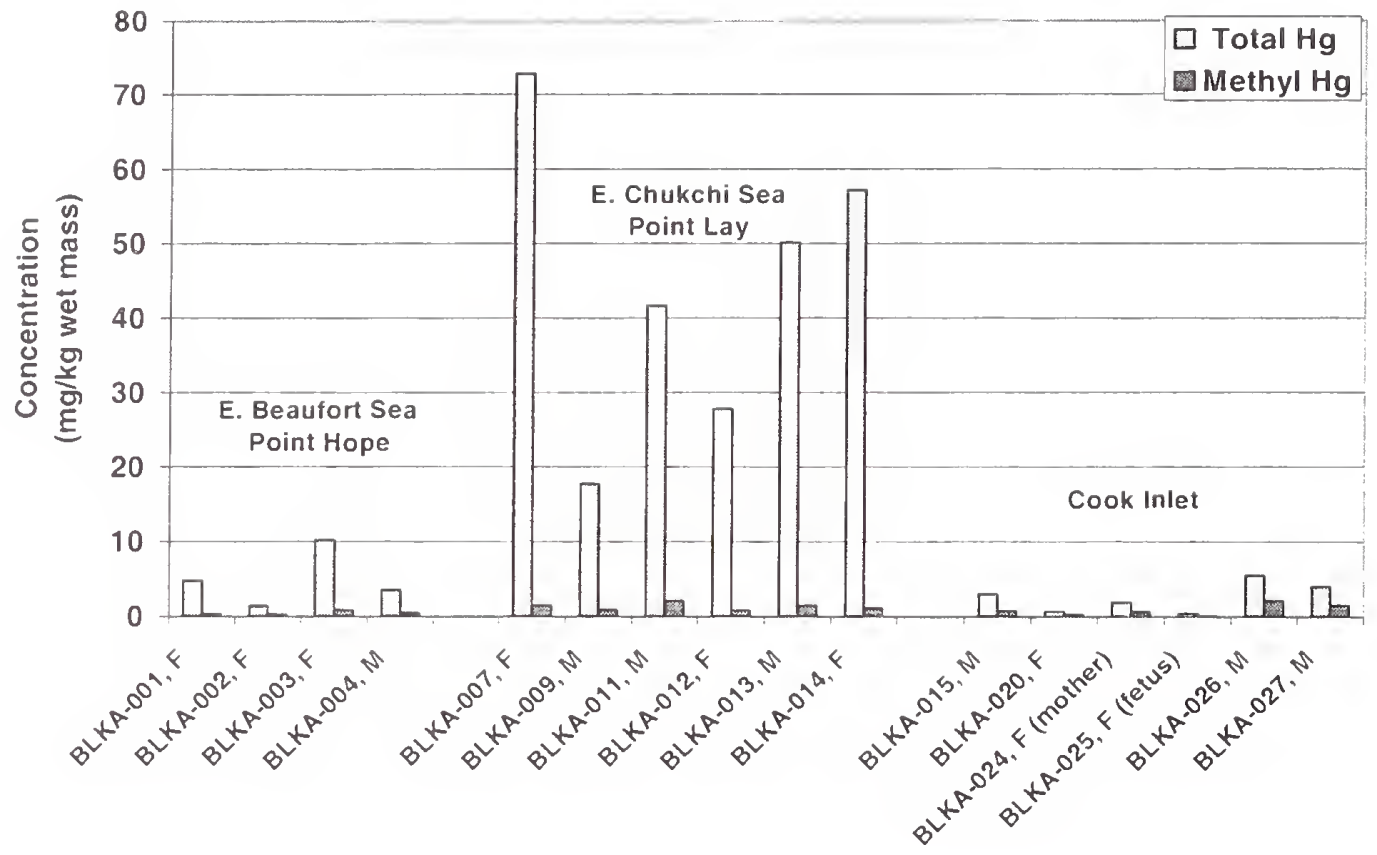

(b)

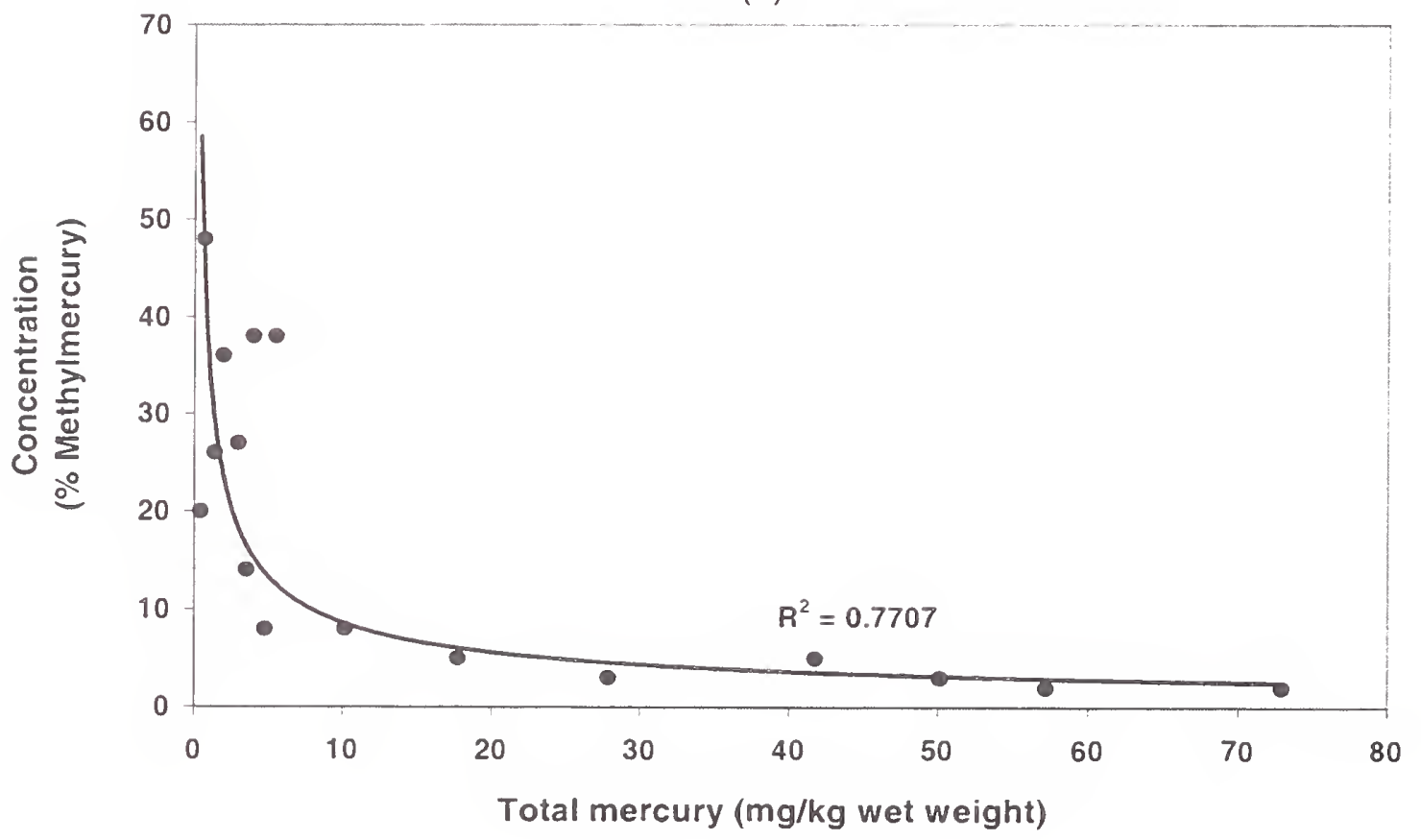

Figure 14. Mercury in liver tissue of beluga whales. (a) Concentration of total mercury and methylmercury in liver tissue of Cook Inlet beluga whales compared to the Point Hope and Point Lay animals. (b) Relationship between methylmercury and total mercury for beluga liver tissue from all three locations. The data are from Becker et al. (1995b) and NIST (this report) 
The positive correlation of concentrations of selenium with mercury in liver tissue has been commonly reported for many species of animals (e.g., Julshamn et al., 1987; Koemann et al., 1973; Mackey et al., 1995; Meador et al., 1993; Muir et al., 1988; Wagemann et al., 1983). In vertebrates, this correlation has been shown for kidney as well as liver. This selenium-mercury relationship is thought to be indicative of both an accumulative and a protective function for the organism by incorporating the mercury within an innocuous complex involving selenium compounds and metal-binding proteins (Hammond and Beliles, 1980). Selenium was positively correlated with mercury concentrations in liver and kidney tissue of the Cook Inlet beluga whales as well as the livers of the Beaufort Sea and Eastern Chukchi Sea stocks. Regression plots of hepatic mercury concentrations versus hepatic selenium concentrations for beluga whales from all three Alaskan stocks yield a linear correlation coefficient $\left(R^{2}\right)$ value of 0.73 (for $n=18$ ).

Silver is not routinely measured in vertebrate tissues. Becker et al. (1995a) reported silver concentrations in the livers of Beaufort Sea and Eastern Chukchi Sea stocks that are one to three orders of magnitude higher than what have been reported for other marine mammal species. The silver concentrations were positively correlated with mercury concentrations, selenium concentrations, and with ages of the animals. A linear relationship between hepatic silver and selenium concentrations also has been observed for several other marine mammal species, although hepatic concentrations of silver in other species are much lower (Mackey et al., 1996). When the silver and selenium concentrations for the Cook Inlet animals are added to the Alaskan beluga whale database, this relationship remains; in fact, the correlation between silver and selenium is much stronger than for mercury and selenium. Regression plots of hepatic silver concentrations versus hepatic selenium concentrations for beluga whales from all three Alaskan stocks yield a linear correlation coefficient $\left(\mathrm{R}^{2}\right)$ value of 0.93 (for $\mathrm{n}=21$ ).

Physiochemical processes that may be involved in the accumulation and possible interaction of selenium, mercury, and silver in beluga whale livers have been described elsewhere (Becker et al., 1995a; Mackey et al., 1996). All three elements were positively correlated with age of the animals, suggesting that independent mechanisms might be involved. However. when adding those few Cook Inlet animals for which age data were available to the database, there was no strong correlation of the concentrations of these three elements with age.

Including the silver data for the Cook Inlet animals in the comparison of beluga whales with other marine mammal species supports the pattern of high levels of this element in the liver tissue of beluga whales (Fig. 15). Although the concentrations in the Cook Inlet animals $(1.52 \mathrm{mg} / \mathrm{kg}$ to $11.61 \mathrm{mg} / \mathrm{kg}$ wet mass) were significantly less than those reported previously for the other two Alaskan stocks $(10.05 \mathrm{mg} / \mathrm{kg}$ to 107.4 $\mathrm{mg} / \mathrm{kg}$ wet mass), the Cook Inlet beluga whales still had much higher levels than those reported for other marine mammal species $(0.01 \mathrm{mg} / \mathrm{kg}$ to $1.50 \mathrm{mg} / \mathrm{kg}$ wet mass) (Becker et al., 1997a). These results suggest that the high level of silver in livers of beluga whales is a species-specific phenomenon and not a geographic phenomenon; however, data from other stocks, including those from eastern Canada and Greenland are necessary to determine if this is true.

\section{Cadmium and Copper}

Cadmium concentrations in the kidneys are usually three to four times higher than in the liver of marine mammals. Hammond and Beliles (1980) state that in humans at low doses, kidney concentrations are about ten times higher than liver concentrations and that with increasing levels of exposure the concentration ratio approaches one. Among Alaskan marine mammals, high concentrations of cadmium in livers and kidneys have been reported for both bowhead whale, Balaena mysticetus, (Krone et al., 1999) and walrus, Odobenus rosmarus (Taylor et al., 1989; Warburton and Seagars, 1993), and probably reflect both biomagnification through the food web and accumulation with increasing age of the animals. As compared to many other marine mammal species, cadmium concentrations are usually relatively low in beluga whales. In fact, the 


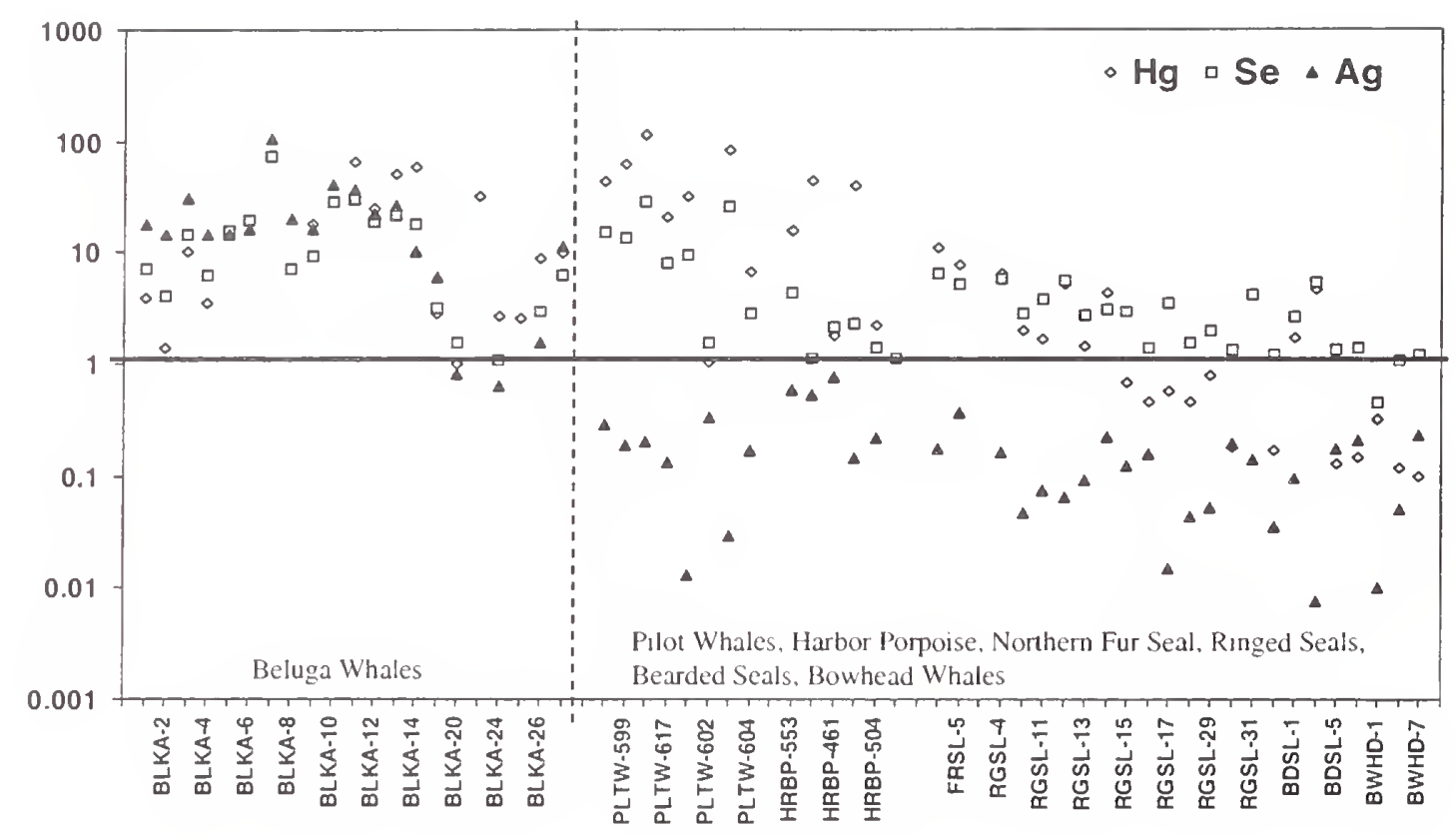

Figure 15. Mercury, selenium, and silver concentrations in livers of beluga whales compared to values for other marine mammal species with liver tissue banked in the NMMTB. 
lowest levels reported for beluga whales were those found in the St. Lawrence Estuary animals, which are considered to be highly contaminated with anthropogenic pollutants (Fig. 11). The concentrations of cadmium in the livers of the Alaskan beluga stocks are relatively low as compared with those reported for beluga whales from Hudson Bay and Cumberland Sound in Canada, but similar to those reported for stocks from Greenland and Jones Sound, Canada (Fig. 11). The lowest hepatic cadmium concentrations were found in the animals from Cook Inlet, where concentrations ranged from the detection limit of $<0.44 \mathrm{mg} / \mathrm{kg}$ to 0.74 $\mathrm{mg} / \mathrm{kg}$ wet mass. Kidney concentrations ranged from $2.16 \mathrm{mg} / \mathrm{kg}$ to $8.99 \mathrm{mg} / \mathrm{kg}$ wet mass (mean \pm 1 standard deviation $=3.98 \pm 2.08 \mathrm{mg} / \mathrm{kg}$ wet mass).

Copper was present in higher concentrations in the livers of Cook Inlet animals than in the other two Alaskan stocks (Table 3). When compared to the Beaufort Sea and Eastern Chukchi Sea stocks, concentrations were on average 2 to 3 times higher in the Cook Inlet animals (significant at the $95 \%$ confidence level). The relatively high average concentration and the high variability of the hepatic copper in the Cook Inlet beluga whales were similar to what has been reported for beluga whales from Hudson Bay (Fig. 12). Copper apparently does not accumulate with age and, in fact, the highest copper concentrations are usually found in the younger animals. Wagemann et al. (1983) reported that copper concentration was negatively correlated with length for narwhals and Honda et al. (1983) found the same relationship for striped dolphin, Stenella coeruleoalba.

\section{Arsenic}

The concentration of arsenic varies a mong tissue types and among species. According to Thompson (1990), concentrations of arsenic in livers of birds and mammals rarely exceed $1 \mathrm{mg} / \mathrm{kg}$ wet mass. However, marine organisms generally contain higher amounts of arsenic (in primarily organic form) than terrestrial or freshwater organisms. It appears that organic forms of arsenic in marine food webs are derived from in vivo synthesis by primary producers and are efficiently transferred along the marine food chain (Wrench et al.. 1979; Maher, 1985). Therefore, marine mammals have the potential for commonly having higher tissue concentrations of arsenic than terrestrial mammals.

Although arsenic concentrations may be higher in benthic than in pelagic animals, the total arsenic concentration in a particular animal is not correlated with its trophic position (Goessler et al., 1998), nor with size or age (Francesconi and Edmonds, 1993). Values of total arsenic reported for marine animals include $3.5 \mathrm{mg} / \mathrm{kg}$ to $26 \mathrm{mg} / \mathrm{kg}$ wet mass in crustacean muscles and up to $166 \mathrm{mg} / \mathrm{kg}$ in fish muscle (Francesconi and Edmonds, 1993). Most of this arsenic is in the form of arsenobetaine, a non-toxic compound.

Tissues with high lipid content generally have the highest concentrations of arsenic (i.e., liver, fat, and muscle). Concentrations in livers were generally higher than those of kidneys in both male and female Cook Inlet beluga whales (Table 7). Concentrations in livers ranged from $<0.05 \mathrm{mg} / \mathrm{kg}$ to $0.815 \mathrm{mg} / \mathrm{kg}$ wet mass and in kidneys from $<0.07 \mathrm{mg} / \mathrm{kg}$ to $0.20 \mathrm{mg} / \mathrm{kg}$ wet mass. These values are within the range of arsenic concentrations that have been reported for other cetaceans (Becker et al., 1997a), including the Beaufort Sea and Eastern Chukchi Sea beluga whale stocks (Table 8).

A large portion of the total arsenic in the liver tissue of Cook Inlet beluga whales is probably in organic form. Bratton et al. (1993) reported $98 \%$ of the total arsenic in the livers of a bowhead whale (Balaena mysticetus) to be arsenobetaine. Although none of the Cook Inlet specimens have been analyzed for organic arsenic compounds, Goessler et al. (1998) extracted and identified six arsenic compounds found to be above the detection limit $(0.001 \mathrm{mg} / \mathrm{kg})$ in the liver tissues of four marine mammal species, i.e., pilot whale (Globicephala melas), ringed seal (Phoca hispida), bearded seal (Erignathus barbatus), and beluga whale. Beluga whale was represented by one animal from Point Lay. Arsenobetaine dominated the concentrations of arsenic compounds ( $68 \%$ to $98 \%$ of the extractable arsenic). Other compounds quantified were 
arsenocholine $(0.5 \%$ to $9 \%)$, tetramethylarsonium cation ( $1 \%$ to $10 \%$; not found in pilot whale or beluga whale), dimethylarsinic acid ( $0.4 \%$ to $9 \%$, except for the beluga whale which was $22 \%)$, methylarsonic acid, and an unknown arsenic compound. Although tetramethylarsonium cation represented $1 \%$ to $10 \%$ of the extractable arsenic in the pinnipeds, it was not found in livers of either pilot or beluga whales. Dimethylarsinic acid contributed $0.4 \%$ to $9 \%$ of the extractable arsenic in the marine mammals; however, in the beluga whale, it contributed much more to the total organic portion ( $22 \%$ of the extractable).

\section{Vanadium}

Vanadium in marine mammals has been of interest to NIST, since Mackey et al. (1996) reported higher concentrations of vanadium in livers banked from Alaska marine mammals as compared to those from marine mammals of the United States east coast. In the latter case, vanadium concentrations were at or below detection limits $(<0.01 \mathrm{mg} / \mathrm{kg})$, while in the livers of Alaska marine mammals, concentrations ranged from $0.02 \mathrm{mg} / \mathrm{kg}$ to $3.8 \mathrm{mg} / \mathrm{kg}$ wet mass. The highest liver levels were reported by Warburton and Seagars (1993) for walrus (0.25 to $3.8 \mathrm{mg} / \mathrm{kg}$ wet mass), while the lowest levels were reported by Mackey et al. (1996) for beluga whales (0.3 to $1.9 \mathrm{mg} / \mathrm{kg}$ wet mass) from the Beaufort Sea, Eastern Chukchi Sea, and one animal from the Cook Inlet stocks.

There is some evidence indicating that vanadium may be essential for normal reproductive physiology and bone growth of mammals (Nielsen and Ulthus, 1990). Although this element is physiologically regulated by mammals, long-term exposure to vanadium in the environment results in accumulation in bone, kidney, liver, and muscle (Stoecker and Hopkins, 1984). At elevated levels this element may interfere with bone development and depress growth rates (Wide, 1984; Hill, 1990).

Vanadium concentrations in livers were slightly higher than in the kidneys of the Cook Inlet beluga whales (Table 7). Among the Alaska beluga whales, hepatic concentrations were lowest in the Cook Inlet animals (Table 8). Cook Inlet beluga whales had the lowest hepatic concentrations of all of the Alaska marine mammal species $(0.021$ to $0.065 \mathrm{mg} / \mathrm{kg}$ wet mass), but still substantially higher than what has been reported for marine mammals from the lower latitudes of the United States (Fig. 16). The presence of relatively high levels of vanadium in the livers of the Alaska animals may reflect a unique dietary source of vanadium, a unique geochemical source, or anthropogenic input to the Alaskan marine environment. These factors have been discussed extensively by Mackey et al. (1996).

\section{Calcium and Zinc}

Average calcium concentrations were an order of magnitude higher in the kidneys than in the livers of the Cook Inlet beluga whales (Table 7). Mean liver concentrations were $41.6 \pm 6.46 \mathrm{mg} / \mathrm{kg}$ and $26.7 \pm 2.91$ $\mathrm{mg} / \mathrm{kg}$ wet mass for males and females, respectively. These values are similar to those for the Beaufort Sea and Eastern Chukchi Sea stocks (Table 8) and are similar to concentrations of this element reported for livers from pilot whales, harbor porpoises (Phocoena phocoena), white-sided dolphins (Lagenorhynchus acutus), and bowhead whales (Becker et al., 1997a).

Concentrations of essential trace elements, such as calcium and zinc, are generally characterized by relatively narrow range of values within a species and with ranges similar from one species to another. These elements are essential for normal health of animals and are well regulated metabolically. Liver and kidney concentrations of the Cook Inlet beluga whales were almost identical (Table 7). Hepatic zinc concentrations among the Alaskan beluga whales vary from $11 \%$ to $25 \%$ of the average values (Table 8 ) and are quite similar to hepatic values reported for other cetaceans (Becker et al., 1997a). A comparison of the Alaska beluga whale data with data published by Wagemann et al. $(1990 ; 1996)$ shows that the range of hepatic zinc concentrations is very consistent for beluga whales throughout the Arctic and eastern Canada (Fig. 13). 


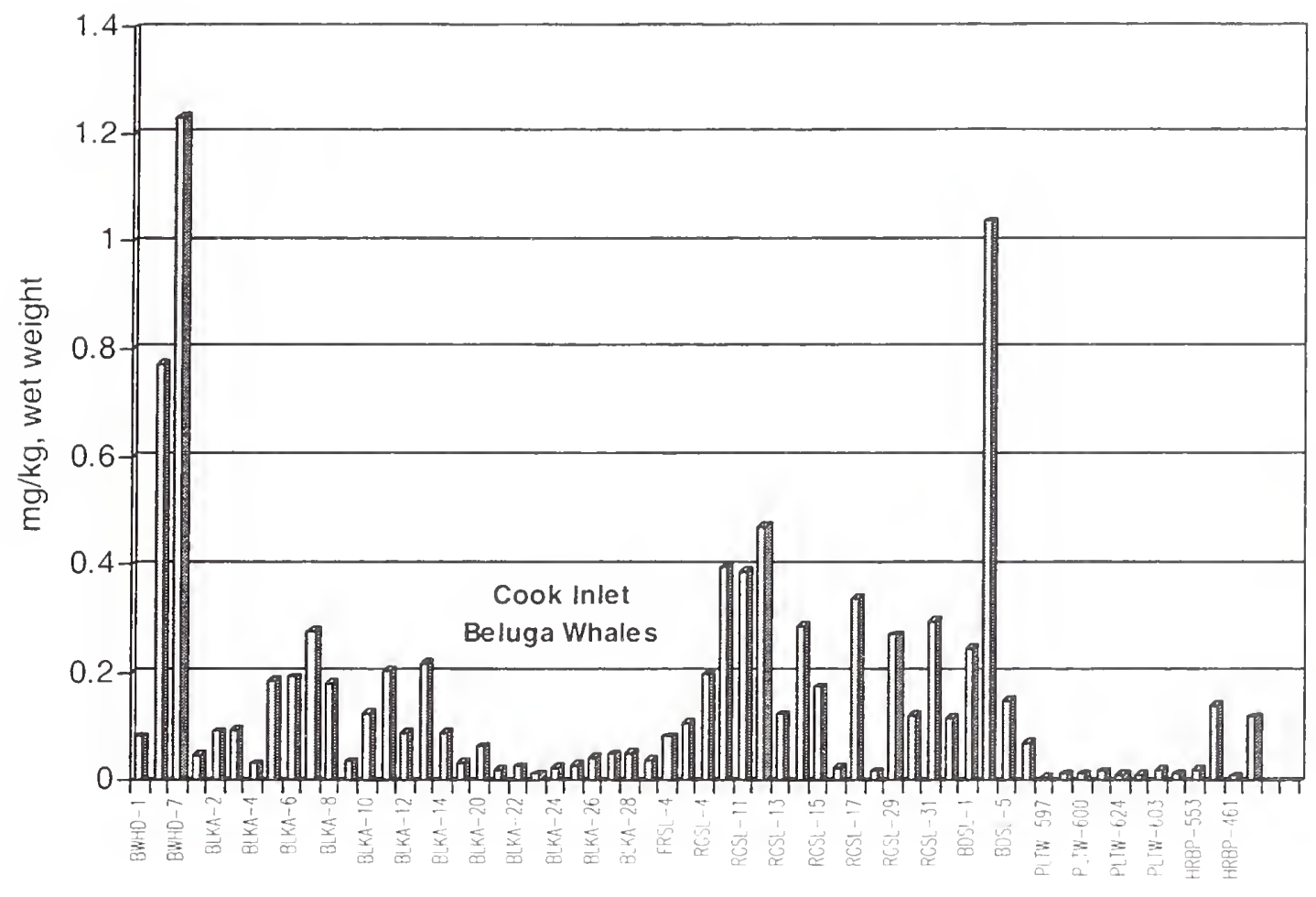

Figure 16. Concentration of vanadium in marine mammal livers. Values are in $\mathrm{mg} / \mathrm{kg}$, wet mass. Data are from Becker et al. (1995b) and NIST (this report). BWHD - bowhead whale, BLKA - beluga whale, FRSL - northern fur seal, RGSL - ringed seal, BDSL- bearded seal, PLTW - pilot whale. HRBP - harbor porpoise. 
In summary, in addition to having relatively low concentrations of persistent chlorinated compounds in their blubber, the Cook Inlet beluga whales also had relatively low levels of mercury, selenium, silver, vanadium, and cadmium in their livers (relative to other beluga stocks). Mackey et al. (1996) reported a positive correlation of liver concentrations of all five of these elements with increasing age in beluga whales. However, only a few of the Cook Inlet animals had known ages and inclusion of the limited age values for this population to the data for the Eastern Chukchi Sea and the Beaufort Sea animals did not result in a significant correlation of any of the elements with age.

\section{MOTHER-FETUS COMPARISONS}

The concentrations of PCBs and chlorinated pesticides in blubber of the near-term fetus (692-BLKA-025) were compared with values for the concentrations of these compounds in the blubber of the mother beluga whale (692-BLKA-024) to determine what compounds might be preferentially transferred from the mother to the fetus during gestation. Of the $31 \mathrm{PCB}$ congeners measured, most had either similar or higher concentrations in the adult female. The notable exceptions were PCB 156. PCB 201, PCB 195, PCB 194, PCB 206, and PCB 209 (Fig. 17). These congeners are the most highly chlorinated of those routinely measured in marine mammals by NIST (i.e., octa-, nona-, and decachlorobiphenyl congeners) and generally contribute the smallest fractions to the total $\mathrm{PCB}$ concentrations in marine mammals. Concentrations ranged from 5 to 10 times higher in the fetus blubber than in the blubber of the mother.

The concentration of EDDT was about 1.5 times higher in the blubber of the mother than in that of the fetus. This was primarily due to the much larger concentration of 4,4-DDE and 2,4'DDT in the blubber of the mother (Fig. 18). The concentrations of mirex were basically the same in the two animals. The concentration of $\alpha-\mathrm{HCH}$ was slightly higher in the mother. The greatest differences between the two animals were for HCB, heptachlor epoxide, cis-chlordane, trans-nonachlor, and dieldrin. HCB was 6 times higher and heptachlor epoxide was 12 times higher in the mother than in the fetus. With the exception of heptachlor epoxide, the chlordane compounds were all higher in the fetus than in the mother, some of them substantially higher. Cis-chlordane was 11 and trans-nonachlor 3 times higher in the fetus than in the mother. Dieldrin was five times higher in concentration in the blubber of the fetus.

Concentrations of persistent organic compounds generally occur at higher concentrations in adult males than in adult females. This is due to "offloading" of these compounds from the mothers to the offspring, which takes place two ways - transfer to the fetus during gestation and transfer to the young after birth via nursing. The values for the fetus shown in Figures 17 and 18 indicate that all of the compounds measured were transferred from the mother to fetus to some degree and that there are relative differences in the magnitude of transfer for each compound. The rate of transfer may vary and may be selective based on the chemical characteristics of the particular compound and the physiology of the animal. At least for this mother-fetus pair, it appears that the more highly chlorinated PCB congeners, most of the chlordane compounds, and dieldrin were preferentially transferred to the fetus.

Concentrations of elements and methylmercury in the liver and kidneys of the fetus and its mother are presented in Table 9. One would expect the electrolyte concentrations (sodium, magnesium, chlorine, and potassium) to be similar for the fetus and the mother and from the values shown in Table 9 this seems to be the case. Also, the concentrations of vanadium, zinc, bromine, and cesium were similar between the two animals. The following elements were higher in the mother than in the fetus: manganese, cobalt, selenium, total mercury, and methylmercury. Copper and rubidium were higher in the fetus.

Manganese was much higher in the liver and kidney of the mother than in the fetus and cobalt was higher in the kidney of the mother than in that of the fetus (no cobalt value is available for the fetus liver). Mercury 


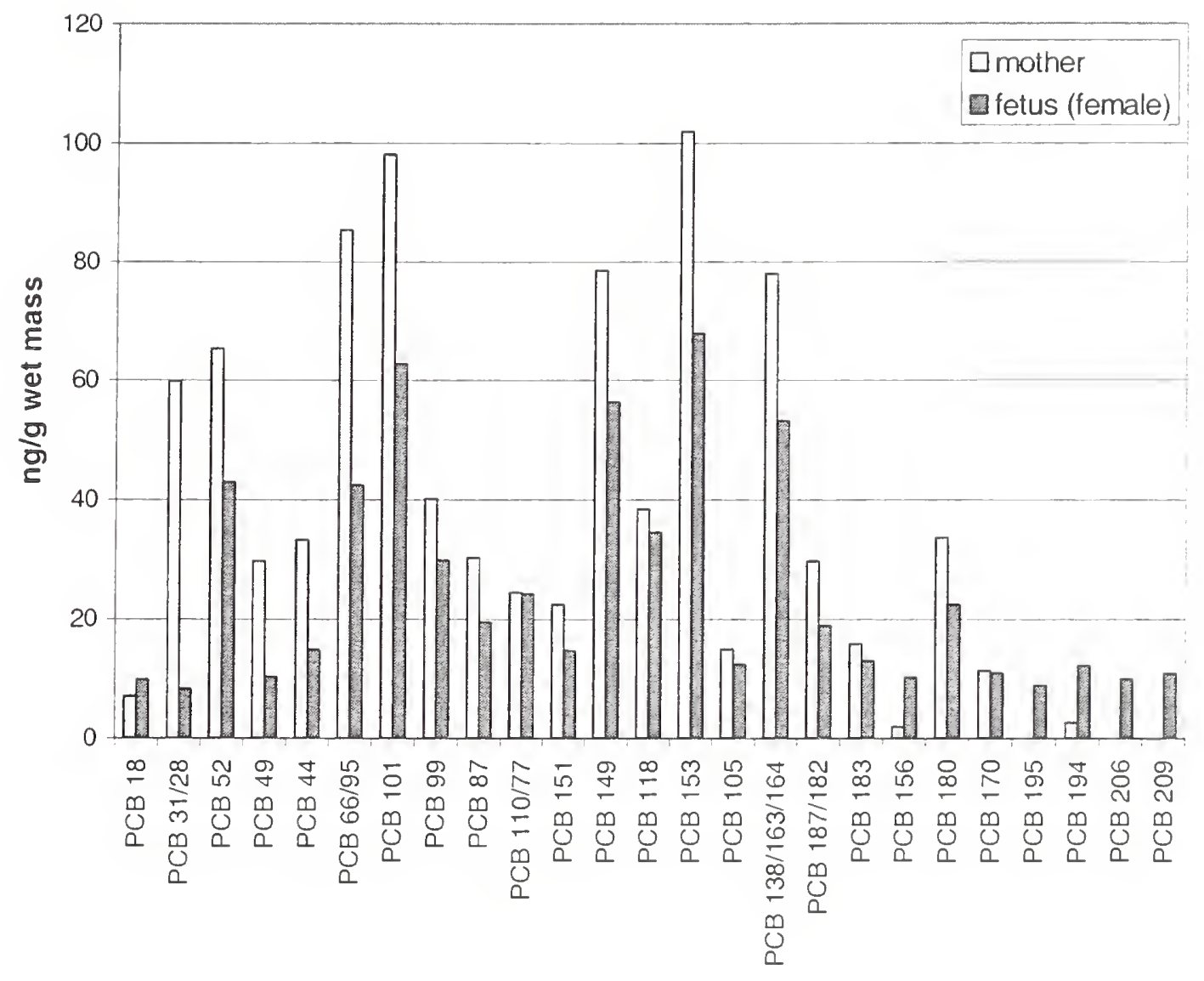

Figure 17. Concentrations of PCB congeners in blubber of a female beluga whale from Cook Inlet and her near-term fetus. 


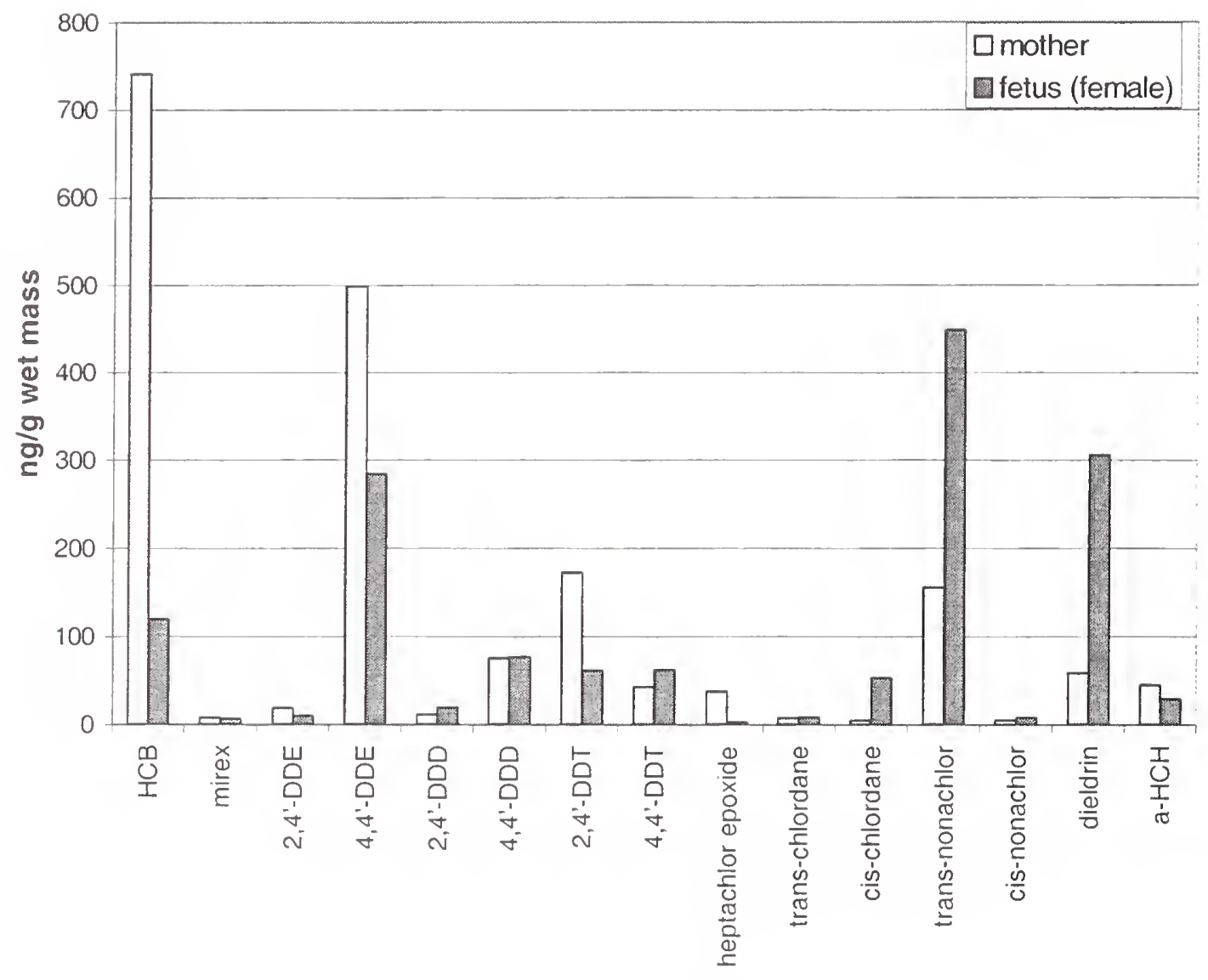

Figure 18. Concentrations of chlorinated pesticides in blubber of a female beluga whale from Cook Inlet and her near-term fetus. 
Table 9. Concentrations of selected elements in livers and kidneys of a female beluga whale from Cook Inlet and her near-term fetus. Values are $\mathrm{mg} / \mathrm{kg}$, wet mass.

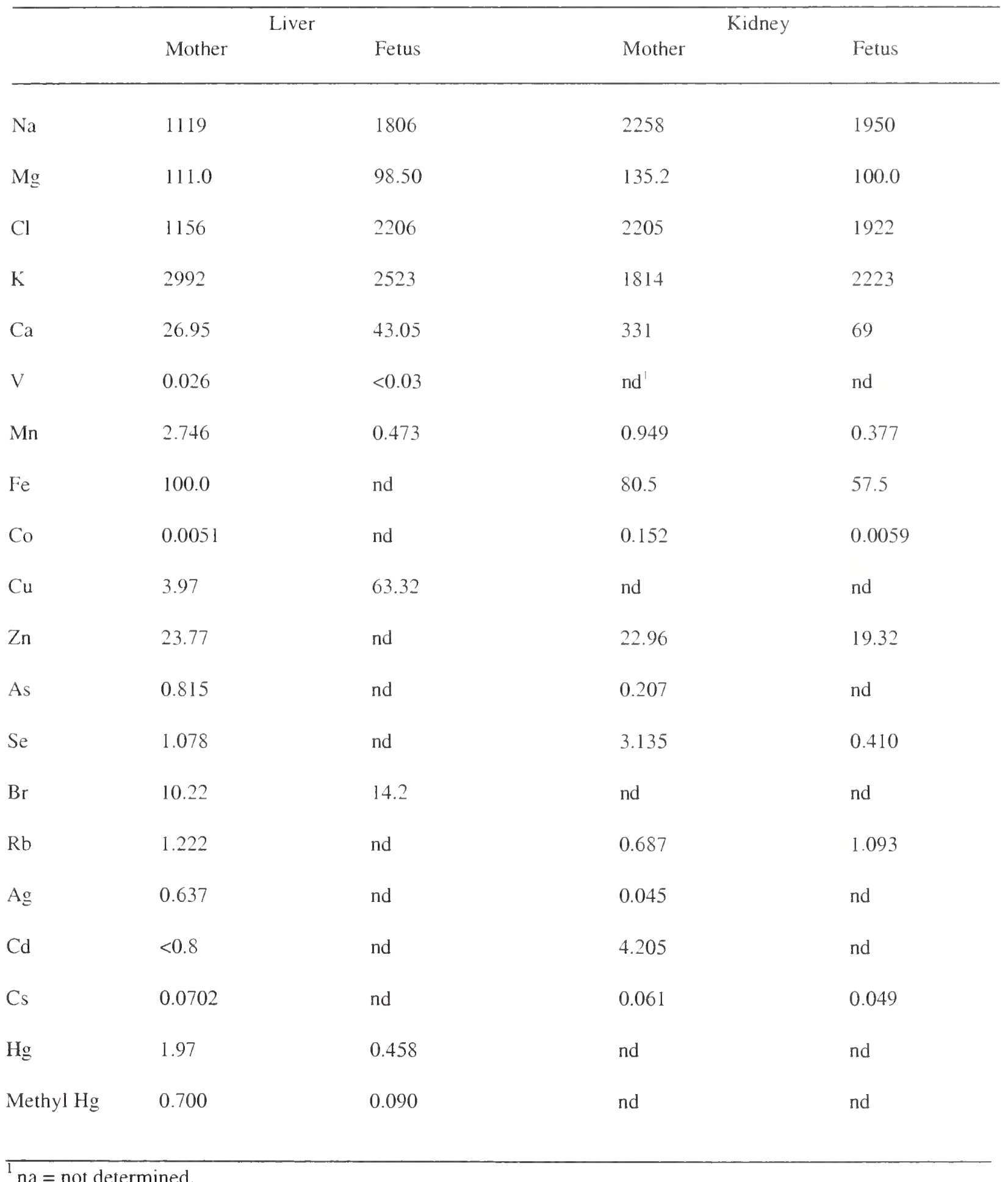


was almost an order of magnitude higher in the liver of the mother than in the fetus, with similar contribution of methylmercury to the total amount (36\% in the mother and $20 \%$ in the fetus). These relative differences suggest the degree of transfer to the young before birth. Although no selenium values are available for the fetus liver, this element was about an order of magnitude higher in the mother's kidney than in the fetus' kidney. Because selenium and mercury are usually positively correlated in liver tissue, one might assume that the selenium value for the fetus liver was probably substantially lower than that for the mother.

Rubidium was higher in the kidney of the fetus than in that of the mother (no rubidium value is available for the fetus liver) and copper was almost an order of magnitude higher in the liver of the fetus than in that of the mother. As mentioned earlier, the highest hepatic copper concentrations are usually found in young animals. The fetus-mother comparison presented here suggests that this pattern of high hepatic copper concentration is established before birth during the development of the fetus.

The calcium concentration was higher in the fetus liver than in the liver of the mother; however, the concentration of this element was much higher in the kidney of the mother than in the kidney of the fetus. This female was one of several adult beluga whales from Cook Inlet exhibiting parasitism by Crassicauda $s p$. with its associated calicifications, which might be reflected in the high calcium levels in the kidneys of this animal.

\section{CONCLUSIONS}

The concentrations of persistent chlorinated compounds were higher in the Cook Inlet males than in the females of this population; however, the relative difference was much less than for the other two Alaskan stocks (Beaufort Sea and Eastern Chukchi Sea). The Cook Inlet animals had much lower concentrations of PCBs and chlorinated pesticides than those which have been reported for the Beaufort Sea and Eastern Chukchi Sea stocks. As compared to the other persistent chlorinated compounds, chlordane compounds contributed substantially less to the total burden in the Cook Inlet beluga whales than it did to the burden of any of the other beluga whale stocks. Such differences for the Cook Inlet animals suggest different sources of these compounds, which may be related to geographic and latitudinal differences in atmosphere transport patterns and processes, geochemical source differences, or different feeding habits or prey availability for these animals.

In the case of heavy metals and other elements, cadmium, mercury, selenium, vanadium, and silver were generally lower in the livers of Cook Inlet animals than in the other beluga whale stocks while copper was higher. Hepatic methylmercury levels were similar to those reported for other beluga whales and did not exceed $2.11 \mathrm{mg} / \mathrm{kg}$ wet mass. The silver, selenium, and mercury relationship previously described for other beluga whale stocks and for pilot whales was also found in the Cook Inlet population. The relatively high hepatic concentration of silver, described previously for the Eastern Chukchi Sea and Beaufort Sea stocks, was also found in the Cook Inlet animals, suggesting a species-specific phenomenon.

A comparison of concentrations of persistent chlorinated compounds and elements in a female beluga whale and in her near-term fetus indicates that all substances measured in the tissues were transferred from the mother to the fetus. However, the relative differences in the concentrations between mother and fetus suggest that the degree of transfer is probably selective based on the chemical characteristics of the particular compound or element and the physiology of the animal. A few of the more highly chlorinated PCB congeners, most of the chlordane compounds, and dieldrin appeared to be preferentially transferred to the fetus. The higher hepatic copper levels in the fetus also suggest that the pattern of relatively high copper 
concentrations in the liver of Cook Inlet beluga whales may be well established before birth during fetal development.

Due to the lower concentrations in the Cook Inlet beluga whales, the effects of PCBs and chlorinated pesticides on animal health may be of less significance for the Cook Inlet animals than for the other beluga whale stocks. However, very little is known about the role that multiple stressors play in the health of individual animals and populations. Biotoxins, bacterial or viral infections, physical stresses in the environment, parasites, periodic limitations in food, or stress of being hunted in combination with the accumulation of toxic chemicals may further compromise animal health. The interaction of such stressors on a declining population, such as the Cook Inlet beluga whales, and the resulting effects on population recruitment should be a major avenue of future research and evaluation.

\section{REFERENCES}

Aquilar, A., Relationship of DDE/DDT in marine mammals to the chronology of DDT input into the Ecosystem, Can. J. Fish. Aquat. Sci. 41(6), 840-844 (1984)

Barrie, L. A., D. Gregor, B. Hargave, R. Lake, D. Muir, R. Shearer, B. Tracey, and T. Bidlemann, Arctic contaminants: sources, occurrence and pathways, Sci. Total Environ. 122, 1-74 (1992).

Becker, P. R., B. J. Koster, S. A. Wise, and R. Zeisler, Biological specimen banking in Arctic research: an Alaska perspective. Sci. Total Environ. 139/140, 69-95 (1993).

Becker, P. R., M. M. Krahn, E. A. Mackey, R. Demiralp. M. M. Schantz, M. Epstein, M. K. Donais, B. Porter, D. C. G. Muir, and S. A. Wise, Concentrations of polychlorinated biphenyls (PCBs), chlorinated pesticides, and heavy metals and other elements in tissues of beluga whales (Delphinapterus leucas) from Cook Inlet, Alaska, Mar. Fish. Rev. (in press).

Becker, P. R., E. A. Mackey, R. Demiralp, M. M. Schantz, B. J. Koster, and S. A. Wise, Concentrations of chlorinated hydrocarbons and trace elements in marine mammal tissues archived in the U.S. National Biomonitoring Specimen Bank, Chemosphere 34, 2067-2098 (1997a).

Becker. P. R. E. A. Mackey, R. Demiralp, R. Suydam, G. Early, B. J. Koster and S. A. Wise, Relationship of silver to selenium and mercury in the liver tissue of two species of toothed whales (odontocetes), Mar. Poll. Bull. 30, 262-271 (1995a).

Becker, P. R., E. A. Mackey, M. M. Schantz, R. R. Greenberg, B. J. Koster, S. A. Wise and D. C. G. Muir, Concentrations of Chlorinated Hydrocarbons, Heavy Metals and Other Elements in Tissues Banked by the Alaska Marine Mammal Tissue Archival Project, NISTIR 5620, National Institute of Standards and Technology, Gaithersburg, Maryland (1995b)

Becker, P. R., B .J. Porter, E. A. Mackey, M. M. Schantz, R. Demiralp, and S. A. Wise, National Marine Mammal Tissue Bank and Quality Assurance Program: Protocols, Inventory, and Analytical Results, NISTIR 6279, National Institute of Standards and Technology, Gaithersburg, Maryland (1999). 
Becker, P. R., D. Wilkinson, and T. I. Lillestolen, Marine Mammal Health and Stranding Response Program: Program Development Plan, NOAA Tech. Memo. NMFS-OPR-94-2, National Oceanic Atmospheric Administration, Silver Spring, Maryland (1994).

Becker, P. R., S. A. Wise, B. J. Koster and R. Zeisler, Alaskan Marine Mammal Tissue Archival Project: a Project Description Including Collection Protocols, NBSIR 88-3750, National Bureau of Standards, Gaithersburg, Maryland (1988).

Becker, P. R., S. A. Wise, B. J. Koster and R. Zeisler, Alaska Marine Mammal Tissue Archival Project: revised collection protocol, NISTIR 4529, National Institute of Standards and Technology, Gaithersburg, Maryland (1991).

Becker, P. R., S. A. Wise, M. M. Schantz, B. J. Koster, and R. Zeisler, Alaska Marine Mammal Tissue Archival Project: Sample Inventory and Results of Analyses of Selected Samples for Organic Compounds and Trace Elements, NISTIR 4731, National Institute of Standards and Technology, Gaithersburg, Maryland (1992).

Becker, P. R., S. A. Wise, L. Thorsteinson, B. J. Koster, and T. Rowles, Specimen banking of marine organisms in the United States: current status and long-term prospective, Chemosphere 34, 1889-1906 (1997b).

Bratton, G. R., C. B. Spainhour, W. Flory, M. Reed, and K. Jayko, Presence and potential effects of contaminants. In: The Bowhead Whale (J. J. Burns, J. J. Montague, and C. J. Cowles, editors), Speciall Publication No. 2, The Society for Marine Mammalogy, Lawrence, Kansas, $701-744$ (1993).

Brodie, P. F, The white whale, Delphinapterus leucas (Pallas, 1776). In: Handbook of Marine Maminals, Volume 4, River Dolphins and the Larger Toothed Whales (S. H. Ridgeway and R. J. Harrison, editors), Academic Press, lnc., New York, 119-143 (1989).

Burns, J. J., and G. A. Seamon, Investigations of Belukha Whales in Coastal Waters of Western and Northern Alaska. II, Biology and Ecology. Final Report, NOAA OCSEAP, Alaska Department of Fish and Game, Contract NA-81-RAC-00049, Fairbanks, Alaska (1986).

Calkins, D., Marine Mammals of Lower Cook Inlet and the Potential for Impact from Outer Continental Shelf Oil and Gas Exploration, Development and Transport, NOAA, OCSEAP, Final Report 20, U.S. Department of Commerce, National Oceanic and Atmospheric Administration, Juneau, Alaska, 171-265 (1983).

Calkins, D. G., Marine mammals. In: The Gulf of Alaska: Physical Environment and Biological Resources (D. W. Hood and S. T. Zimmerman, editors), OCS Study, MMS 86-0095, U.S. Department of Commerce, Minerals Management Service, Anchorage, Alaska, 527-557, (1987).

Calkins, D. G. and K. W. Pitcher, Unusual sightings of marine mammals in the Gulf of Alaska (Abstract). Proceedings of the Second Conference on the Biology of Marine Mammals. San Diego, California, p 53 (1977).

Dietz, R., C. O. Nielsen, M. M. Hansen, and C. T. Hansen, Organic mercury in Greenland birds and mammals, Sci. Total Environ. 95, 41-51 (1990). 
Donais, M. K (Behlke), P. C. Uden, M. M. Schantz, and S. A. Wise, Development, validation, and application of a method for quantification of methylmercury in biological marine materials using gas chromatography atomic emission detection, Anal. Chem. 68, 3859-3866 (1996).

Edmonds, J. S. and K. A. Francesconi, Arsenic in seafoods: human health aspects and regulations, Mar. Poll. Bull. 26(12), 665-674 (1993).

Francesconi, K. A. and J. S. Edmonds, Oceanogr. Mar. Biol. Anmu. Rev. 31, 111 (1993)

Frost, K. and L. Lowry, Distribution, abundance and movements of beluga whales, Delphinapterus leucas, in the coastal waters of western Alaska, Can. Bull. Fish. Aquat. Sci., 224, 39-57 (1990).

Goessler, W., A. Rudorfer, E. A. Mackey, P. R. Becker, and K. J. Irgolic, Determination of arsenic compounds in marine mammals with high-performance liquid chromatography and an inductively coupled plasma mass spectrometer as element-specific detector, Appl. Organometal. Chem. 12, 491-501 (1998).

Hammond, P. B. and R. P. Beliles, Metals. In Casareet and Doull's Toxicology: the Basic Science of Poisons, $2^{\text {nd }}$ edition (J. Doull, C. D. Klaassen, and M.O. Amdur, editors), Macmillan, New York, 409-467 (1980).

Hansen, D. J., and J. D. Hubbard, Distribution of Cook Inlet Beluga Whales (Delphinapterus leucas) in Winter, Final Report, OCS Study, MMS 99-0026, U.S. Department of the Interior, Minerals Management Service, Alaska OCS Region, Anchorage, Alaska (1999).

Hansen, C. T., C. O. Nielsen, R. Dietz, and M. M. Hansen, Zinc, cadmium, mercury, and selenium in minke whales, belugas, and narwhals from West Greenland, Polar Biol. 10. 529-539 (1990).

Hazard, K., Beluga whale. In: Selected Marine Mammals of Alaska: Species Accounts with Research and Management Recommendations (J. W. Lentfer, editor), Marine Mammal Commission, Washington, D.C., $195-235(1988)$.

Hill, C. H.. Interaction of vanadate toxicity in chicks, Biol. Trace Elem. Res. 23, 1-23 (1990).

Hill, P. S. and D. P. DeMaster, Alaska Marine Mammal Stock Assessments 1999, National Marine Mammal Laboratory, Alaska Fisheries Science Center, Seattle, Washington (1999).

Honda, K., R. Tatsukawa, K. Itano, N. Miyazaki, and T. Fujiyama, Heavy metal concentrations in muscle, liver and kidney tissue of striped dolphin, Stenella coeruleoalba, and their variations with body length, weight, age and sex. Agric. Biol. Chem. 47, 1219-1228 (1983).

Hubbard, J. D., D. J. Hansen, and B. A. Mahoney, Winter sighting of beluga whales (Delphinapterus leucas) in Yakutat-Disenchantment Bay, Alaska. Arctic 52(4): 411-412 (1999).

Iyengar, G. V. and K. S. Subramanian, Environmental specimen banking and analytical chemistry. In: Environmental Biomonitoring: Exposure Assessment and Specimen Banking (K. S. Subramanian and G. V. Iyengar, editors), ACS Symposium Series 654, American Chemical Society Books, Washington, D.C. 23, 220-245 (1997). 
Iwata, H., S. Tanabe, N. Sakai, A. Nishimura, and R. Tatsukawa, Geographical distribution of persistent organochlorines in air, water and sediments from Asia and Oceania, and their implications for global redistribution from lower latitudes, Environ. Pollut. 85, 15-33 (1994).

Julshamn, K., A. Andersen, O. Ringdal, and J. Morkore, Trace elements intake in the Faroe Islands I. Element levels in edible parts of pilot whales (Globicephala melaenus), Sci. Total Environ. 65, 53-62 (1987.

Koeman, J. H., W. H. M. Peeters, C. H. M. Koudstaal-Hoi, P. Tijioe, and J. de Goeij, Mercury-selenium correlations in marine mammals, Nature 245, 385-386 (1973).

Kleinenberg, S. E., A. V. Yablokov, B. M. Belkovich, and M. N. Tarasevich, Beluga (Delphinapterus leucas) - Investigation of the species. Akad. Nauk SSSR, Moscow. In: Russian, translation by Israel Program for Sci. Transl. Jerusalem. 1969 (1964).

Krahn. M. M., L. K. Moorre, R. G. Bogar, C. A. Wigren, S. - L. Chan, and D. W. Brown, High-performance liquid chromatographic method for isolating organic contaminants from tissue and sediment extracts, $J$. Chromatogr. 437, 161-175 (1988).

Krahn, M. M., D. G. Burrows, J. E. Stein, P. R. Becker, M. M. Schantz, D. C. G. Muir, T. M. O'Hara, and T. Rowles, White whales (Delphinapterus leucas) from three Alaskan Stocks: Concentrations and patterns of persistent organochlorine contaminants in blubber, J. Cetacean Res. Manage. 1(3), 239-249 (1999).

Krone, C. A., P. A. Robisch, K. L. Tilbury, J. E. Stein, E. A. Mackey, P. R. Becker, T. M. O'Hara, and L. M. Philo, Elements in liver tissues of bowhead whales (Balaena mysticetus), Mar. Mam. Sci. 15(1), 123-142 (1999).

Lillestolen, T. I., N. Foster, and S. A. Wise, Development of the National Marine Mammal Tissue Bank, Sci. Total Environ. 139/140, 97-107 (1993).

Mackey, E. A., P. R. Becker, R. Demiralp, R. R. Greenberg, B. J. Koster, and S. A. Wise, Bioaccumulation of vanadium and other trace metals in livers of Alaskan cetaceans and pinnipeds, Arch. Environ. Contamin. Toxicol. 30, 503-512 (1996).

Mackey, E. A., R. Demiralp, P. R. Becker, R. R. Greenberg, B. J. Koster, and S. A. Wise, Trace element concentrations in cetacean liver tissues archived in the National Marine Mammal Specimen Bank, Sci. Total Environ. 175, 25-41 (1995).

Maher, W. A., The presence of arsenobetaine in marine animals, Comp. Biochem. Physiol. 80C, 199-201 (1985).

Meador, J. P., U. Varanasi, P. A. Robisch, and S. - L. Chan, Toxic metals in pilot whales (Globicephala melas) from strandings in 1986 and 1990 on Cape Cod. MA, Can. J. Fish. Aquat. Sci. 50, 2698-2706 (1993).

Moore, S. E. and D. P. DeMaster, The status of Cook Inlet beluga: an overview, Mar. Fish. Rev. (in press).

Muir, D. C. G., R. Wagemann, N. P. Grift, R. J. Norstrom, M. Simon, and J. Lein, Organochlorine chemical and heavy metal contaminants in white-beaked dolphins (Lagenorhynchus albirostris) and pilot whales (Globicephala melaena) from the coast of Newfoundland, Canada, Arch. Environ. Toxicol. Chem. 17,613629 (1988). 
Muir, D., C. Ford, R. Stewart, T. Smith, R. Addison, M. Zinck, and P. Béland, Organochlorine contaminants in belugas, Delphinapterus leucas, from Canadian waters, Can. Bull. Fish. Aquat. Sci. 224,165-190 (1990).

Muir, D., B. Braune, B. DeMarch, R. Norstrom, R. Wagemann, L. Lockhart, B. Hargrave, D. Bright, R. Addison, J. Payne, and K. Reimer, Spatial and temporal trends and effects of contaminants in the Canadian Arctic marine ecosystem: a review, Sci. Total Environ. 230, 83-144 (1999).

Nakata, H., S. Tanabe, R. Tatsukawa, M. Amano, N. Miyazaki, and E. A. Petrov, Bioaccumulation profiles of polychlorinated biphenyls including coplanar congeners and possible toxicological implications in Baikal seal (Phoca sibirica), Environ. Pollut. 95, 57-65 (1997).

Nielsen, F. H. and E. O. Ulthus. The essentiality and metabolism of vanadium. In: Vanadium in Biological Systems (N. D. Chasteen, editor), Kluwer Academic Press, Dordrecht, The Netherlands, 51-62 (1990).

O'Corry-Crowe, G. M.. R. S. Suydam, A. Rosenberg, K. J. Frost, and A. E. Dizon, Phylogeography, population structure and dispersal patterns of the beluga whale, Delphinapterus leucas, in the western Nearctic by mitochondrial DNA, Mol. Ecol. 6, 955-970 (1997).

Ponce, R. A., G. M. Egeland, J. P. Middaugh, and P. R. Becker, Twenty years of trace metal analyses of marine mammals: evaluation and summation of data from Alaska and other Arctic regions, State of Alaska Epidemiology Bulletin 1(3) (1997).

Rugh, D. J., K. E. W. Shelden, and B. Mahoney, Distribution of beluga whales in Cook Inlet. Alaska, during June and July, 1993-1998. Fish. Bull. (in press).

Schantz, M. M., B. J. Koster, S. A. Wise, and P. R. Becker, Determination of PCBs and chlorinated hydrocarbons in marine mammal tissues, Sci. Total Environ. 139/140, 323-345 (1993).

Schantz, M. M., B. J. Koster, L. M. Oakley, S. B. Schiller, and S. A. Wise, Certification of polychlorinated biphenyl congeners and chlorinated pesticides in whale blubber standard reference material, Anal. Chem. 67 , 901-910 (1995).

Seaman, G. A.. K. J. Frost, L. F. Lowry, and J. J. Burns, Investigations of belukha whales in coastal waters of western and northern Alaska, NOAA, OCSEAP, Final Report 56. U.S. Department of Commerce, National Oceanic and Atmospheric Administration, Anchorage, Alaska, 153-39l (1986).

Stern, G. A., D. C. G. Muir, M. D. Segstro, R. Dietz, and M. P. Heide-Jorgensen, PCBs and other organochlorine contaminants in white whales (Delphinapterus leucas) for West Greenland: variations with age and sex, Bioscience 39, 2443-257 (1994).

Stoeker, B. J. and L. L. Hopkins, Vanadium. In: Biochemistry of the Essential Ultratrace Elements (E. Frieden, editor), Plenum Press, New York, 239 - 256 (1984).

Tanabe, S., H. Iwata, and R. Tatsukawa, Global contamination by persistent organochlorines and their ecotoxicological impact on marine mammals, Sci. Total Environ. 154, 163-178 (1994).

Taylor, D. L., S. Schliebe, and H. Metsker, Contaminants in blubber, liver and kidney tissue of Pacific walruses, Mar. Poll. Bull. 20(9), 465-468 (1989). 
Thomson, D. R., Metal Levels in Marine Vertebrates. In: Heavy Metals in the Marine Environment (R. W. Furness and P. S. Rainbow, editors), CRC Press, Inc., Boca Raton, Florida, 143-182 (1990).

Wade, T. L., L. Chambers, P. R. Gardinali, J. L. Sericano, and T. J. Jackson, Toxaphene, PCB, DDT and chlordane analyses of beluga whale blubber, Chemosphere 34, 1351-1357 (1997).

Wagemann, R., N. B. Snow, A. Lutz, and D. P. Scott. Heavy metals in the tissues of the narwhal (Monodon monoceros), Can. J. Fish. Aquat. Sci. 40, 206-214 (1983).

Wagemann, R., R. E. A. Stewart, P. Beland, and C. Desjardins, Heavy metals in tissues of beluga whales from various locations in the Canadian Arctic and the St. Lawrence River. Can. Bull. Fish. Aquat. Sci. 224, 191-206 (1990).

Wagemann, R.. S. Innes, and P. R. Richard, Overview and regional and temporal differences of heavy metals in Arctic whales and ringed seals in the Canadian Arctic, Sci. Total Environ. 186, 41-66 (1996).

Wania, F. and D. Mackay, Global fractionation and cold condensation of low volatility organochlorine compounds in polar regions, Ambio 22, 10-18 (1993).

Warburton, J. and D. J. Seagars, Heavy metal concentrations in liver and kidney tissues of Pacific walrus: continuation of a baseline study, USFWS Tech. Report R7/MMM93-1, Anchorage, Alaska (1993).

Wide, M. Effect of short-term exposure to five industrial metals on the embryonic and fetal development of the mouse, Environ. Res. 33, 47-53 (1984).

Wise, S. A. and B. J. Koster, Considerations in the design of an environmental specimen bank: experiences of the National Biomonitoring Specimen Bank Program, Environ. Health Perspect. 103, 61-67 (1995).

Wise, S. A., M. M. Schantz, B. J. Koster, R. Demiralp, E. A. Mackey, R. R. Greenberg, M. Burow, P. Ostapczuk, and T. I. Lillestolen. Development of frozen whale blubber and liver reference materials for the measurement of organic and inorganic contaminants, Fresenius J. Anal. Chem. 345, 270-277 (1993).

Wrench, J. S., W. Fowler, and M. Y. Ünlü, Arsenic metabolism in a marine food chain, Mar. Poll. Bull. 10(1), 18-20 (1979).

Zeisler, R., J. K. Langland, and S. H. Harrison, Cryogenic homogenization procedure for biological tissues, Anal. Chem. 60, 2760-2765 (1983). 


\section{APPENDIX: ANALYTICAL DATA}

Table A. PCb Congeners: Beluga Whale Blubber From NIST Report of Analysis 839.02-96-008

Table B. Chlorinated Pesticides: Beluga Whale Blubier From NIST Report of Analysis 839.02-96-008

Table C. Elements: Beluga Wiale Livers and Kidneys From NIST Reports of Analysis 93/834/NUCLM/379 $94 / 834 / \mathrm{NUCLM} / 258$

839.02-96-003 839.05-97-002 839.05-97-005 839.05-97-019 839.05-97-027 839.01-98-026

Table D. Ratios of Dry to Wet Mass: Beluga Whale Livers and Kidneys From NIST Reports of Analysis 93/834/NUCLM/379 94/834/NUCLM/258

839.05-97-002

839.05-97-005

839.05-97-019

839.05-97-027 


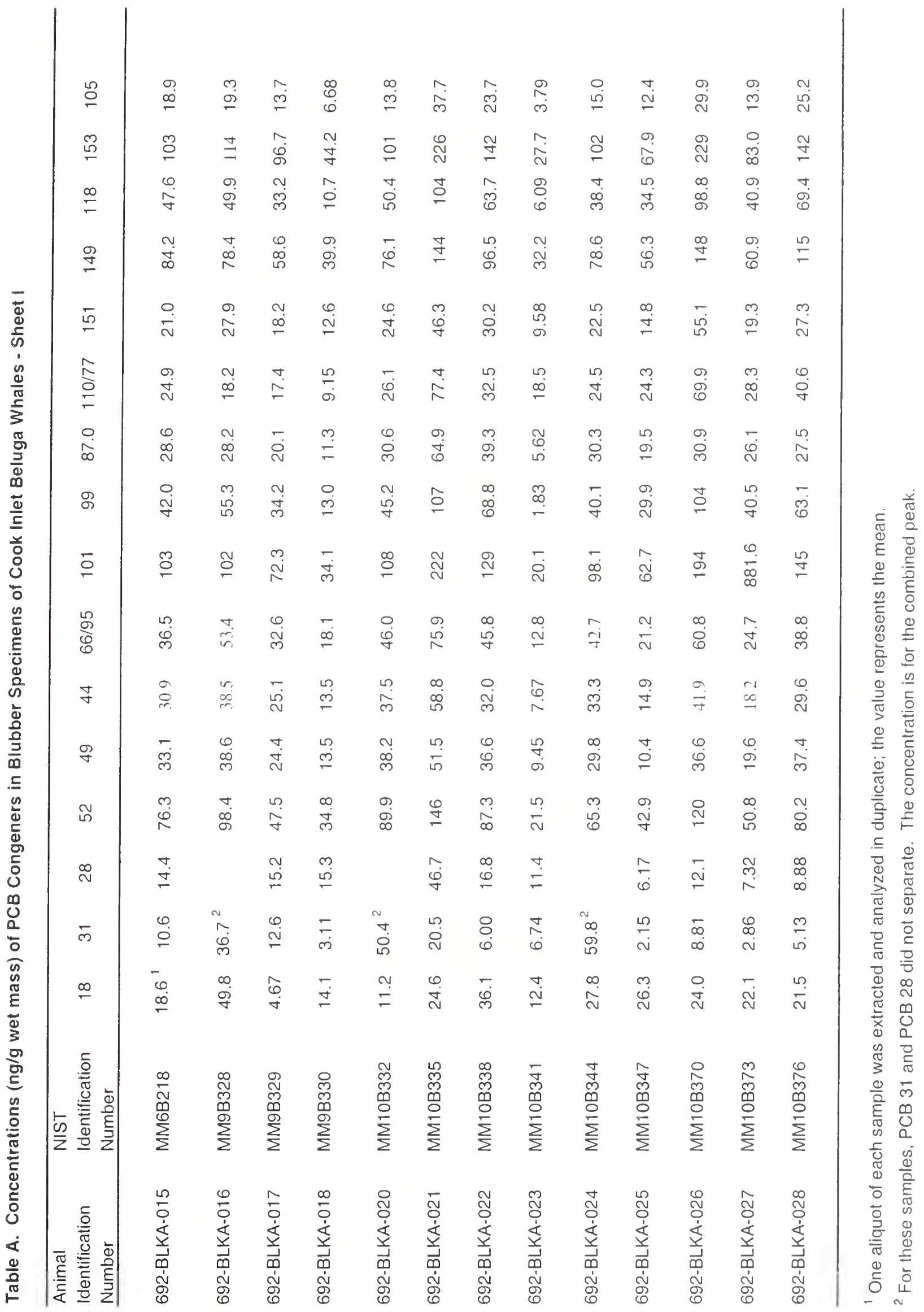




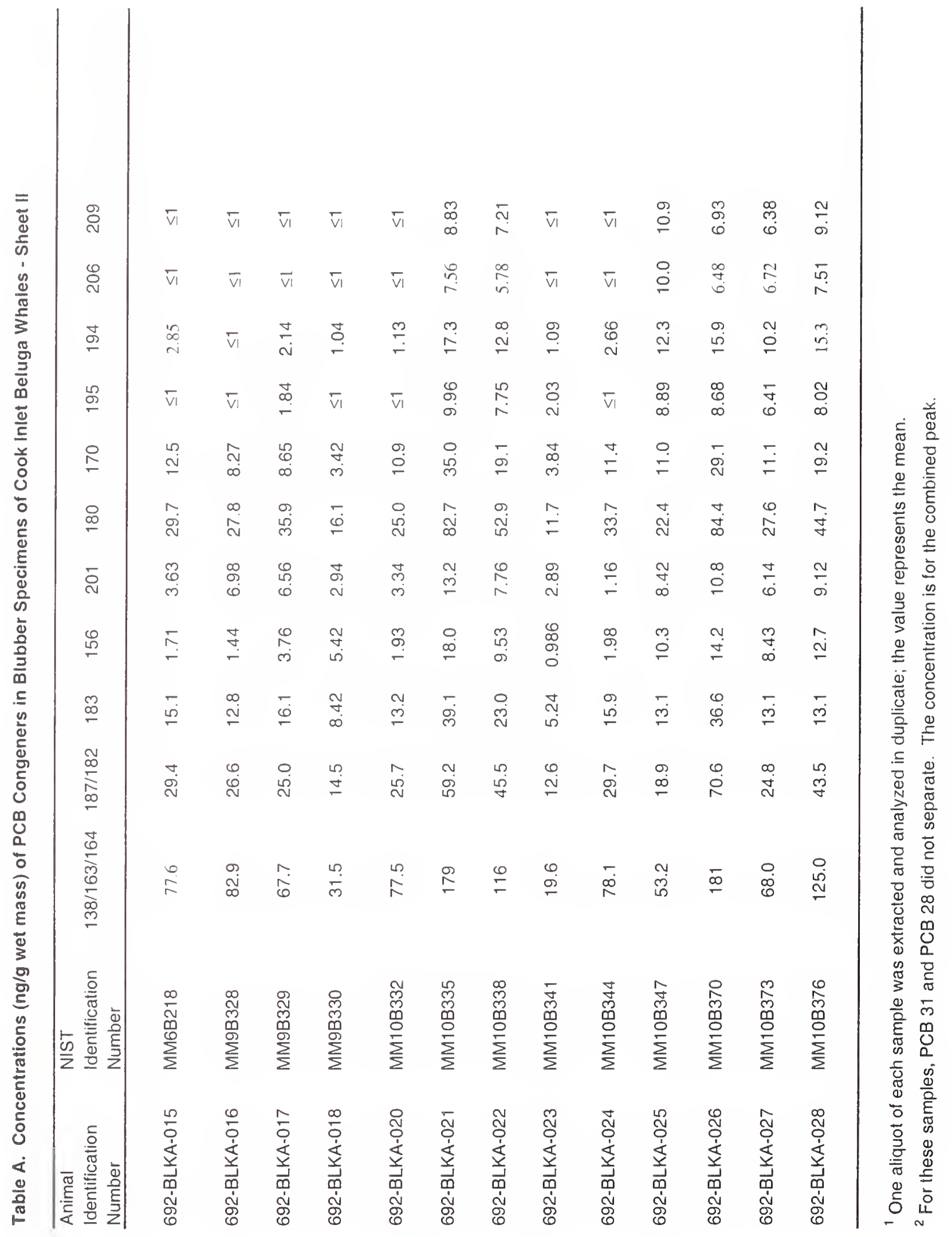




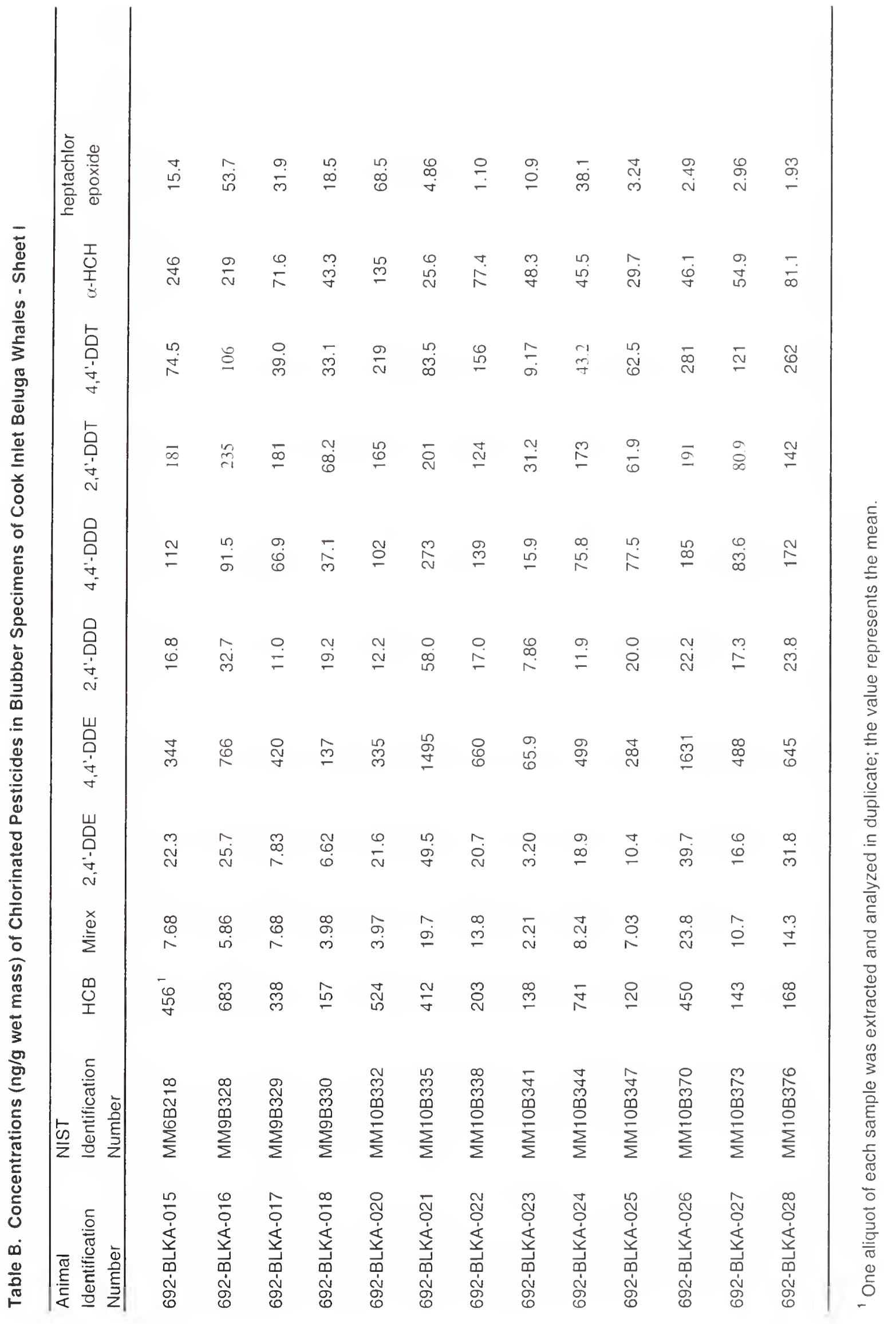




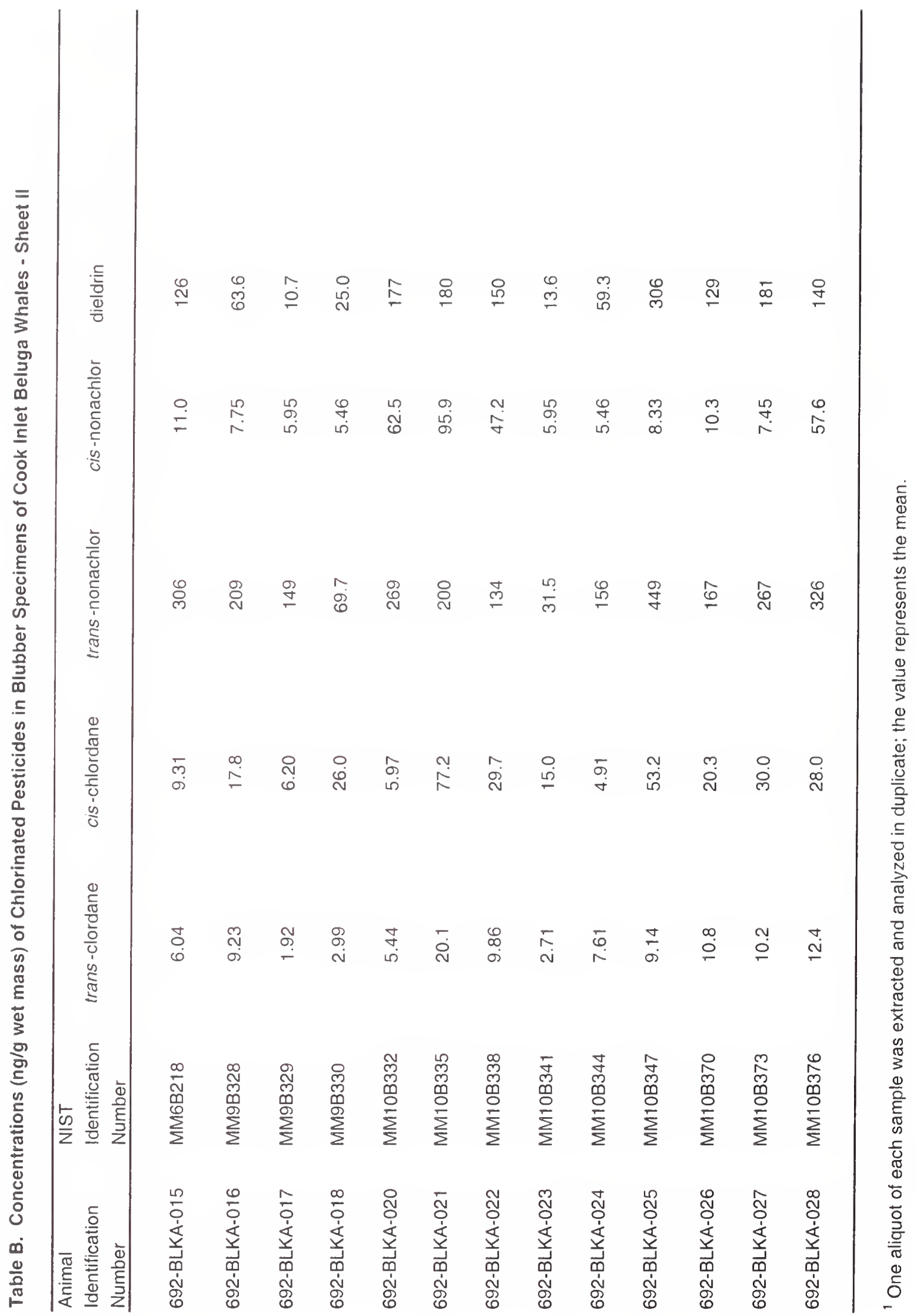




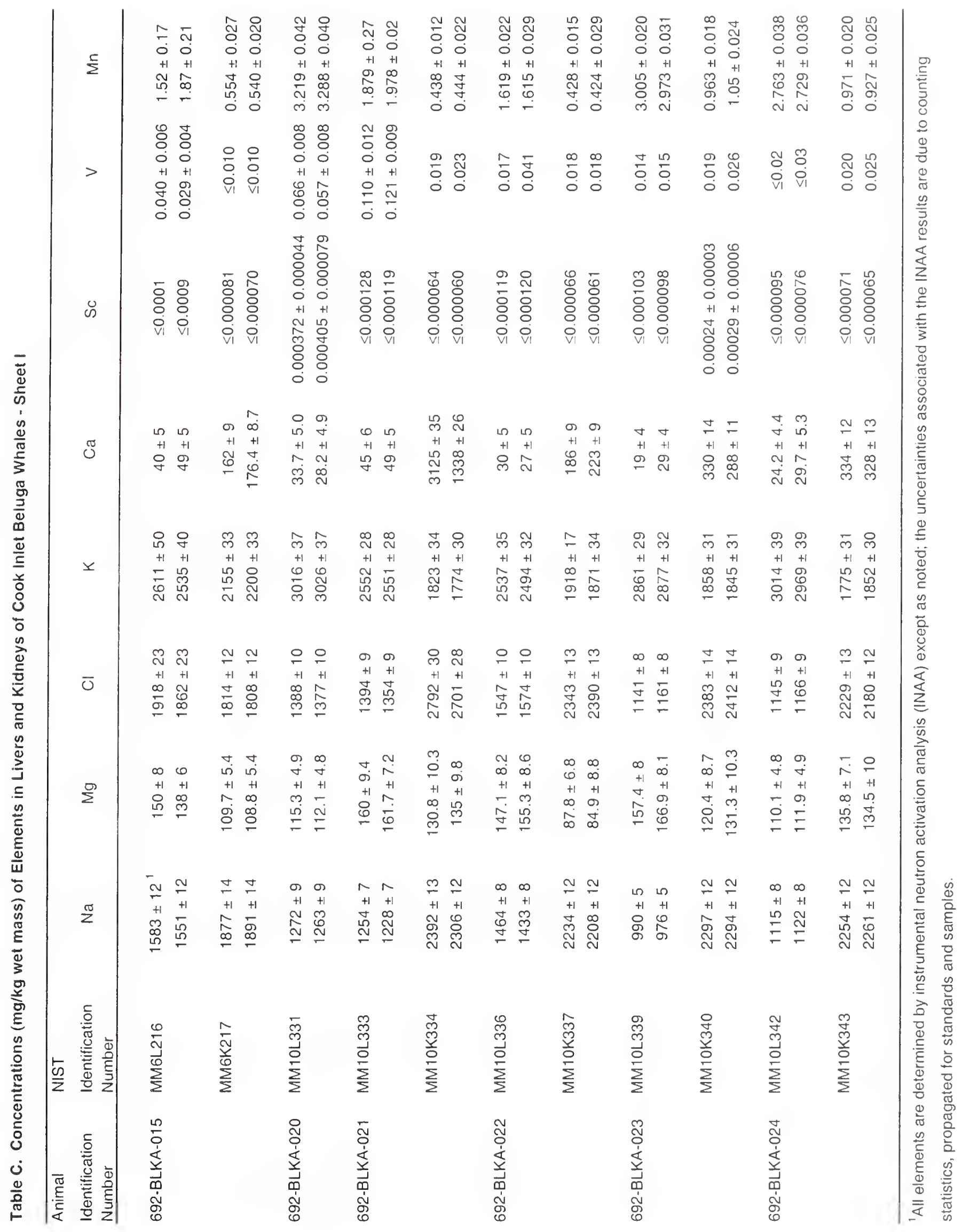




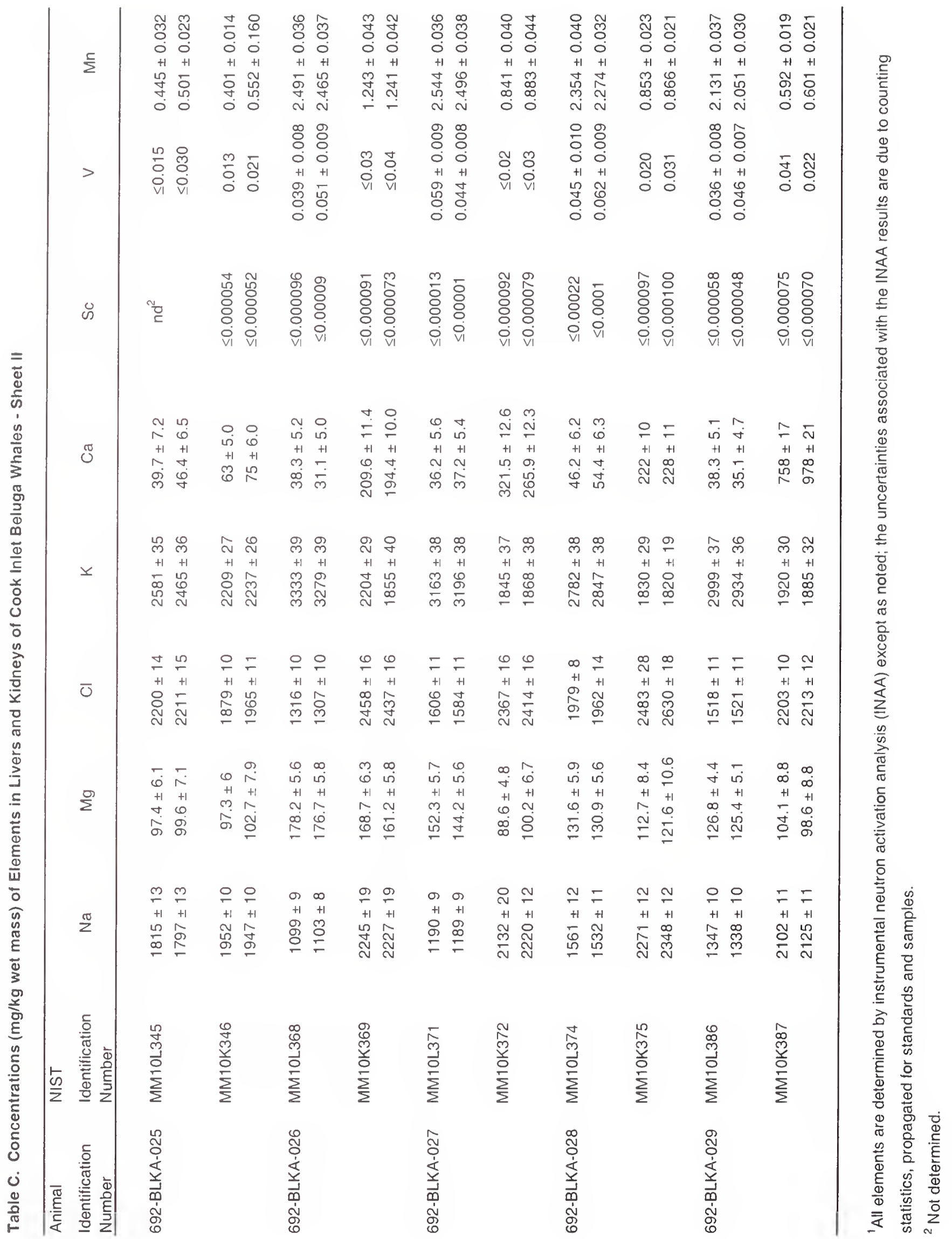




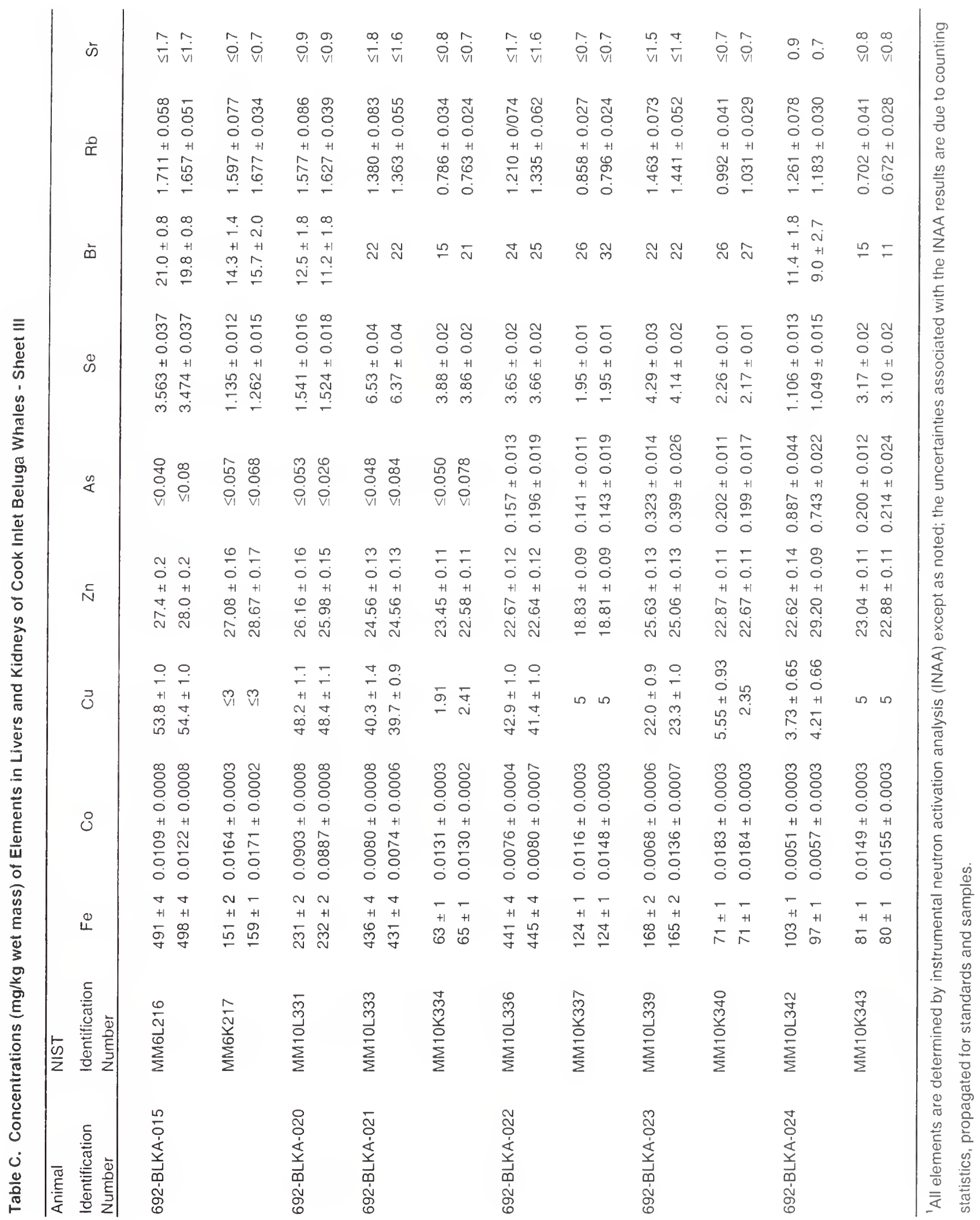




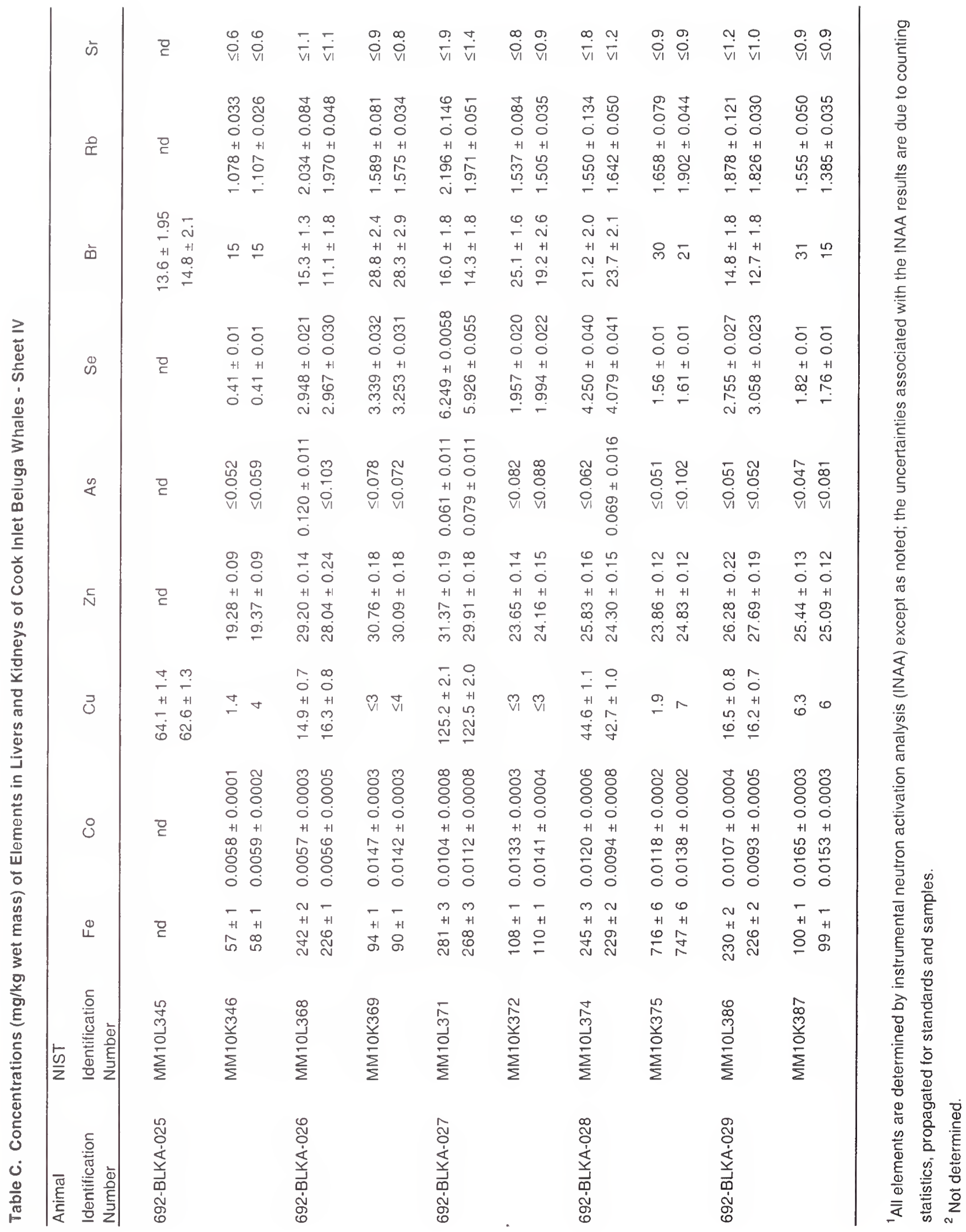




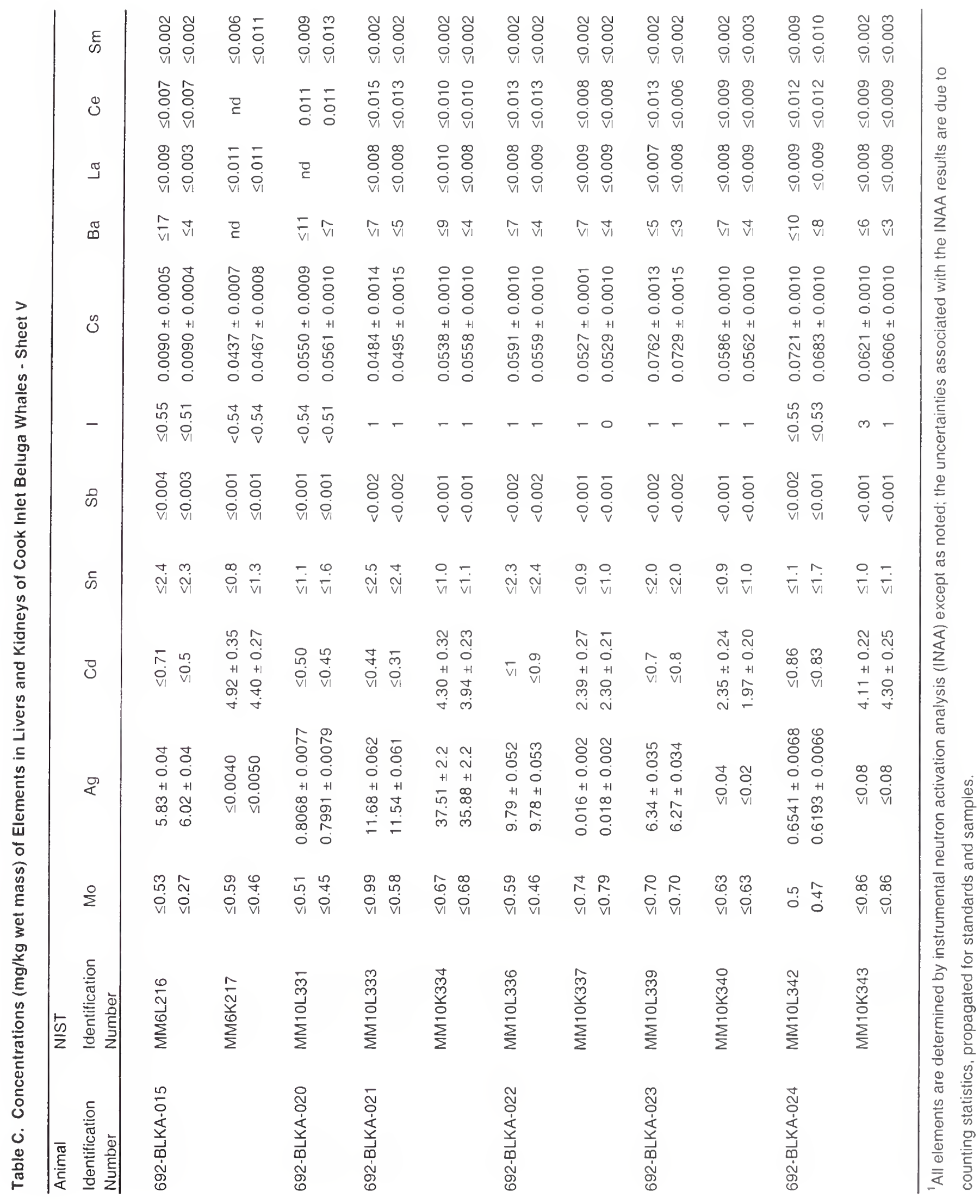




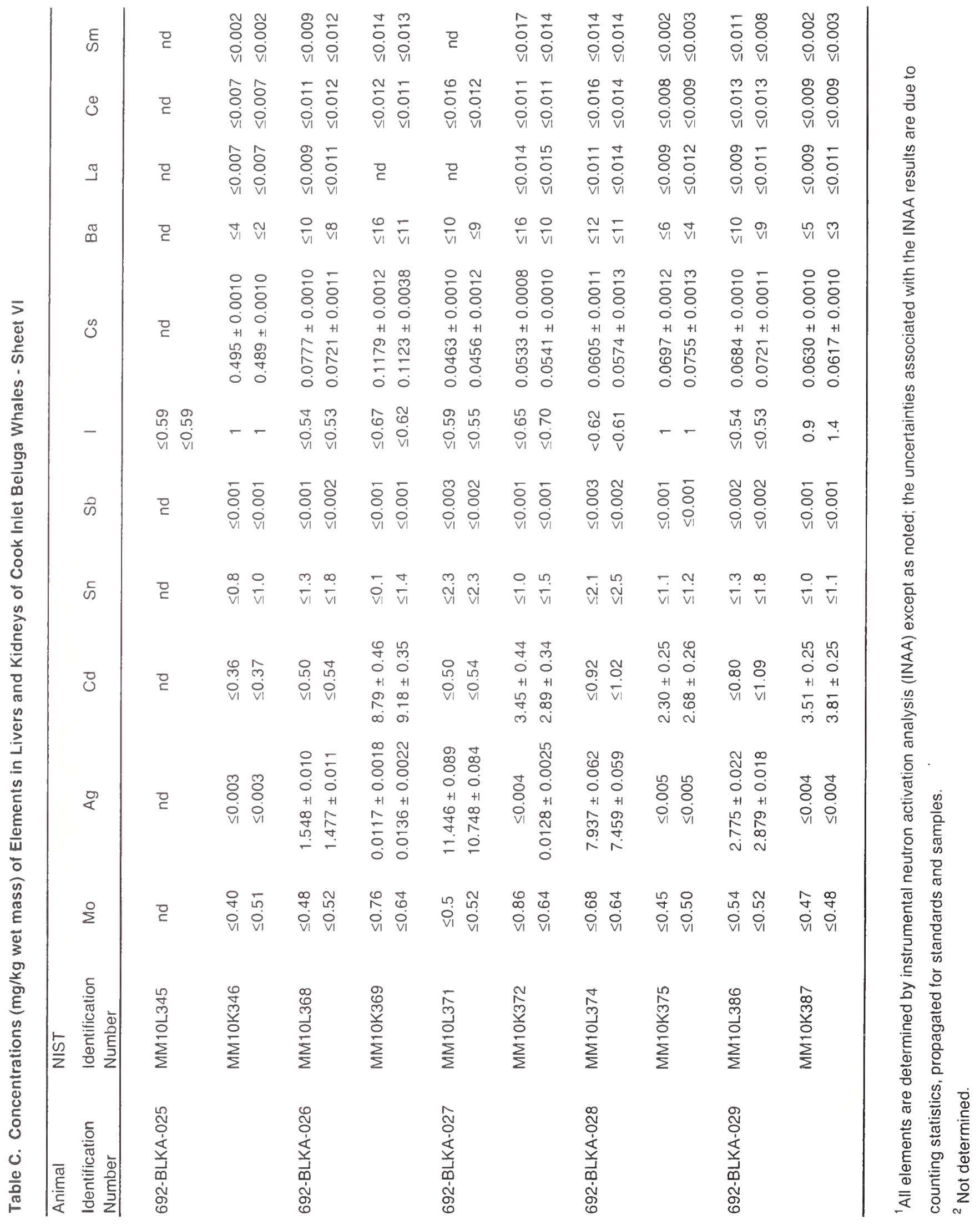




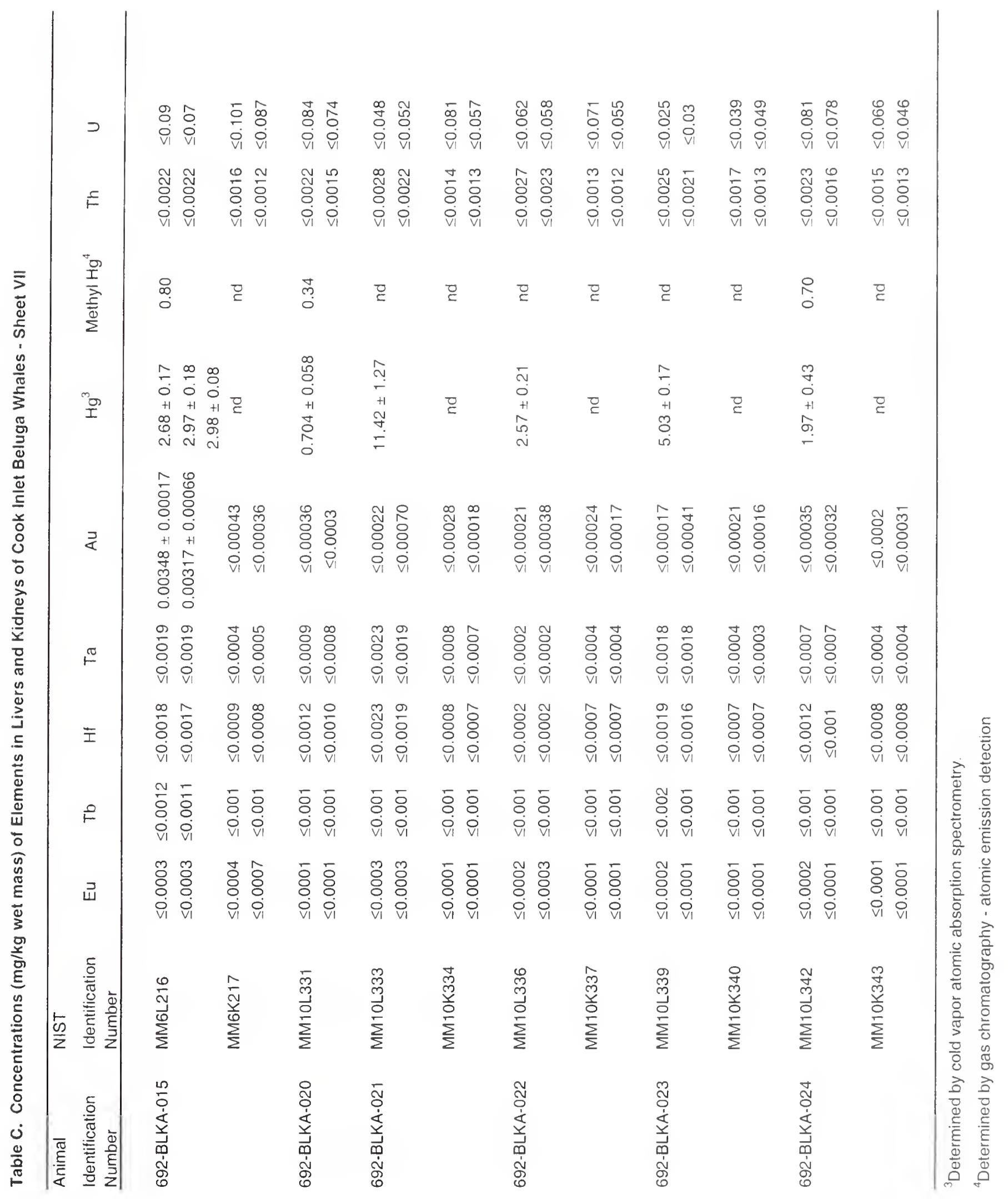




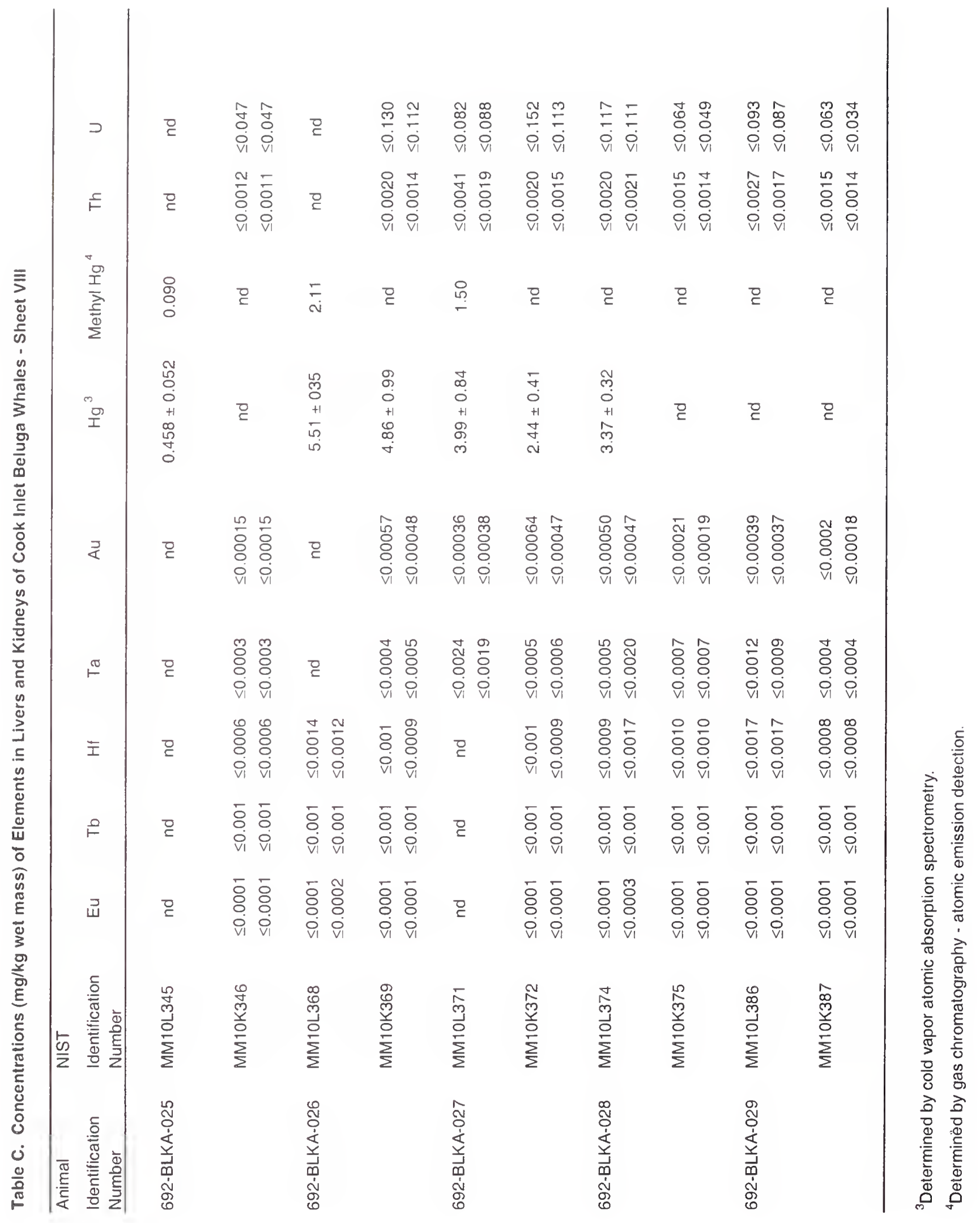


Table D. Ratio of Dry to Wet Mass in Livers and Kidneys of Cook Inlet Beluga Whales

\begin{tabular}{|c|c|c|}
\hline $\begin{array}{l}\text { Animal } \\
\text { Identification } \\
\text { Number }\end{array}$ & $\begin{array}{l}\text { NIST } \\
\text { Identification } \\
\text { Number }\end{array}$ & $\begin{array}{c}\text { Ratio of } \\
\text { Dry to Wet } \\
\text { Mass }\end{array}$ \\
\hline 692-BLKA-015 & $\begin{array}{l}\text { MM6L216 } \\
\text { MM6K217 }\end{array}$ & $\begin{array}{l}0.2562 \\
0.2102\end{array}$ \\
\hline 692-BLKA-020 & MM10L331 & 0.2359 \\
\hline 692-BLKA-021 & $\begin{array}{l}\text { MM10L333 } \\
\text { MM10K334 }\end{array}$ & $\begin{array}{l}0.2392 \\
0.1895\end{array}$ \\
\hline 692-BLKA-022 & $\begin{array}{l}\text { MM10L336 } \\
\text { MM10K337 }\end{array}$ & $\begin{array}{c}0.2539 \\
0.215\end{array}$ \\
\hline 692-BLKA-023 & $\begin{array}{l}\text { MM10L339 } \\
\text { MM10K340 }\end{array}$ & $\begin{array}{l}0.2801 \\
0.2033\end{array}$ \\
\hline 692-BLKA-024 & $\begin{array}{l}\text { MM10L342 } \\
\text { MM10K343 }\end{array}$ & $\begin{array}{l}0.2796 \\
0.2203\end{array}$ \\
\hline 692-BLKA-025 & $\begin{array}{l}\text { MM10L345 } \\
\text { MM10K346 }\end{array}$ & $\begin{array}{l}0.2148 \\
0.1611\end{array}$ \\
\hline 692-BLKA-026 & $\begin{array}{l}\text { MM10L368 } \\
\text { MM10K369 }\end{array}$ & $\begin{array}{l}0.2696 \\
0.2242\end{array}$ \\
\hline 692-BLKA-027 & $\begin{array}{l}\text { MM10L371 } \\
\text { MM10K372 }\end{array}$ & $\begin{array}{l}0.2586 \\
0.2446\end{array}$ \\
\hline 692-BLKA-028 & $\begin{array}{l}\text { MM10L374 } \\
\text { MM10K375 }\end{array}$ & $\begin{array}{l}0.2568 \\
0.2043\end{array}$ \\
\hline 692-BLKA-029 & $\begin{array}{l}\text { MM10L386 } \\
\text { MM10K387 }\end{array}$ & $\begin{array}{l}0.2449 \\
0.2304\end{array}$ \\
\hline
\end{tabular}






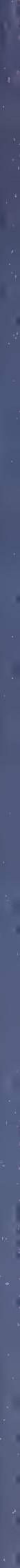

